\title{
العلاقات العراقية-التركية
}

$r \cdot I r-r \ldots r$

د. لقمان عمر محمود النعيمي

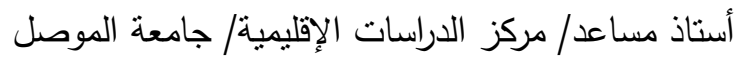

\section{مستخلص البحث}

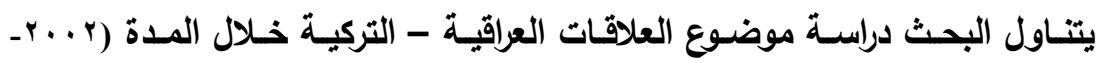

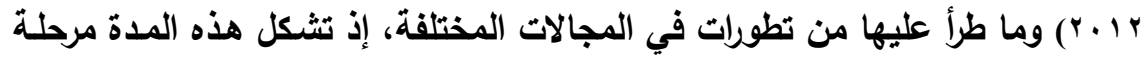

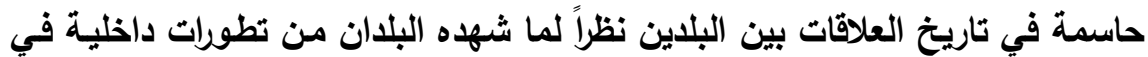

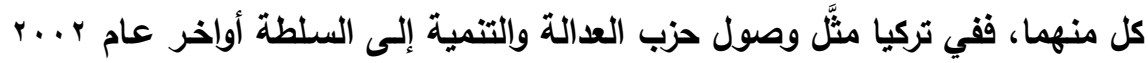

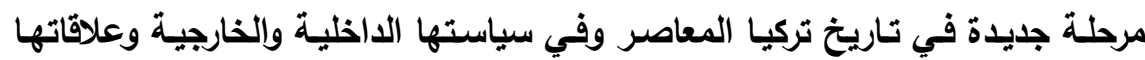

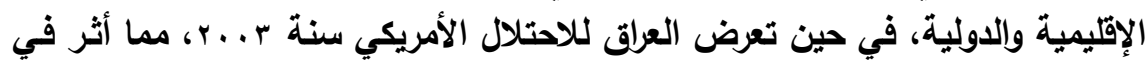

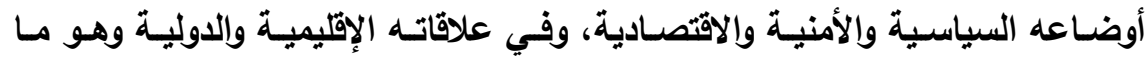
انعكس على العلاقات الثنائية بين البلاين.

\section{مقدمة}

شـهدت كل من تركيا والعراق حدثنان مهمـان في مطلـع القرن الحـادي

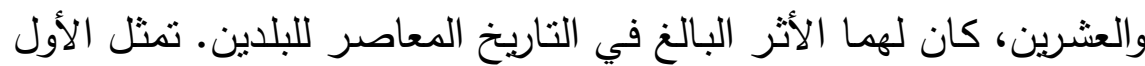
بوصول حزب العدالة والتتمية إلى السلطة في تركيا بعد فوزه بالانتخابات

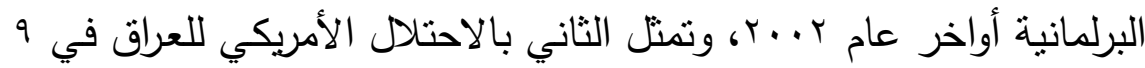
نيسان/ ابريل r ...r، وما تمخض عنه من تداعيات داخلية وإقليمية ودولية؛

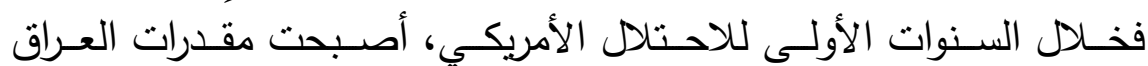
السياسية والأمنية والاقتصـادية بيد الولايات المتحدة، وأصبح لزاماً على أية الهية

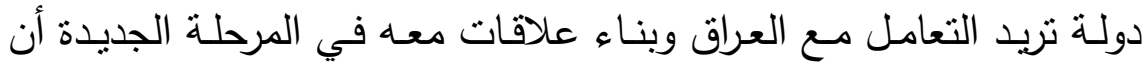

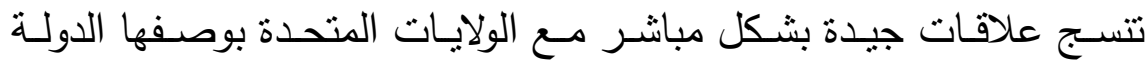




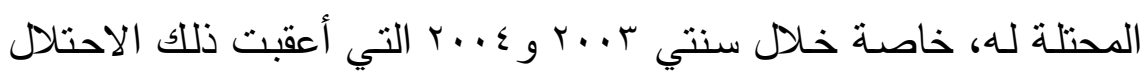

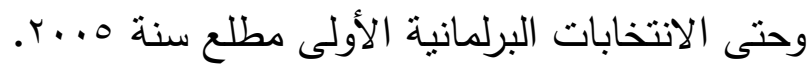
بعد التوتز الذي شاب العلاقات التركية- الأمريكية عقب رفض التض التبة البرلمان

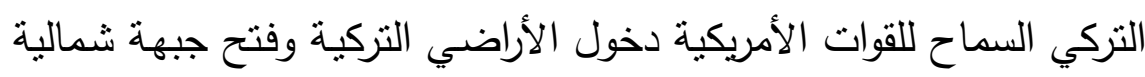

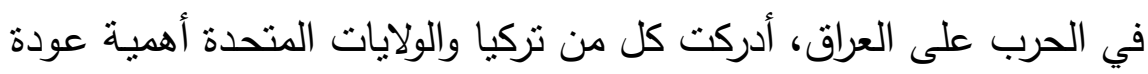

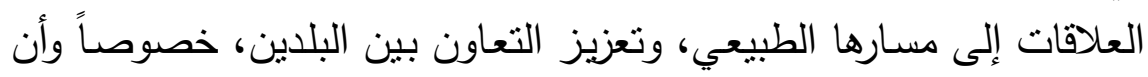

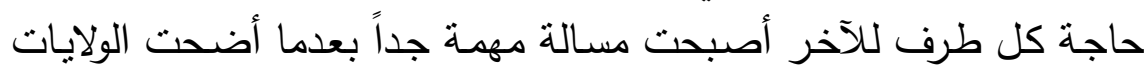
المتحدة جارة لتركيا عقب احتلالها للعراق. لهذا السبب أدركت الحكومة التركية أهمية المبادرة بإعادة علاقات تركيا

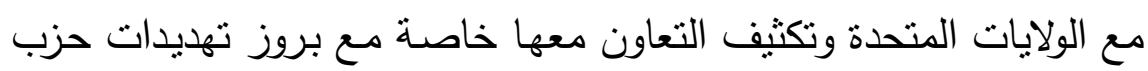

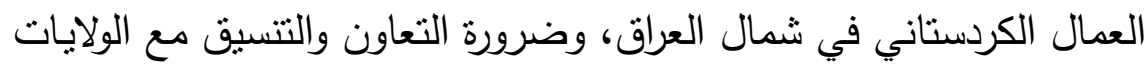

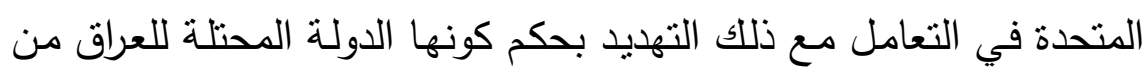
جهة، وقدرتها على التأثير في حلفائها الأكراد العراقيين في التعاون مع نركيا في حل مشكلة حزب العمال الكردستاني من جهة أخرى.

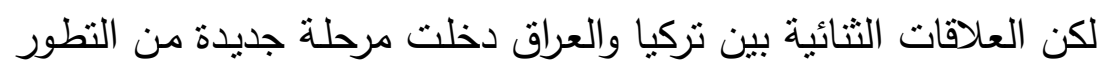

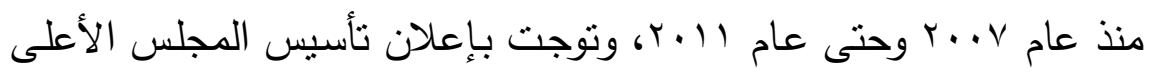

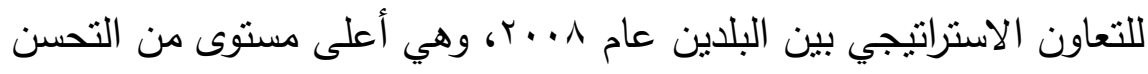

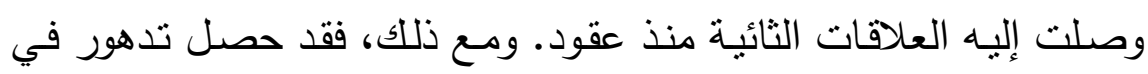

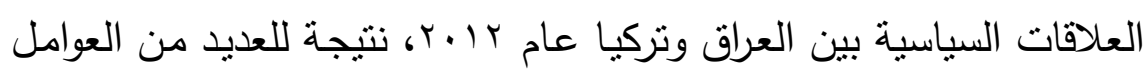

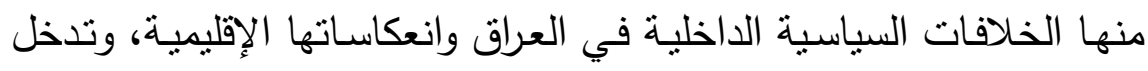
دول الجوار في الثؤون الداخلية للعراق، فضلا عن اختلاف موقف البلدين من الثورة السورية، الأمر الذي انعكس سلباً على العلاقات بينهما.

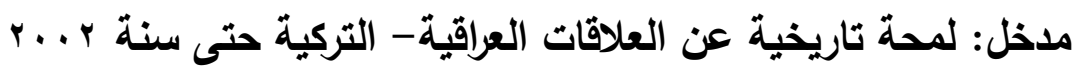


بعد تشكيل الدولة العراقية الحديثة عام ابو ا، اتضـح بأن تركيا لم تنسن

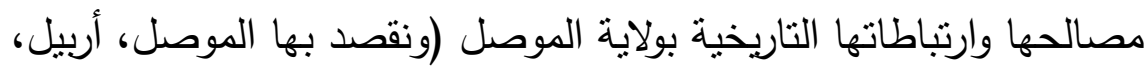

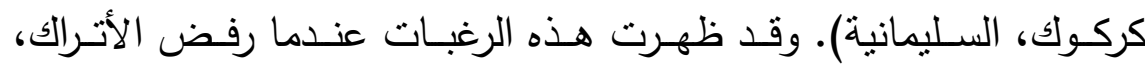
الاعتراف بالدولة العراقية وطالبوا بولاية الموصل وأكدوا في ميثاقهم الوطني

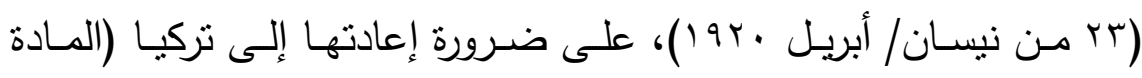
الأولى من الميثاق). وقد قامت وجهة نظر واضعي الميثاق على أن أغلبية

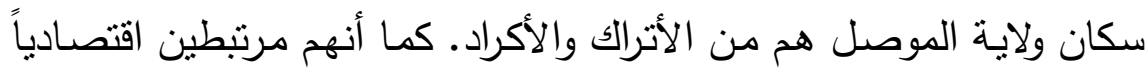

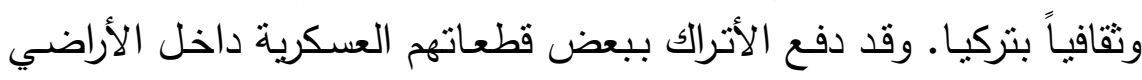

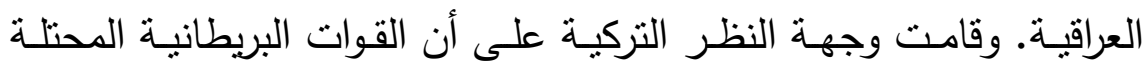

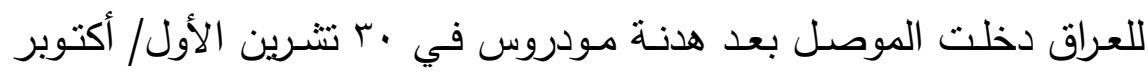

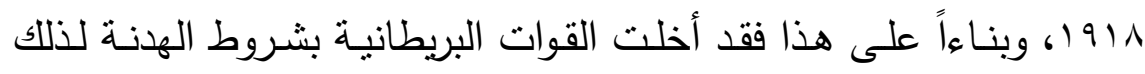
فالاحتلال يعد باطلاً. وقد رفعت الأمر إلى عصبة الأمم التي أرسلت بعثنة

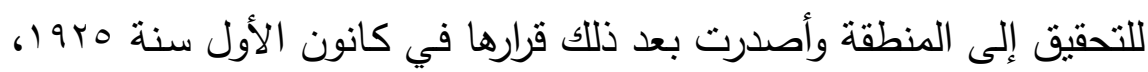
بإبقاء ولاية الموصل ضمن حدود دولة العراق (').

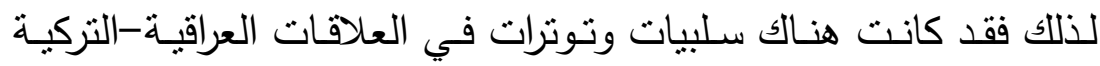
خـلال النصف الأول من عقد العشرينات من القرن العشرين، حتى هدأت

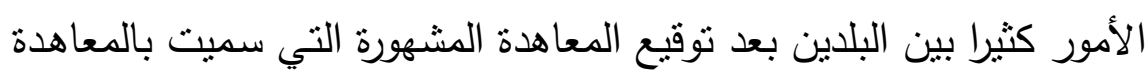

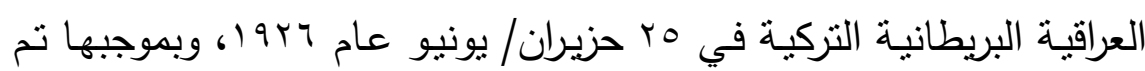
حل مشكلة الموصل، وتم تحديد الحدود البرية العراقيـة مـع تركيا، كما ظل فئل قائما إلى يومنا هذا. بعد عـام 1947 حدث تقارب بين العـراق كدولـة- ولـو تحـت الوصـاية

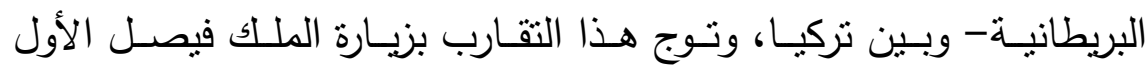

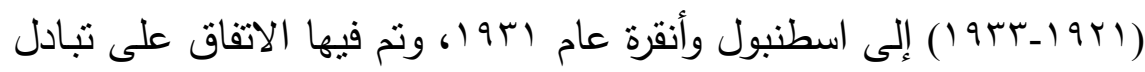

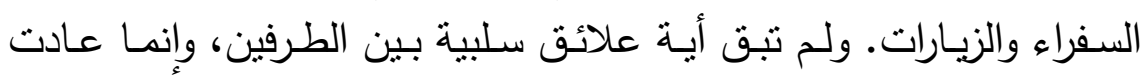

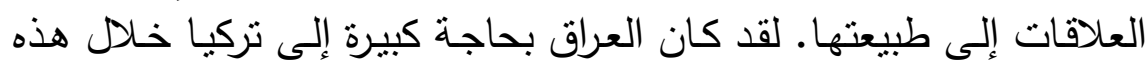


المدة من الناحية الإداريـة والثقافية والاجتماعية. ومنذ استقلال العراق عام

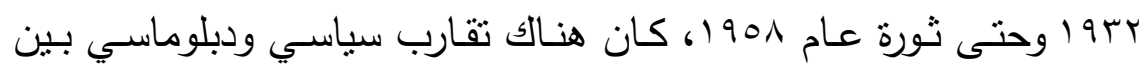

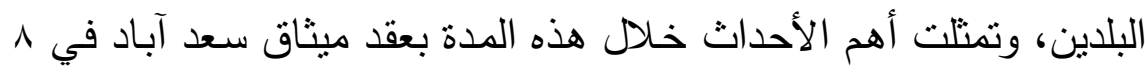

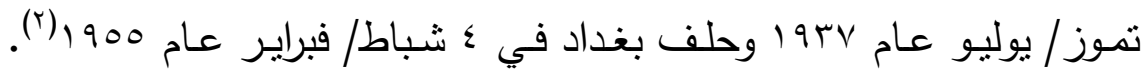
ويمكن القول بأن العلاقات خلال هذه المدة تميزت بالتقارب والتعاون بين

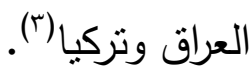

خلال عقدي الستينات والسبعينات أظهرت استراتيجية السياسة الخارجية

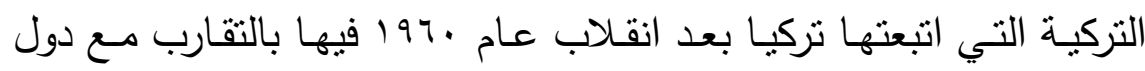

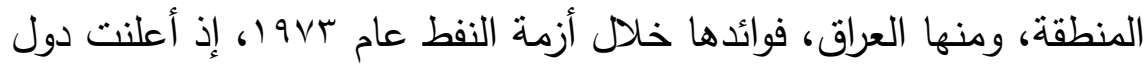
أوبك، التي يعد العراق أحد أعضائها المؤسسين، أن تزويد تركيا بالنفط لن أنهاف يكون محدوداً. ونتيجة لذلك، بدأ تتفيذ خط أنابيب النفط بين العراق وتركيا،

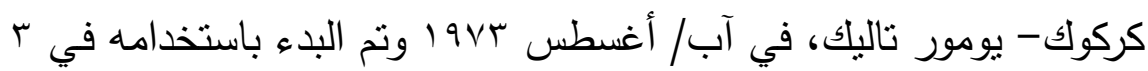

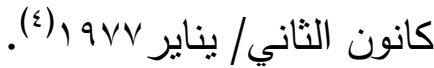
ولكن مسن جهةٍ أخرى أصبحت مشكلة حقوق المياه مثنار خـلاف بين

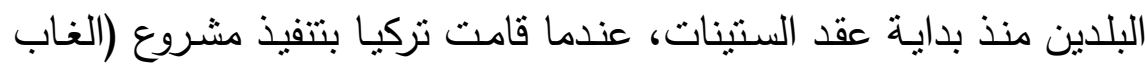

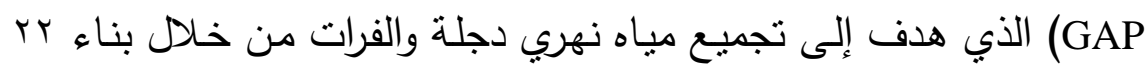

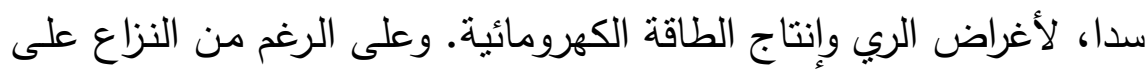

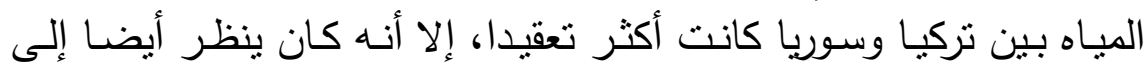
مشروع الغاب من قبل العراق بمثابة تهديد له. وزادت حدة التوتز بين التين تركيا والعراق حول هذه المشكلة خلال عقدي الثمانينات والتسعينات(ث).

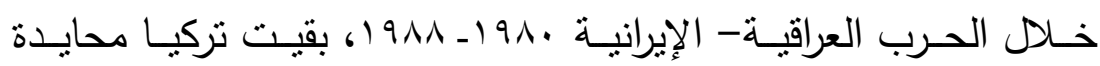

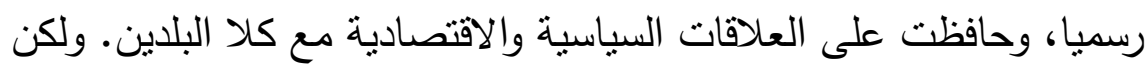

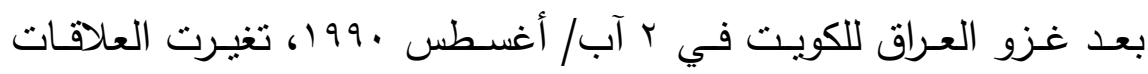
العراقية التركية بشكل كبير ودخلت مرحلة القطيعة تقريبا، خاصـة بعد قيام تركيا بتطبيق الحظر على العراق في إطسار فراري مجلس الأمسن الدولي 
الأول ذي الـرقم 70 بتـاريخ مب آب/ أغسطس •9919، والثـاني ذي الـرقم

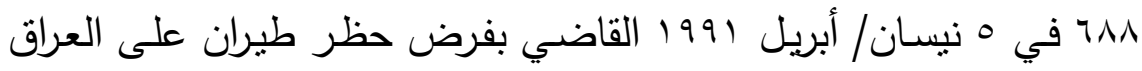

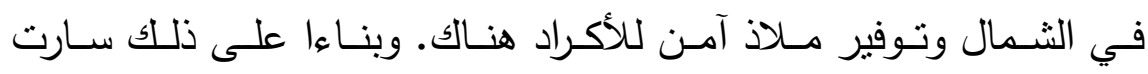

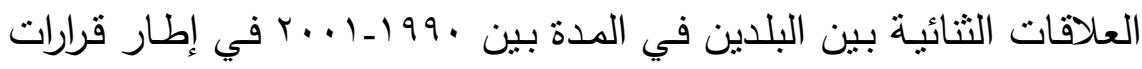

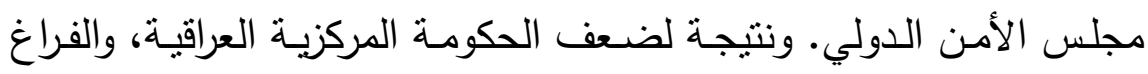

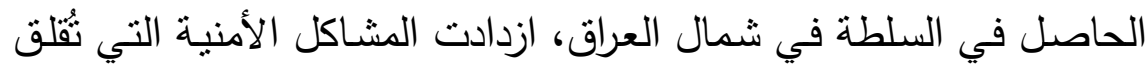

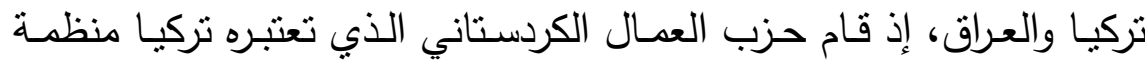
(إرهابية) بتكثيف هجماته ضد نركيا عبر شمال العراق(؟). أولاً: تركيا والعراق بعد الاحتلال الأمريكي سنة ب... r بات

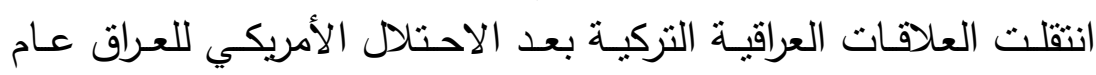

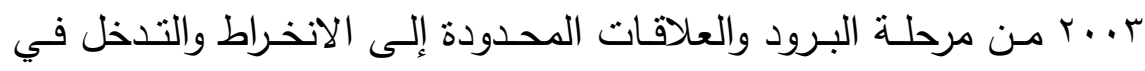

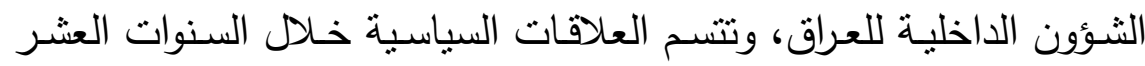
الماضية بالخلافات والتوتر تارة بسبب عدم الاستقرار السياسي والأمني في

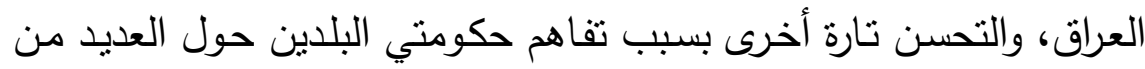

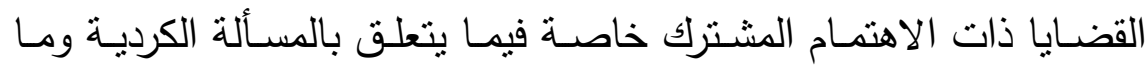
يوصف بـ (الإرهاب) والأمن الإقليمي والنفط.

أ. تركيا ومشروع قوات حفظ السلام الدولية في العرلق عقب الاحتالل الأمريكي للعراق بأثهر طرح الجانب الأمريكي مشروعاً

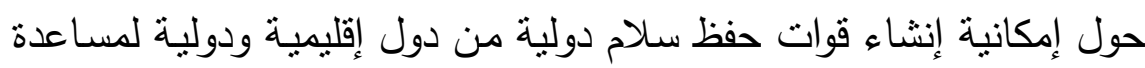

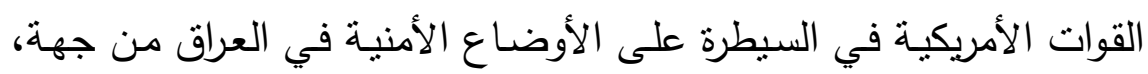

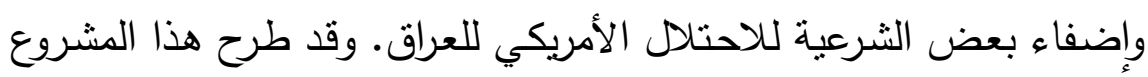
من الجانب الأمريكي خلال زيارة وزير الخارجية التركي الأسبق (عبداله غُل 


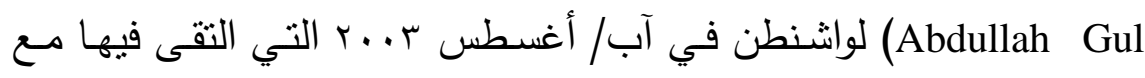
نظيره الأمريكي (كولن باول Colin Paul) ومسؤولين آخرين في وزارة الدفاع

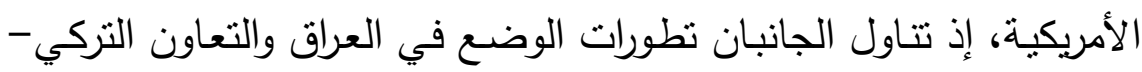

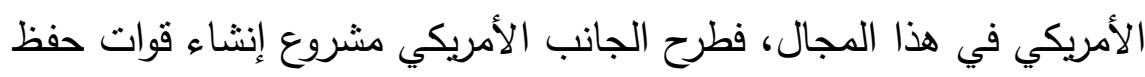
سلام دولية في العراق على الجانب التركي، تكون نركيا جزءاً أساسيا فيه.

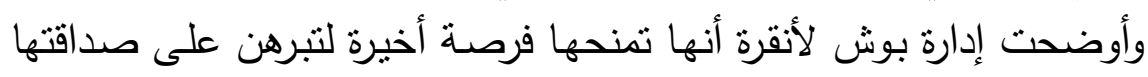
باشتراكها في قوات حفظ سلام دولية في العراق. وقد تحمس القادة الأترالك،

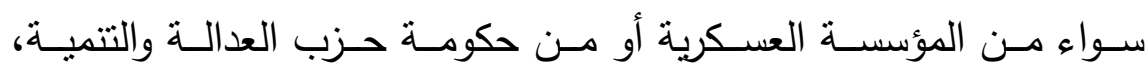

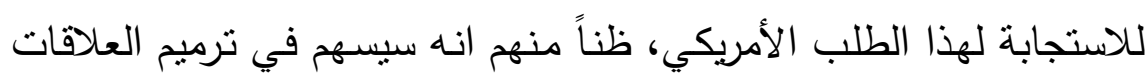
بين البلدين، كما انه سيضمن لتركيا حصة كبيرة في إعادة أعمار العراق،

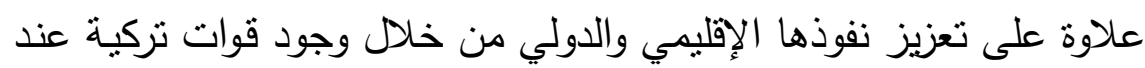

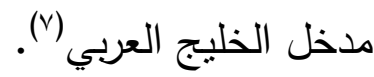
وفي هذا السياق طلبت الولايات المتحدة من نركيا الاشتراك بقوة قوامها (r ( ألف جندي تركي للسيطرة على المنطقة الوسطى التي أطلق عليها بـ "المثلث السني"، وتحديداً المنطقة التي تمر عبر مواقع حساسة واقعة ما بين أربيل وكركوك وتتمدد نقاط القوات التركية نزولاً حتى شمالي بغداد من دون دون المـرور بالسـليمانية وتتـمل تكربت وتتتهـي بـالقرب مـن الحدود السـورية -

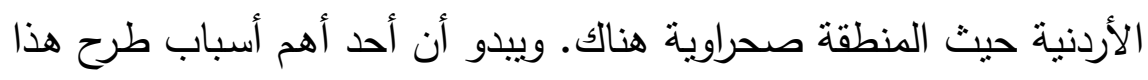

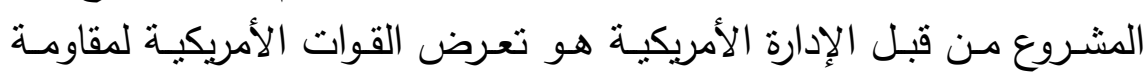

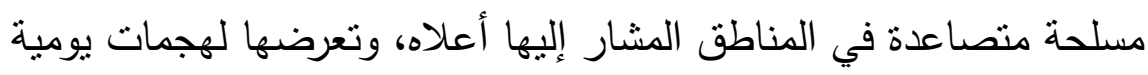

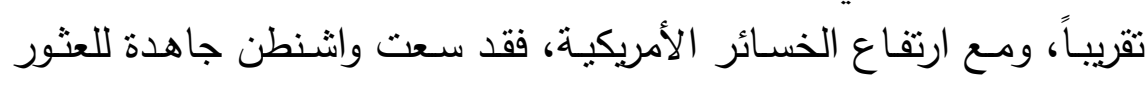

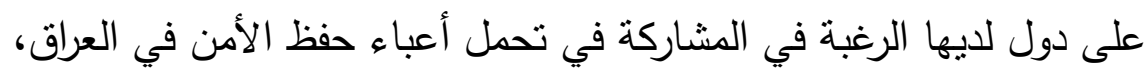

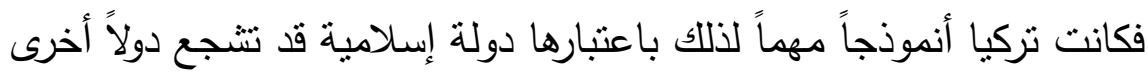
متحفظة منل باكستان وبنغلاديش وغيرهما، على المشاركة في هذه القوات. ومن أهم شروط المشروع هو تمركز القوات التركية في المناطق الكردية ولا 
حيث تتواجد أي من القوات البريطانية أو البولندية أو الاسبانية، لئلا يثير

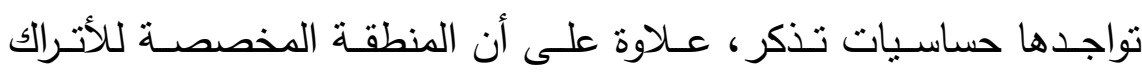

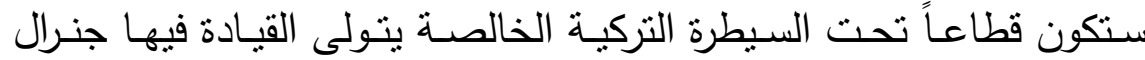
تركي، ومازال الأتراك يفخرون بخبرتهم في مجال حفظ السلام في أفغانستان

$$
\text { والصومال وكوسوفو والبوسنة (^). }
$$

وقد أوردت وكالات الأنباء في حينه أن نركيا وضعت شروطاً النداً لمشاركتها

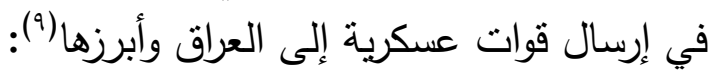
1- إعطاء حقوق للأقلية التركمانية.

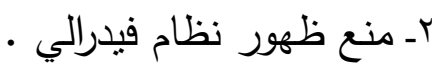
rا بـ نزع سلاح الميلثيات العراقية وقوات البيشمركة الكردية .

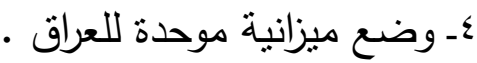
ومع إدراك تركيا أن إرسال القوة المطلوبة سيوفر لهاف فرصة طيبة، إلا انه

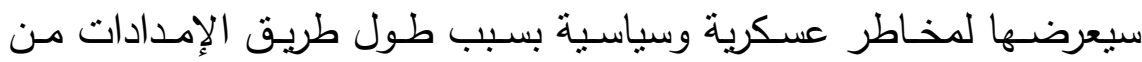

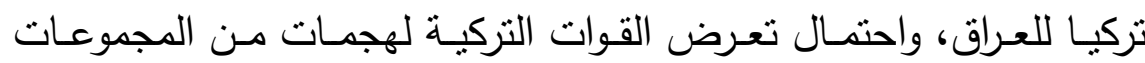

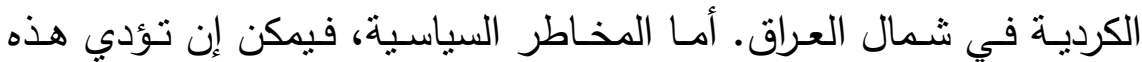

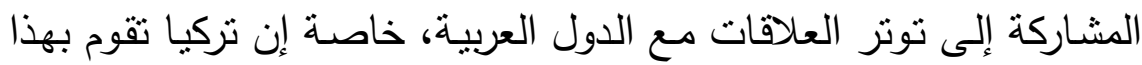
العمل دون غطاء دولي مما قد ينظر إليه على انه مشاركة في الاحتلال

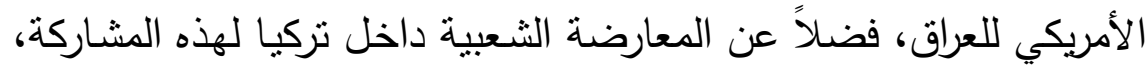

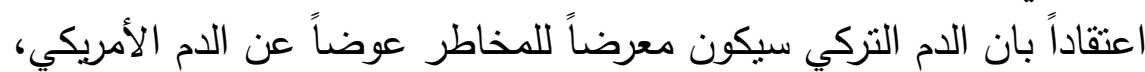

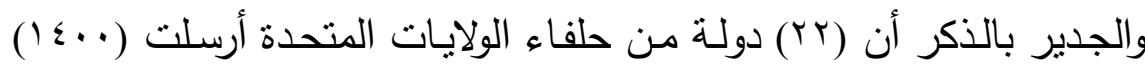

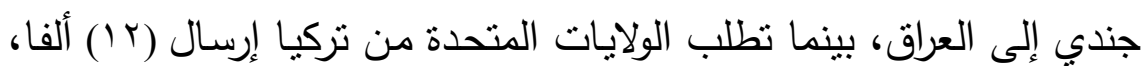

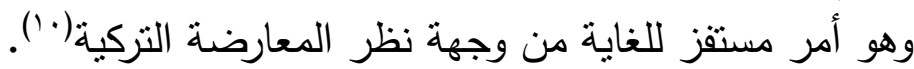

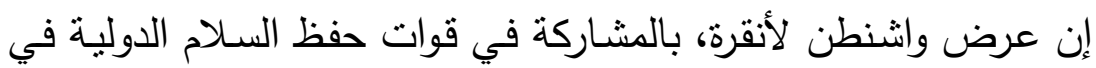

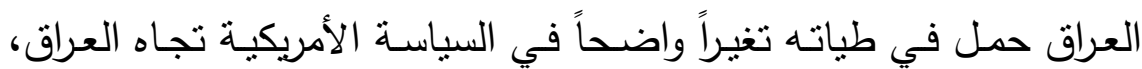

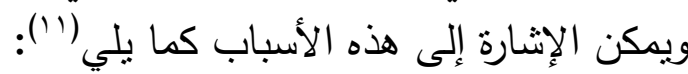


ا • إن مقاومة ما تصفه الولايات المتحدة بـ (الإرهاب) غير ممكنة عبر عزل تركيا التي تقع في قلب هذه الجغرافيا.

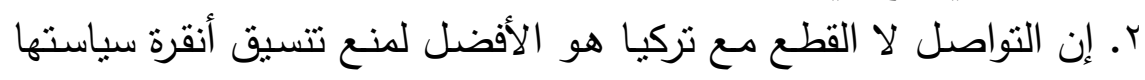
مع دمشق وطهران. ז. إن المصالح الإستراتيجية للولايات المتحدة لا تتحمل ضعفاً أو انقطاعاً

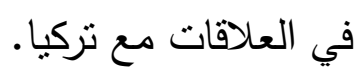
ع. عدم انتظام الوضع في العراق كما تريد الولايات المتحدة.

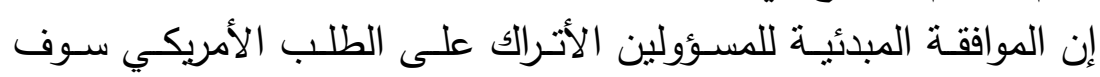

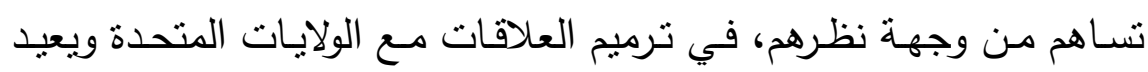

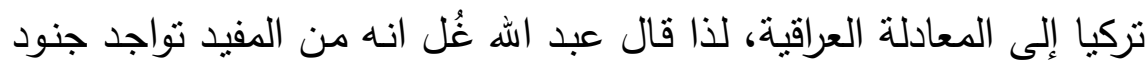

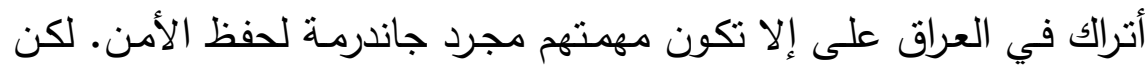

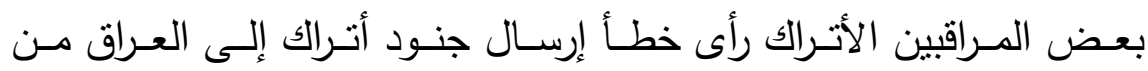

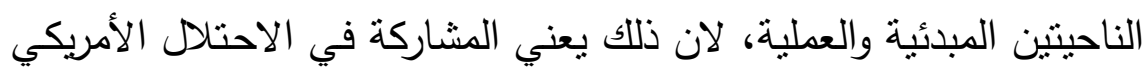

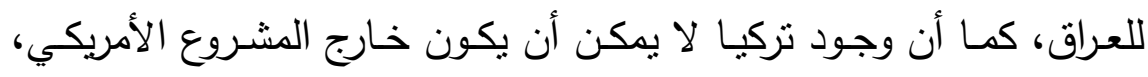

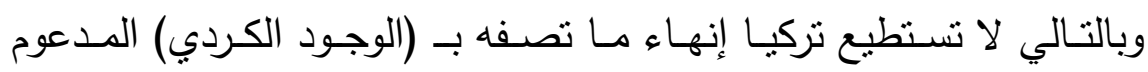

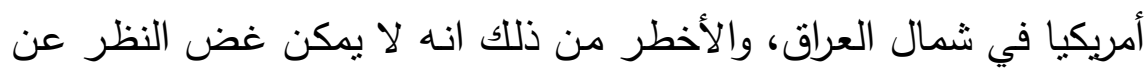

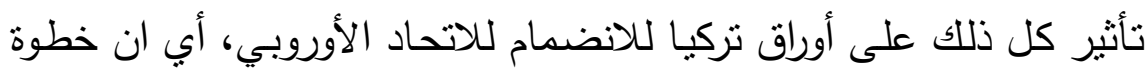

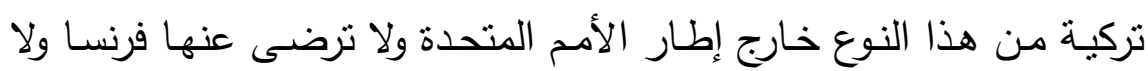

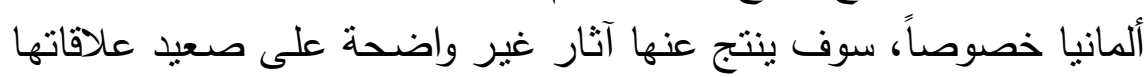
الدولية والإقليمية على حد سواء (rاء).

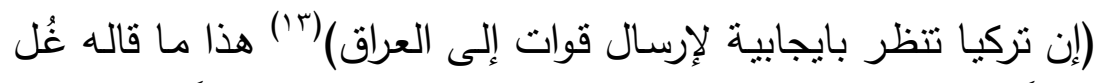

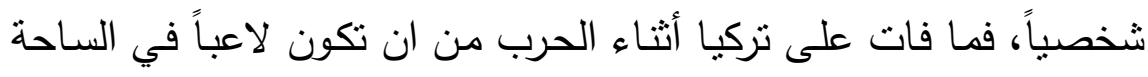

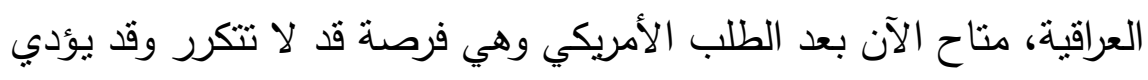

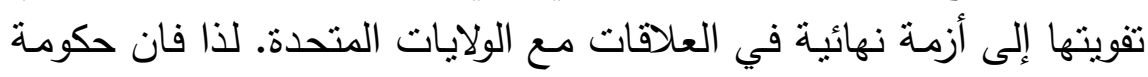

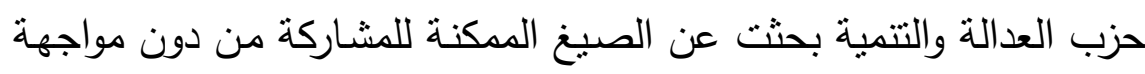


صـعوبات مفاجئة في البرلمـان ومعارضــة مـن جانـب رئسيس الجمهوريـة وآخرين، وهذه المشاركة تبحث عن صبغة شرعية من الزاوية الدولية، وهذه تتطلب إما قراراً من الأمم المتحدة وهذا مستبعد في وقت قريب، وفئ وإما قراراً أطلسيا وهذا غير وارد في المدى المنظور ، وقد اقترح عبداله غُل ان تكون النه

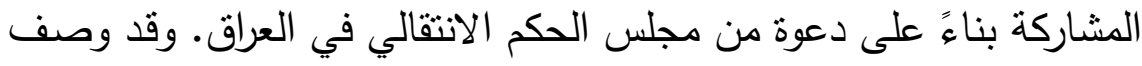

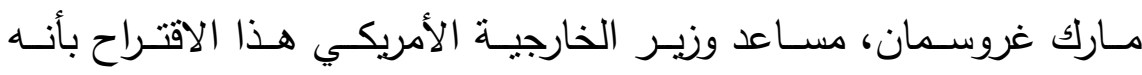

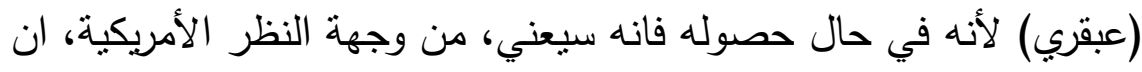
القادة الكرد الممثلين في المجلس الانتقالي مشاركون في توجيه الدعوة، وفي

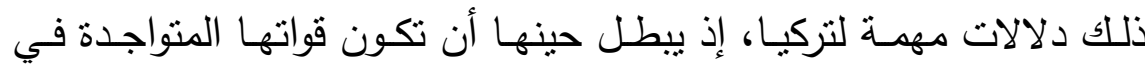

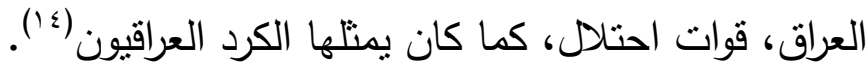

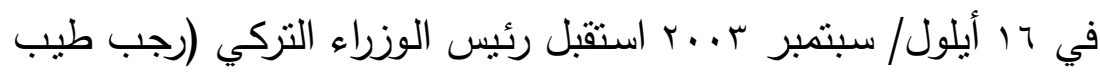
أردوغان Recrp Teyyip Erdogan) السفير الأمريكي في أنقرة (اريك الك

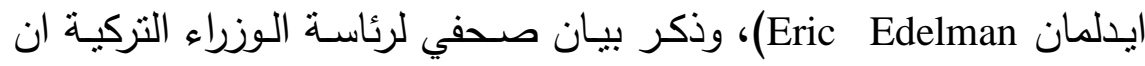

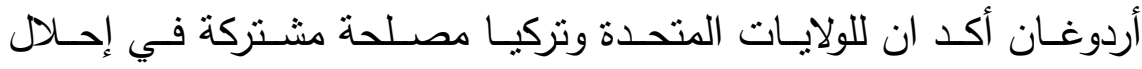
الاستقرار بالعراق، وان تركيا لا تزال تجري تقويماً دقيقاً لمسالة إرسال قواتها

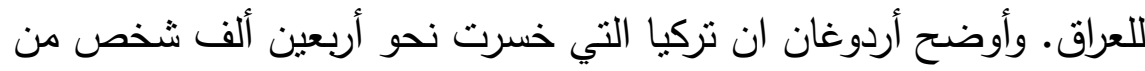

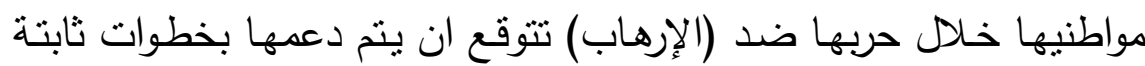

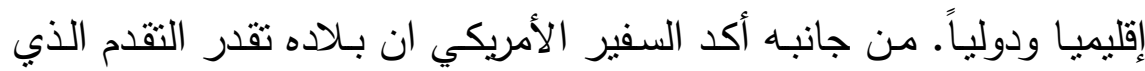
أحرزته تركيا في المجال الاقتصادي وسوف تستمر في تقديم الدعم الـازم لتركيا من خلال زيادة الاستثمارات الأمريكية، وقال ايدلمان: (ان الولائيات

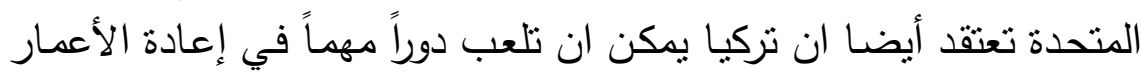
السياسي والاقتصادي للعراق)(10).

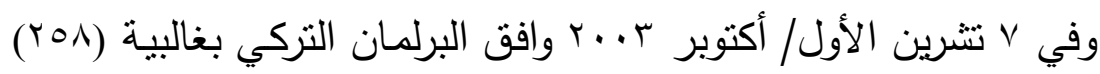

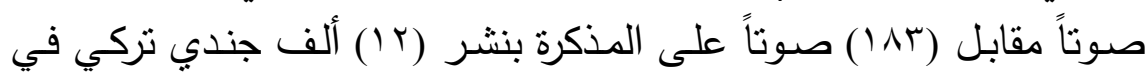


القطاع الأوسط من العراق، واقر إرسال الجنود الأتراك إلى العراق باعتبارها قوات حفظ سلام دولية هناك (17).

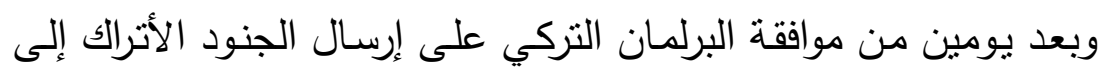

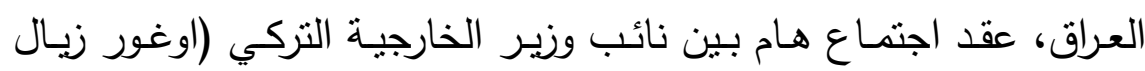
Ugur Ziyal

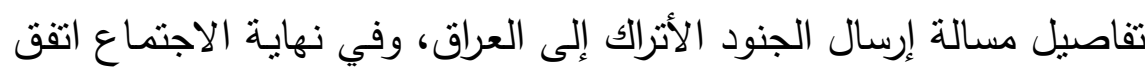

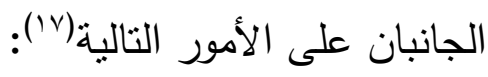

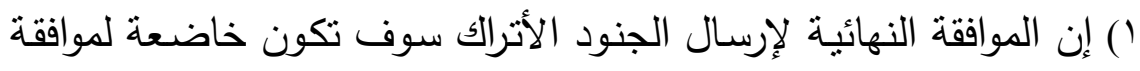
الولايات المتحدة ومجلس الحكم الانتقالي العراقي معاً.

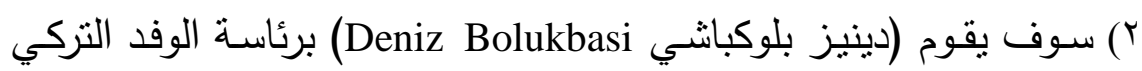
في مناقثناته مع الطرف الأمريكي. r) إن تحديد العدد النهائي للجنود الأترالك سيتوقف على الأنى موقعهم النهائي داخل العراق. ؛) ترغب نركيا بتوضيح آلية الدعم اللوجستي لقواتها، وتريد إرسال خبراء لإعادة أعمار العراق لدعم هدفها في مساعدة العراقيين.

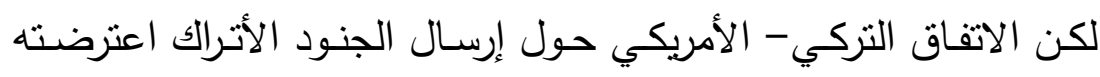

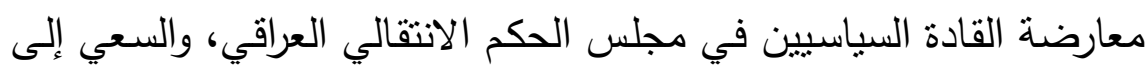

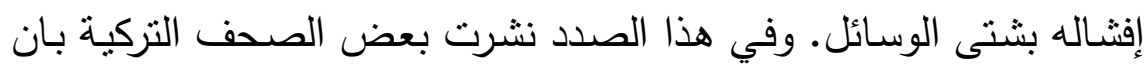

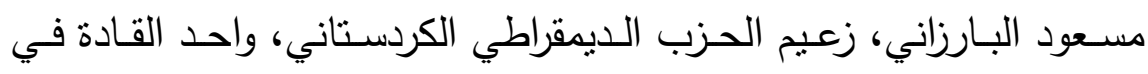

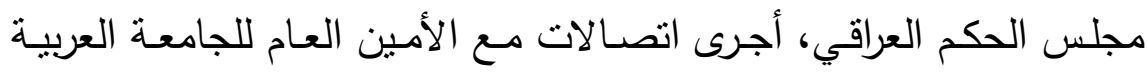
عمر موسى ودعاه إلى معارضة الجامعة لإرسال جنود أتراك إلى الهـ العراق.

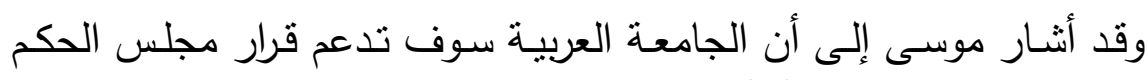

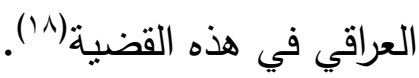

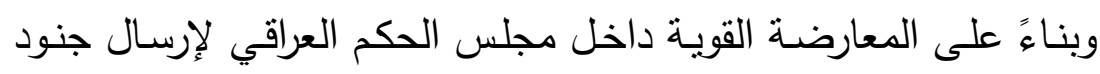

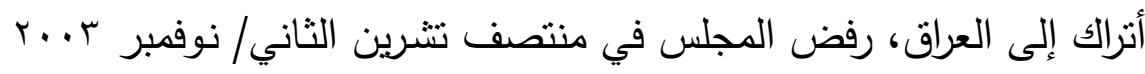


إرسال الجنود الأتراك، نظراً لما يمكن إن يمتلكه ذلك من وجهة نظر المجلس

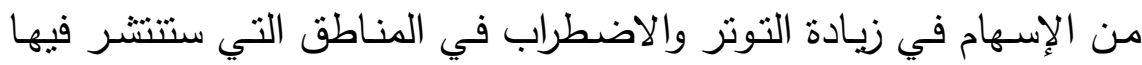

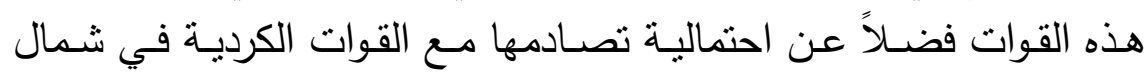

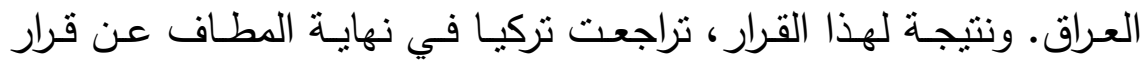
إرسال جنودها إلى العراق (19).

ب. موقف تركيا من تطورات الأوضاع السياسية والأمنية في العراق

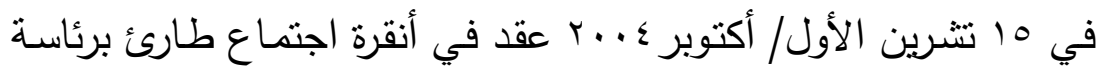

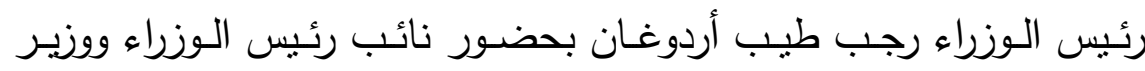

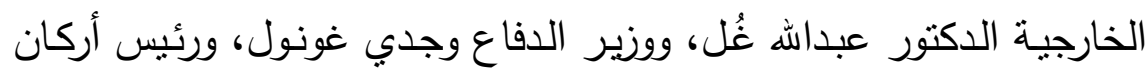

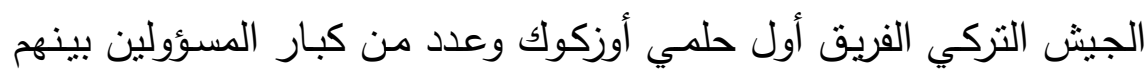

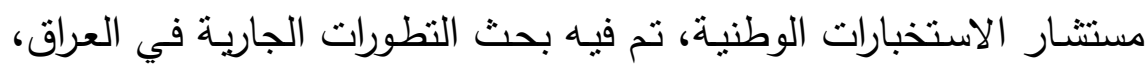

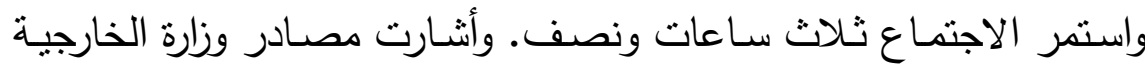

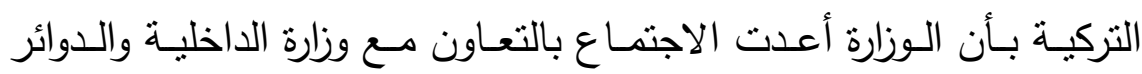

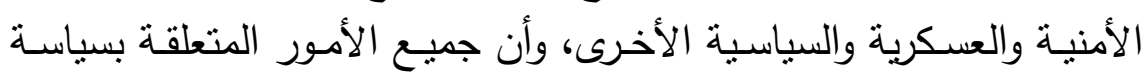

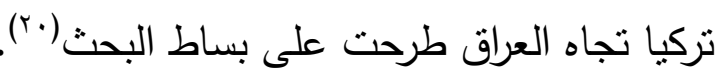

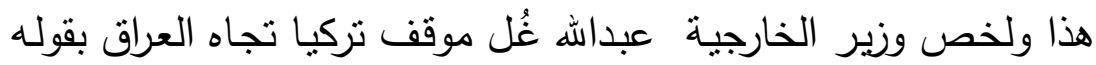

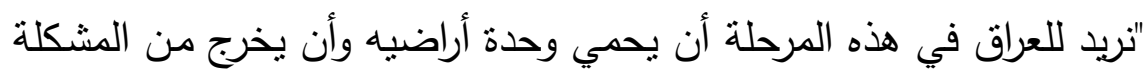

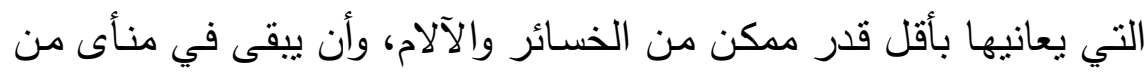

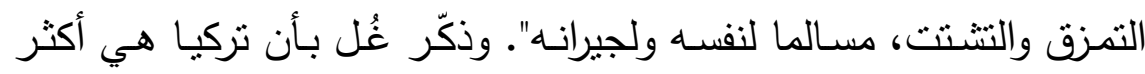

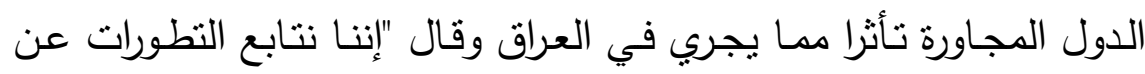

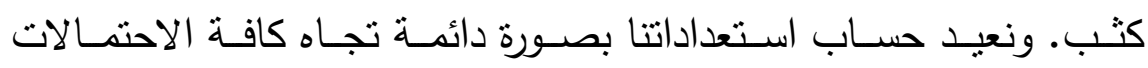

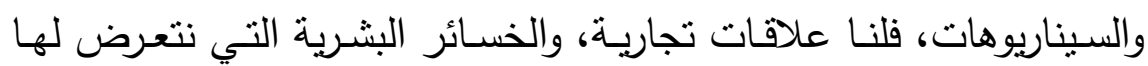

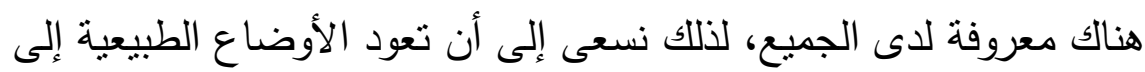

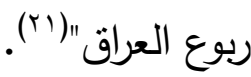


أمـا بالنسبة للمواضيع التي بحثها الاجتمـاع الطـارئ في أنقرة فيمكن

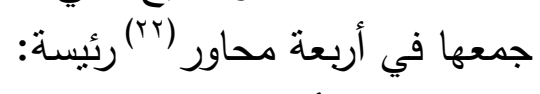

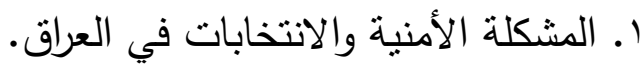

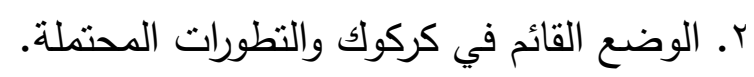

r. r. وجود حزب العمال الكردستاني ونشاطاته في العراق.

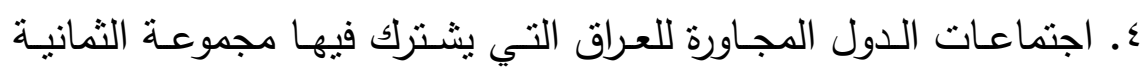

بالإضافة إلى الصين.

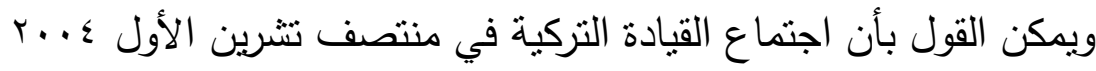

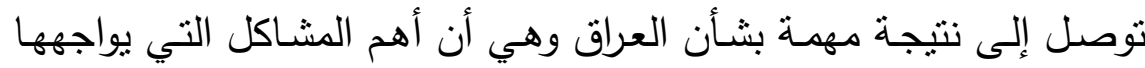

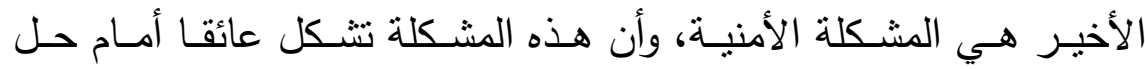

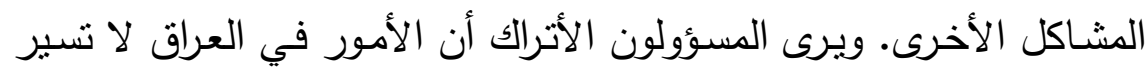

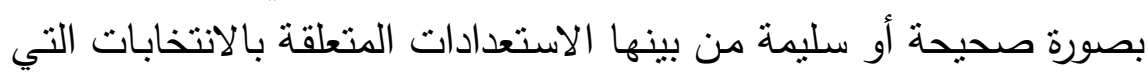

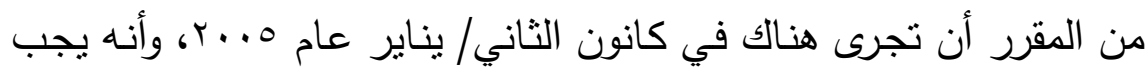

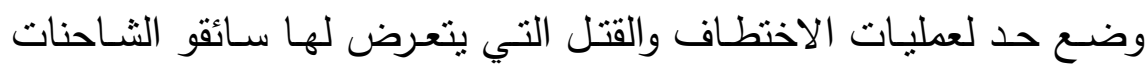

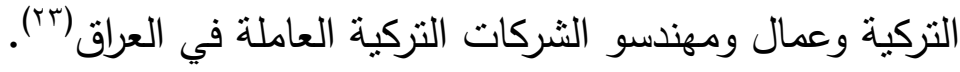

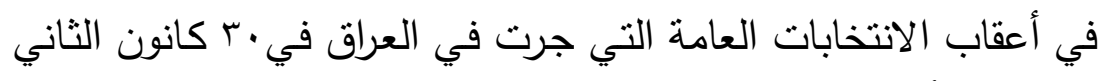

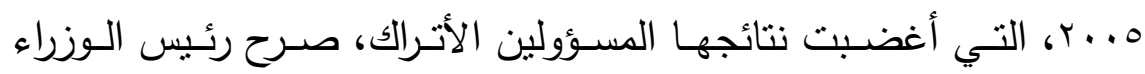

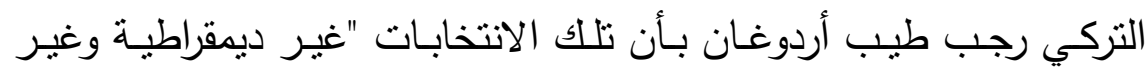

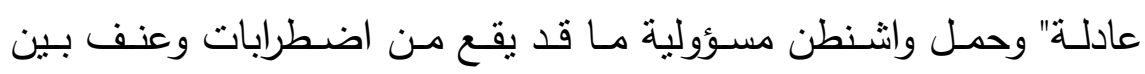

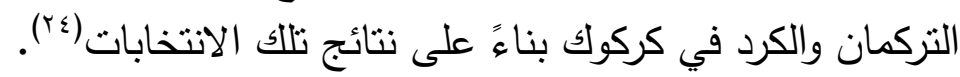

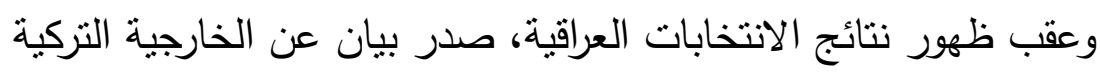

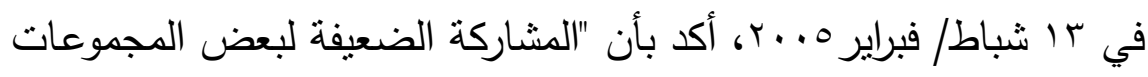

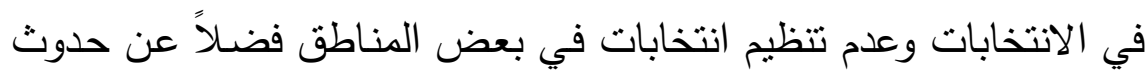

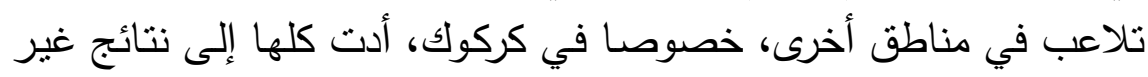

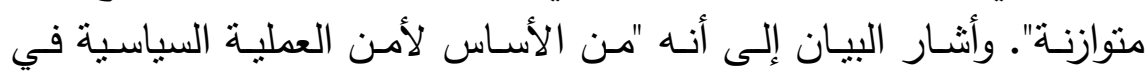


العـراق تصـيح التمثيـل غير العامـل في إدارة البلاد" وقـال البيـان أيضــاً:

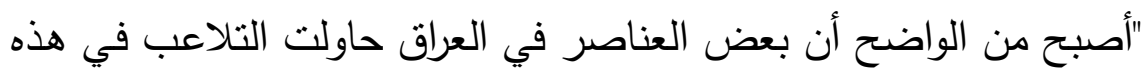
العملية التاريخية وحصلوا على مكاسب إضـافية غير مبررة" في إثـارة إلى لى

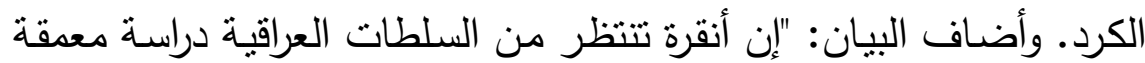

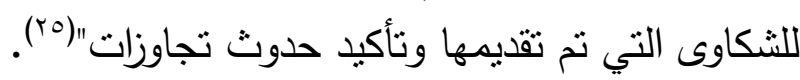

\section{ج. موقف تركيا من مسألة الفيدرالية ومشكلة كركوك} وفيما بتعلق بمسألة الفيدرالية ومشكلة كركوك، أوضحت نركيا موقفها من ذلك، وفي هذا الصدد أثنار عبداله غُل نائب رئيس الوزراء التركي ووزير الخارجية آنذاك في مؤتمر صحفي حين قال معقباً على أخبار تتحدث عن أن أند "جهود الكرد في مجال إقامة دولة فيدرالية في العراق": "لقد وجهنا تحذيراً أثز التطورات الأخيرة في شمالي العراق ومناطق أخرى والتي قد تؤثر على وحدة التهات

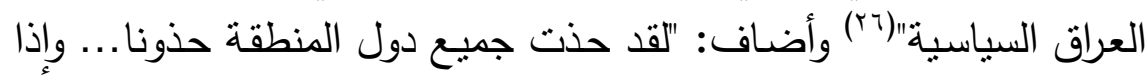
ما استمرت منل هذه التطورات الخطيرة أخثى من أن يتحول العراق مجدداً

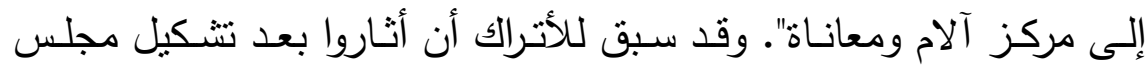
الحكم الانتقالي مسألة حجم مشـاركة التركمان في المجلس وقالة وفالوا ان ذلك غير كاف

وقد عدّ المسؤولون العراقيـون التصـريحات التركيـة تدخلاً في الثـؤون الداخلية للعراق، خاصسة مـا يتعلق بدعوة تركيا الدول المجاورة للعراق لأن

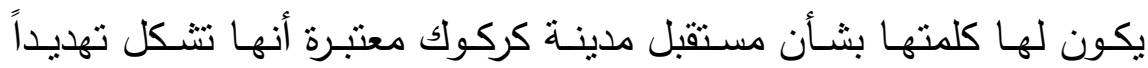
محتملاً لأمن المنطقة. وهددت تركيا بتدويل ما أطلقت عليه (مشكلة مدينة

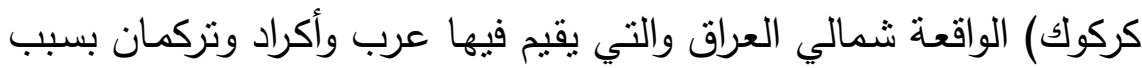

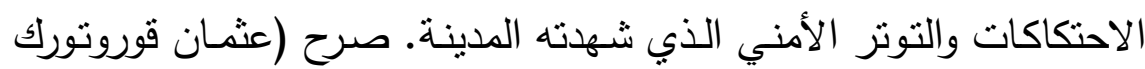

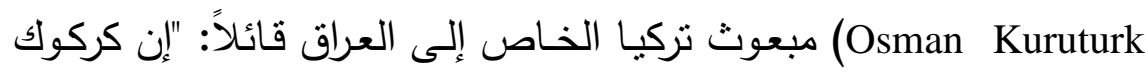

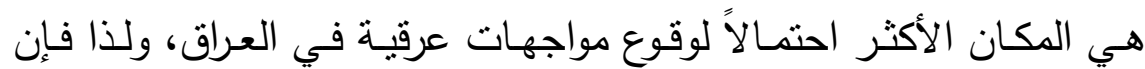


كركوك ليست شأناً داخلياً عراقياً" مشيراً إلى احتمالية حصول "آثار جدية

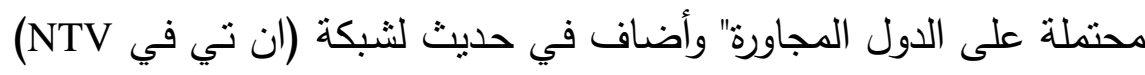

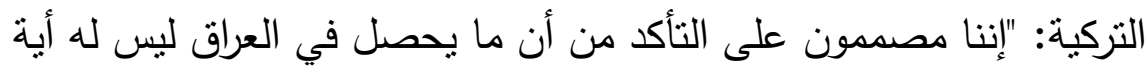

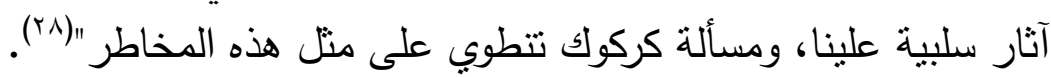

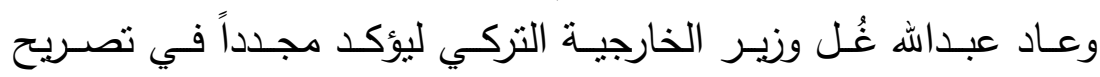

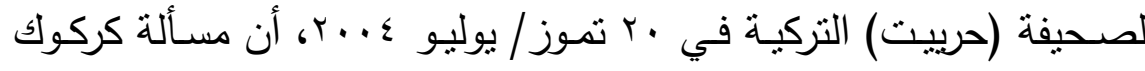

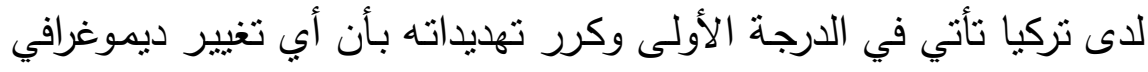

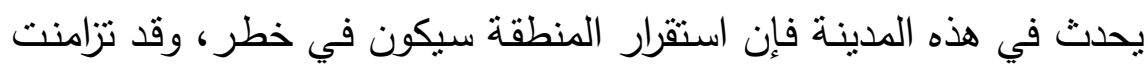

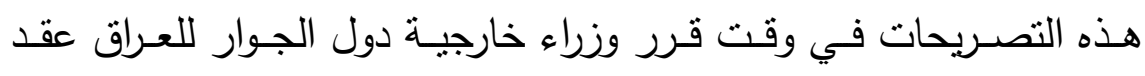

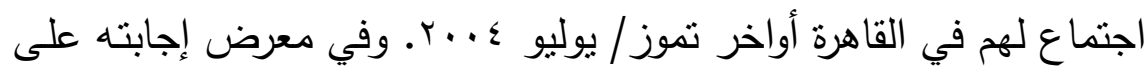

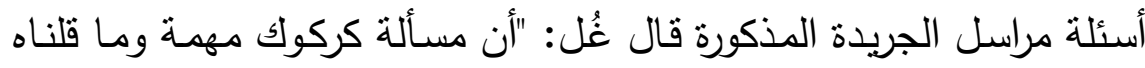

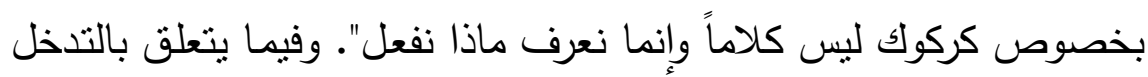

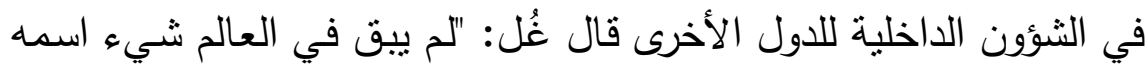

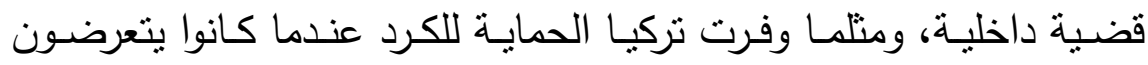

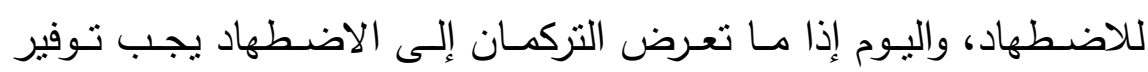

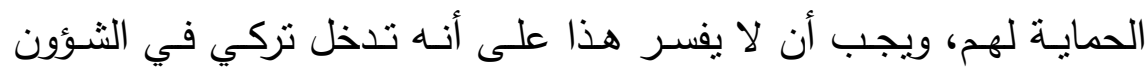

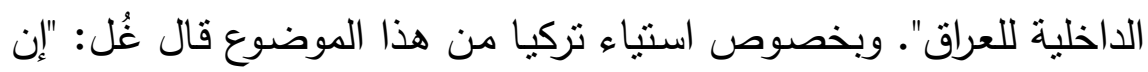

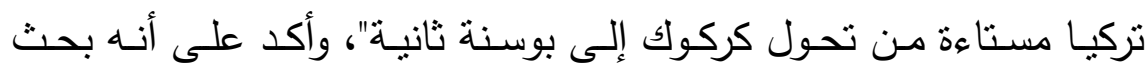

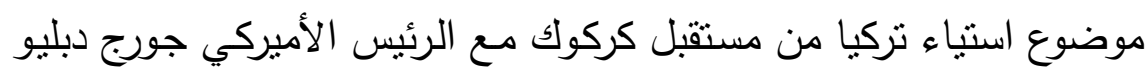

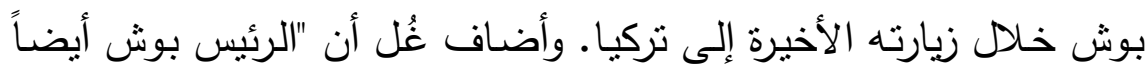
يفكر مثلنا !!"(ra).

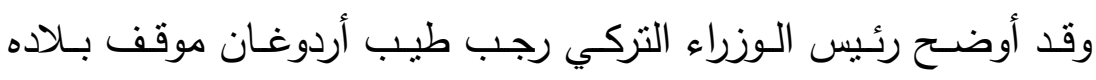

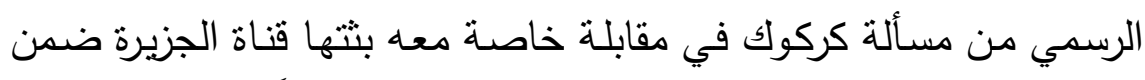

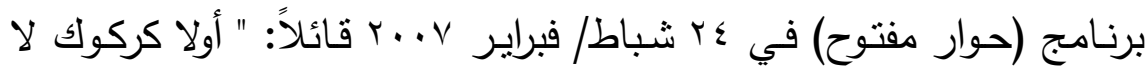

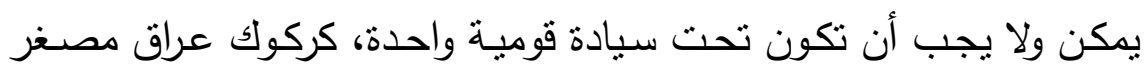


وبالتالي فهي لكل العراقيين، هناك البعض يحاول تغيير التركيبة السكانية

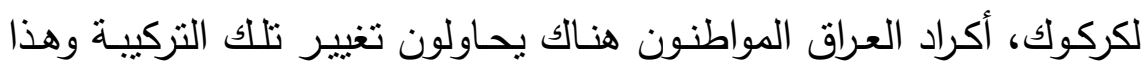

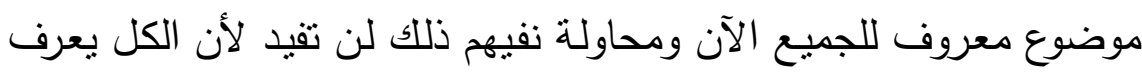

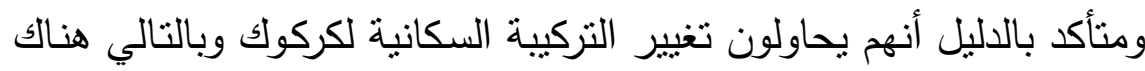

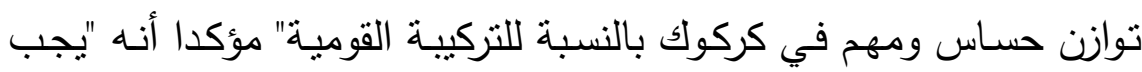

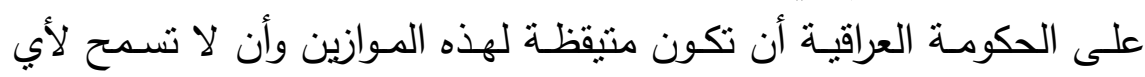

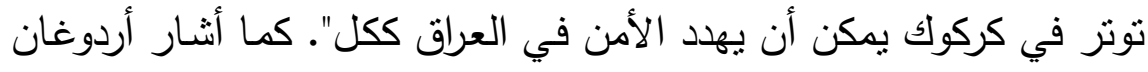

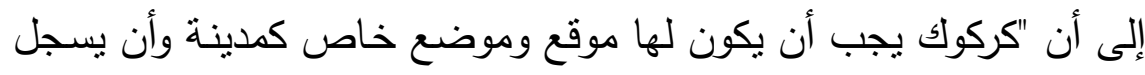

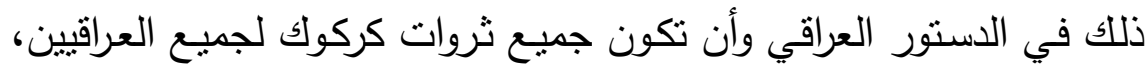

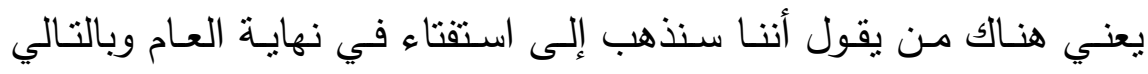

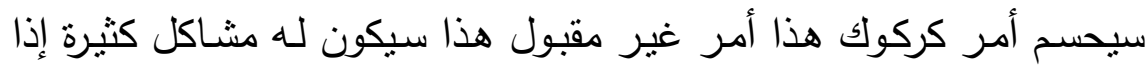

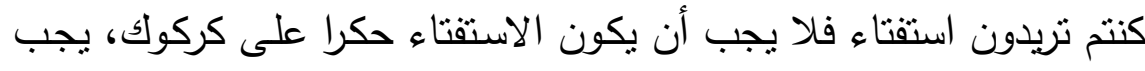

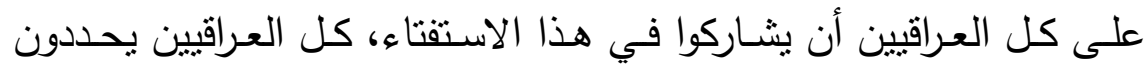

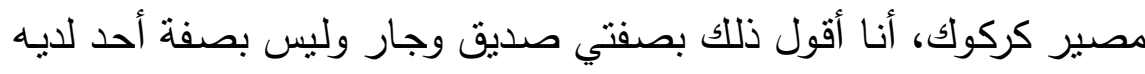

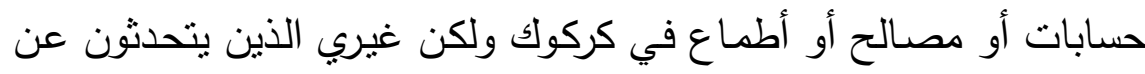

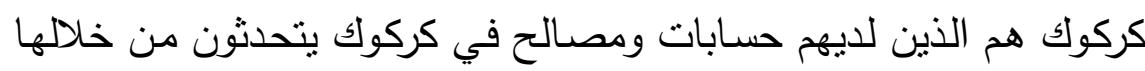

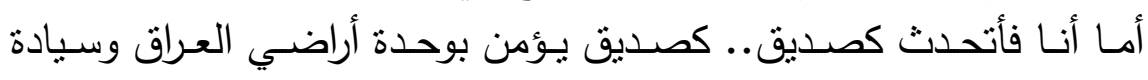

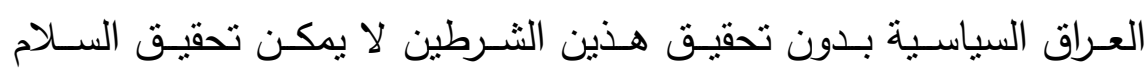

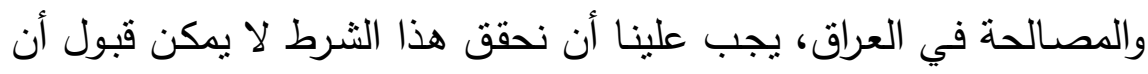

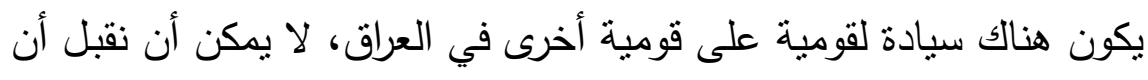

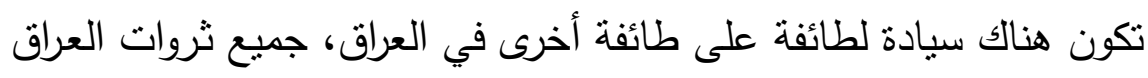

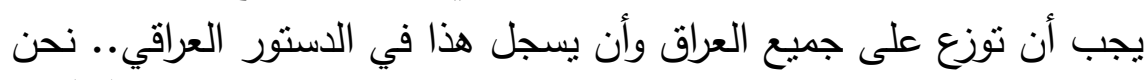

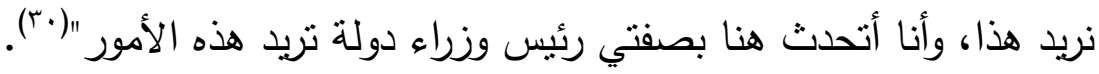

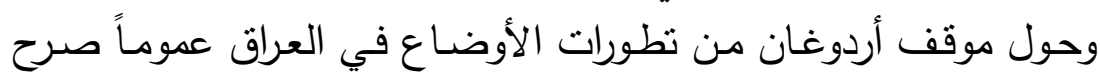

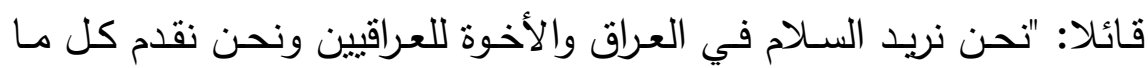


بوسعنا من مساعدات كإرسال الغذاء والدواء والماء والخبز وكل شيء.. كل كل

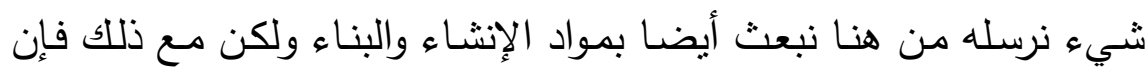

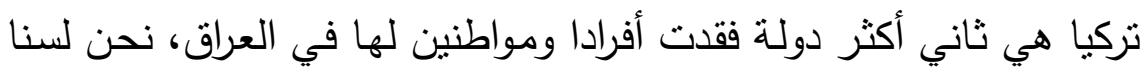

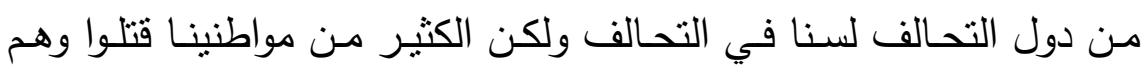
سائقو شاحنات أو عمال أتراك يعملون في العراق أو سائقين ينقلون النفط

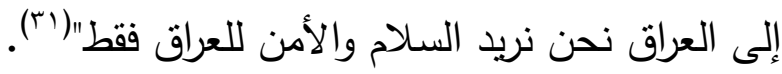

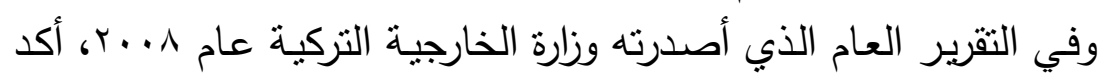

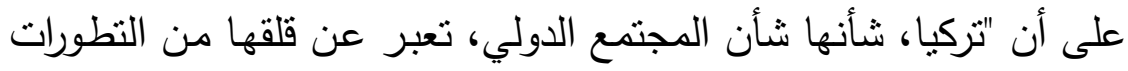

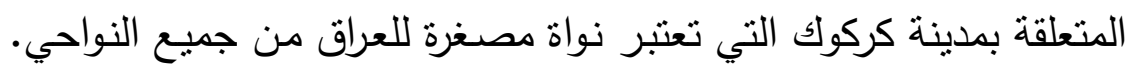

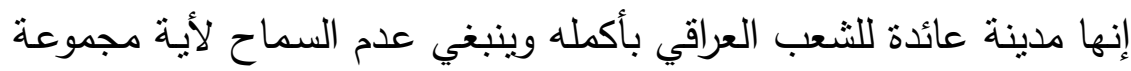

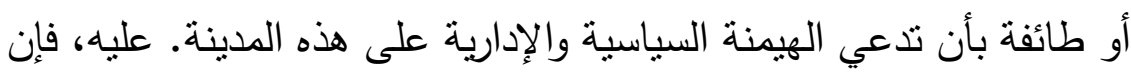

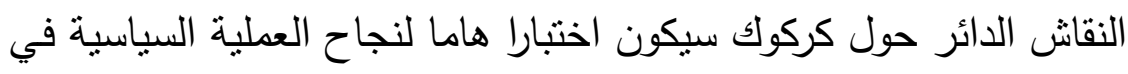

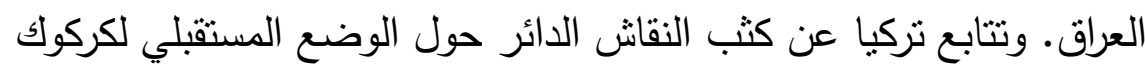

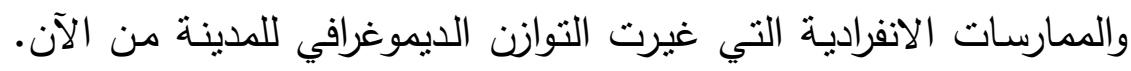

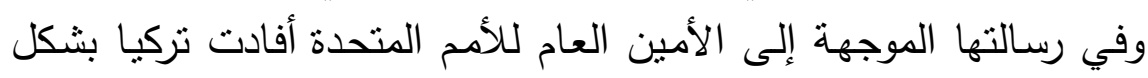

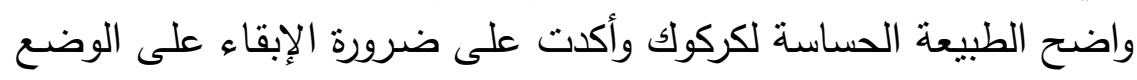

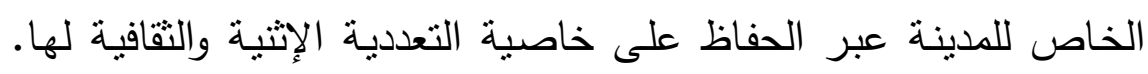

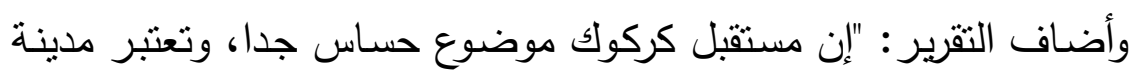

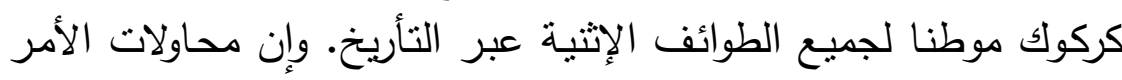

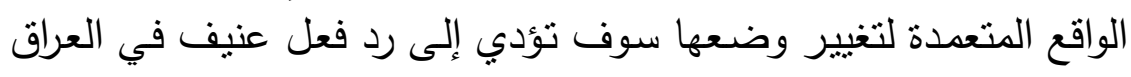

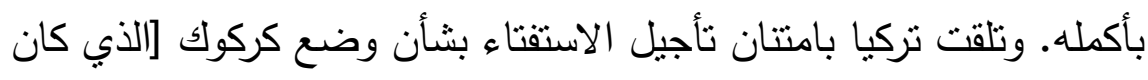

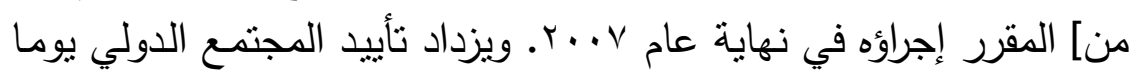

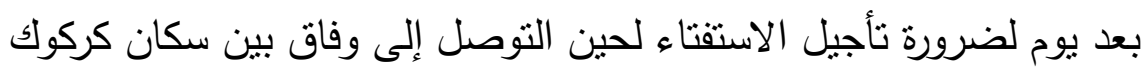
بجميع طوائفه الإثثية، الأمر الذي تدعمه نركيا بقوة"(rr). 
كما جددت الخارجية التركية موققها من مشكلة كركوك عبر بيان أعلنته

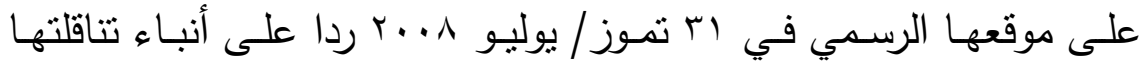
وسائل إعلام مختلفة عن تصريحات بعض المسؤولين الأكراد من أن تركيا

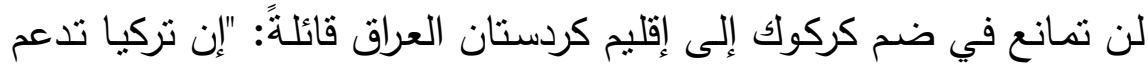
دائما الحل السياسي بالاتفاق الذي يوفر حياة انسجام لجميع الأطراف داخل المجتمع العراقي معا. وتدافع على أن يكون لكركوك منزلة خاصة يتم [فيها]

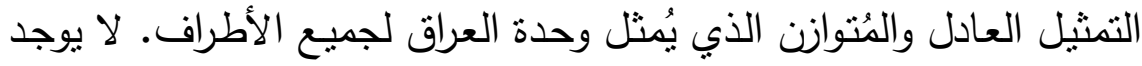

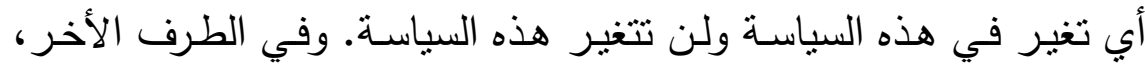

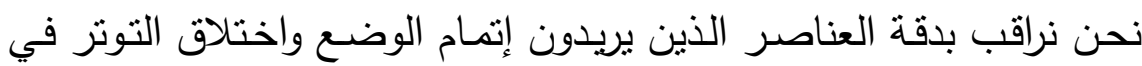
كركوك. إن هذا التوتر لن يعم بالفائدة على أحد، حتى على الذين يفتعلونهـ.

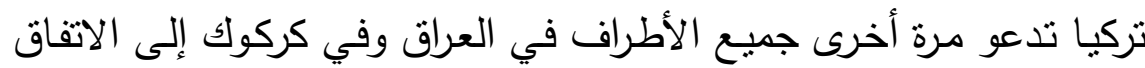

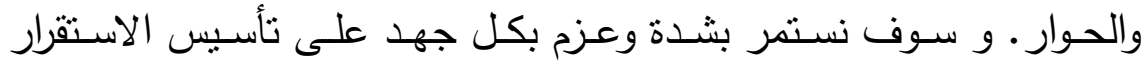

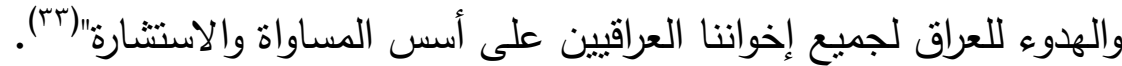

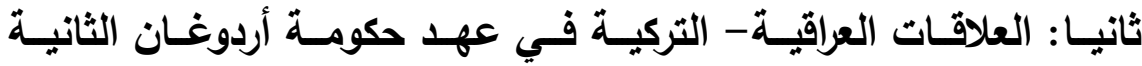

$$
r .11-r . . v
$$

يمكن القول إن العلاقـات العراقيـة - التركيـة وخصوصـاً فـي المجـالين السياسي والاقتصادي قد دخلت مرحلة جديدة من التطور الحقيقي الملموس ونس

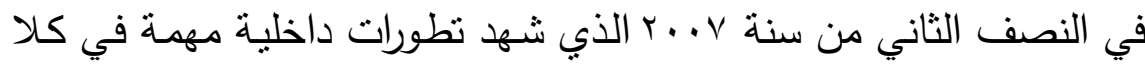

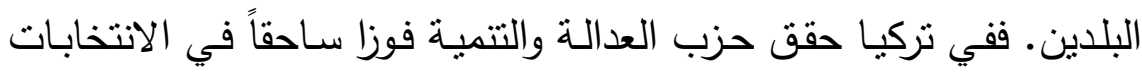

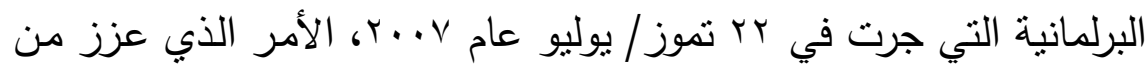
الاستقرار السياسي في تركيا، ودفع الحكومة بثقة أكبر نحو تتفيذ إصلاحاتها

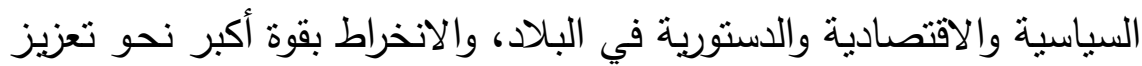

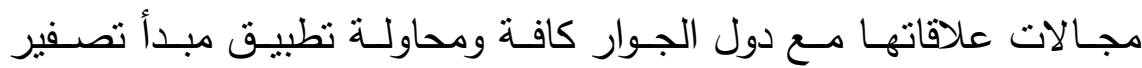

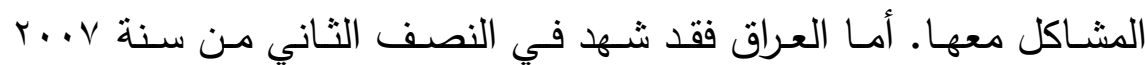


انطلاق حملة أمنية مكثقة للسيطرة على تدهور الأوضاع الأمنية في البلاد،

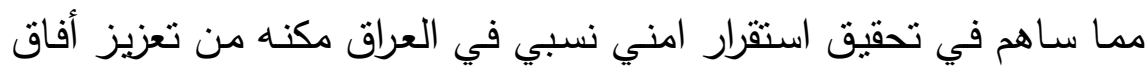

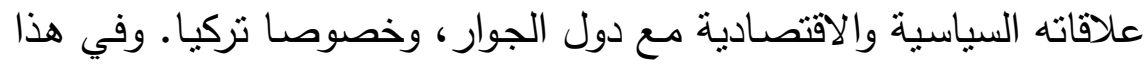

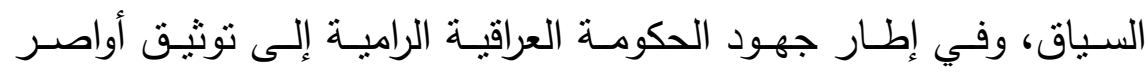

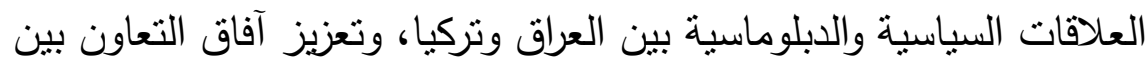

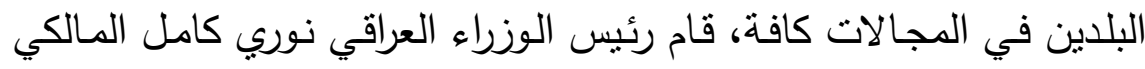

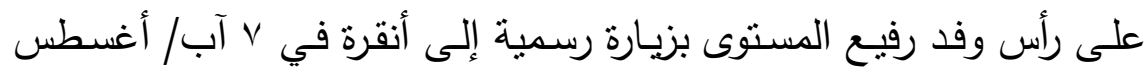

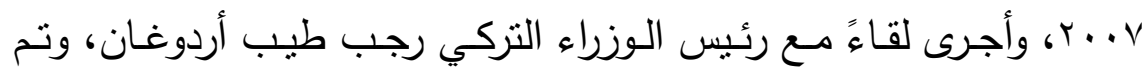

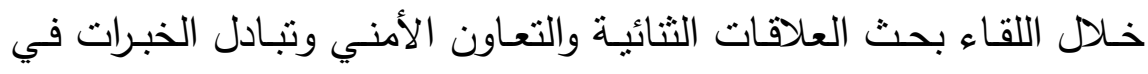

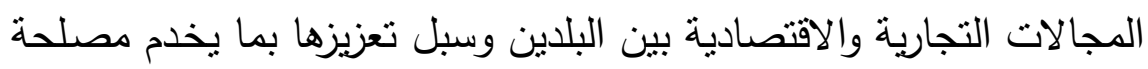

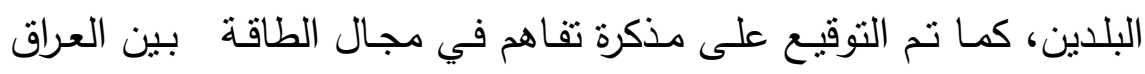

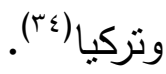

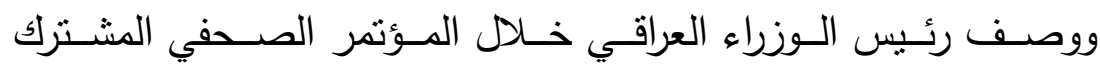

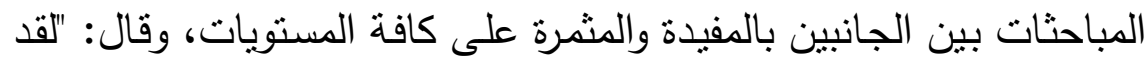

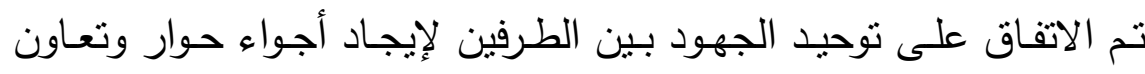

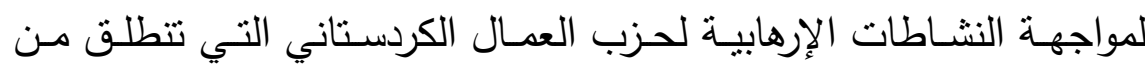

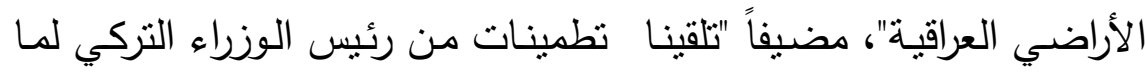

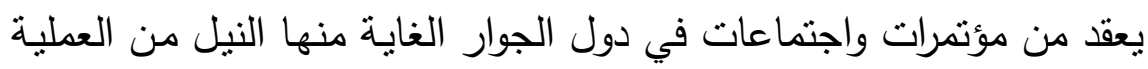

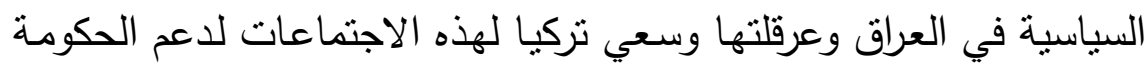

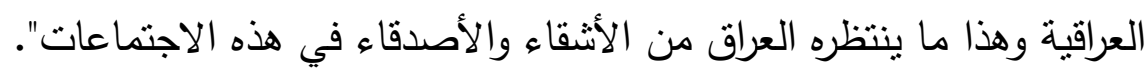

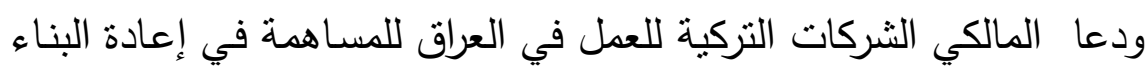

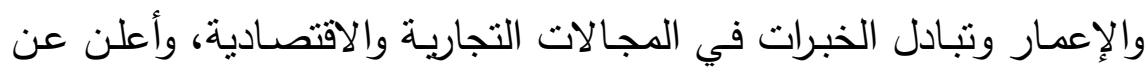

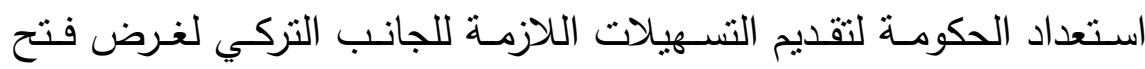

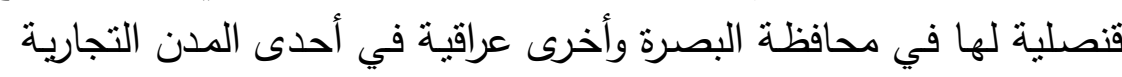

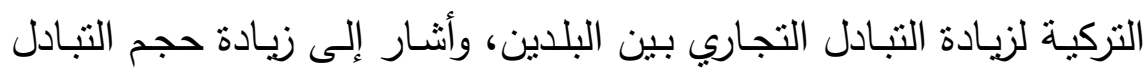




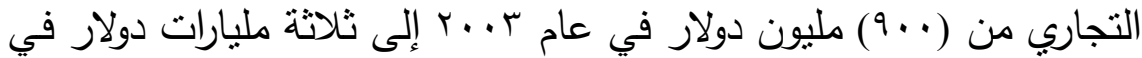

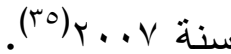

من جانبه جدد رئيس الوزراء التركي رجب طيب أردوغان دعمه الكامل

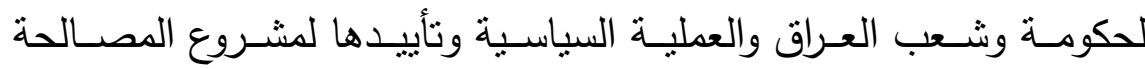

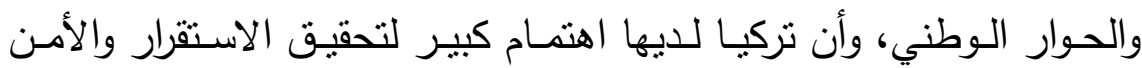

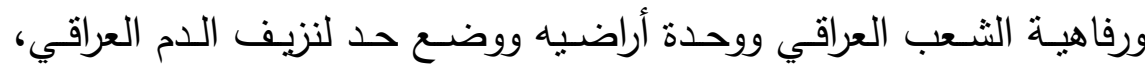

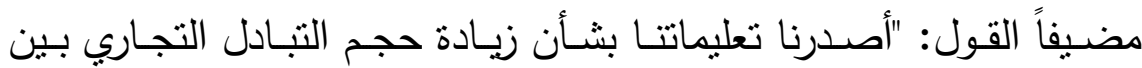

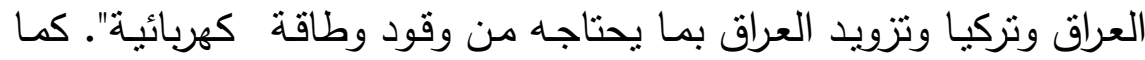

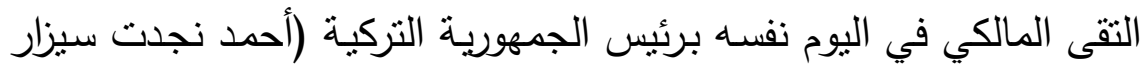

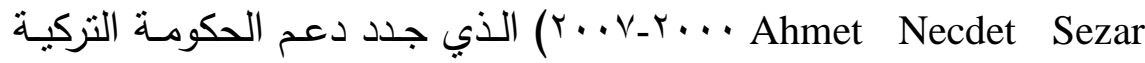

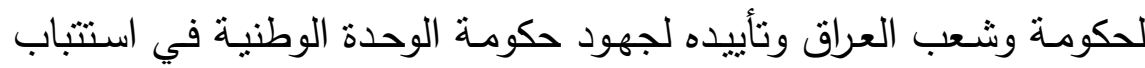

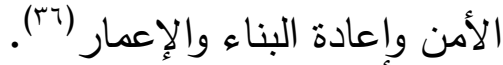

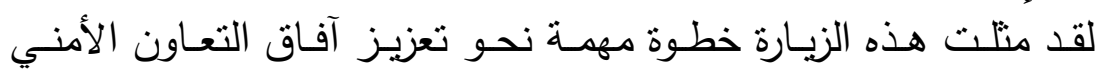
والاقتصادي بين البلدين، فضـلا عن تعزيز وتطوير الأواصر السياسية بين الإنين

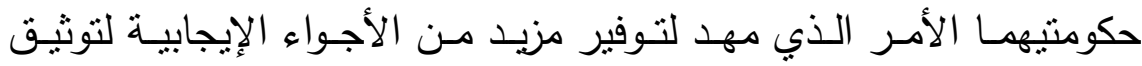

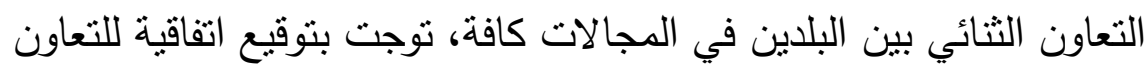

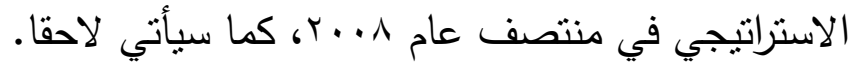

ا. تأسيس المجلس الأعلى للتعاون الاستراتيجي بين العرلق وتركيا عام .r...

لقد أسهمت الزيارات الرسمية المتبادلة بين مسؤولي البلدين في التمهيد

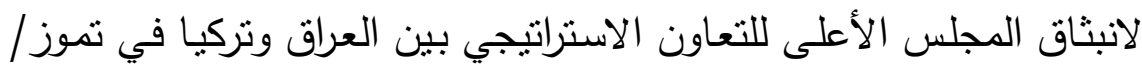

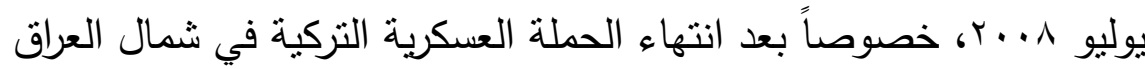
في شباط من العام نفسه. وقد عكست هذه الزيارات رغبة مسؤولي البلدين في تطوير علاقاتهـا الثنائيـة إلى مستويات إستراتيجية على الصـعيدين 
السياسي والاقتصادي، وهو ما انعكس فيما بعد على ارض الواقع في عقد

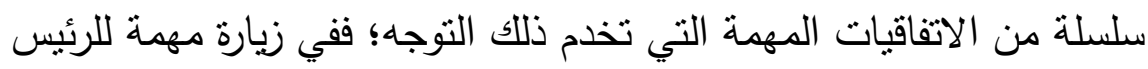

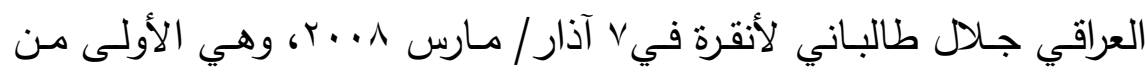

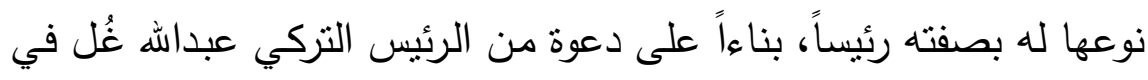

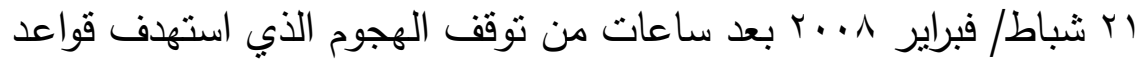
يستخدمها حزب العمال الكردستاني لشن هجمات داخل الأراضي التركية.

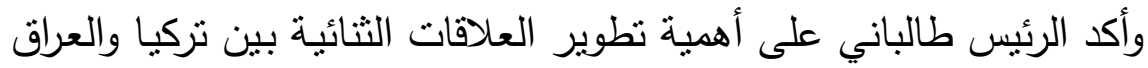
وصرح قائلاً: "إن العراق يأمل في إقامة علاقات إنية إستراتيجية ومنينة مع تركيا

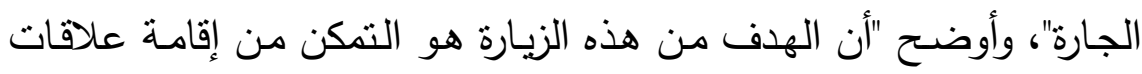

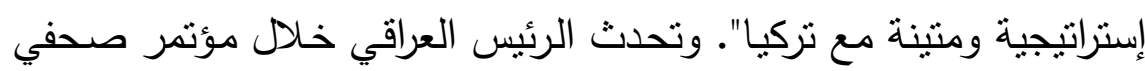

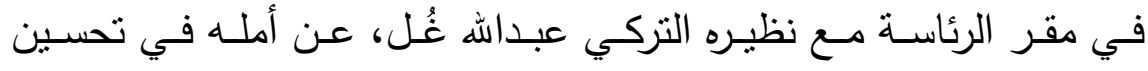

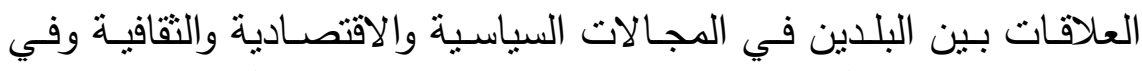

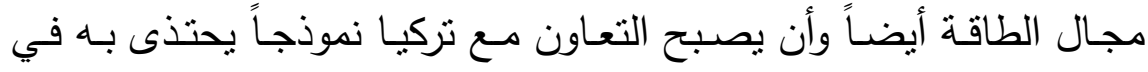

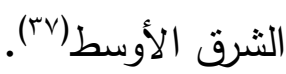

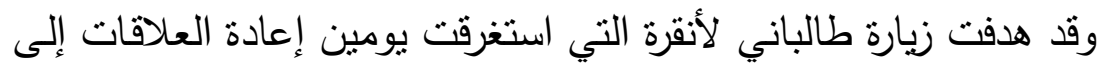

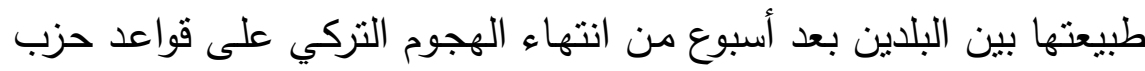

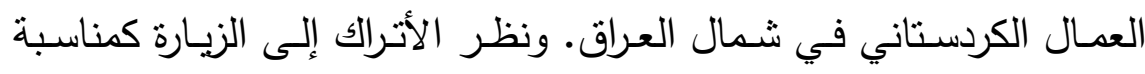

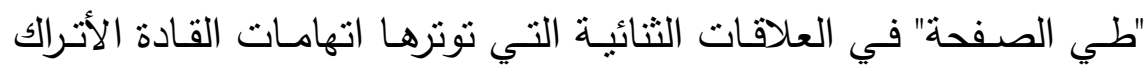
لأكراد العراق بالتساهل حيال المسلحين الأكراد ودعم تحركاتهم في مناطقهم.

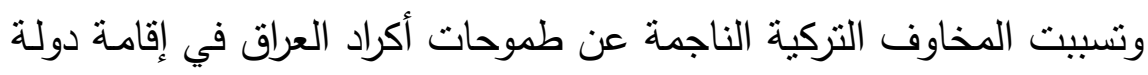

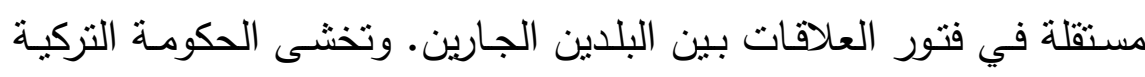

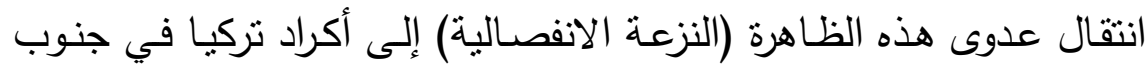

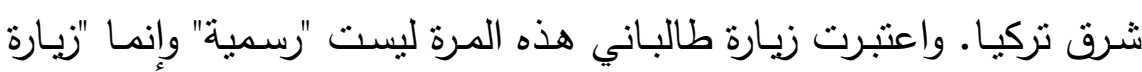

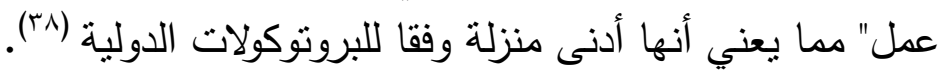


لكن الزيارة الأهم في تاريخ العلاقات بين البلدين، والأولى لرئيس وزراء

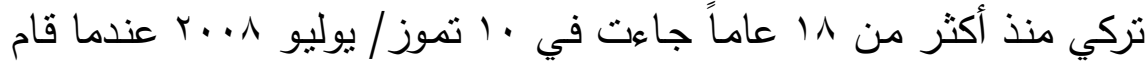

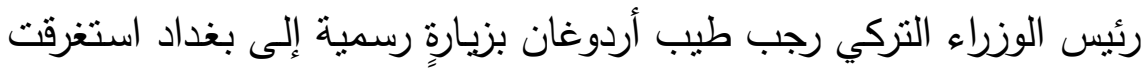
يوماً واحداً، ووقع مع نظيره العراقي نوري المالكي اتفاقية سميت بـ (الإعلان

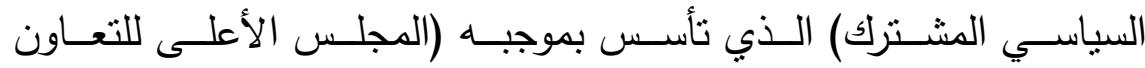

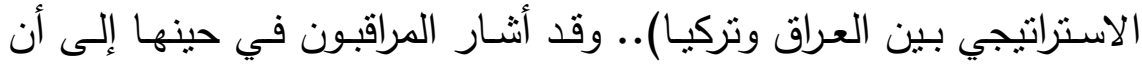
التوقيع على ذلك الإعـلان يعد تدشينا لعهد جديد من العلاقات العراقيـة-

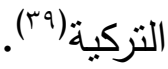

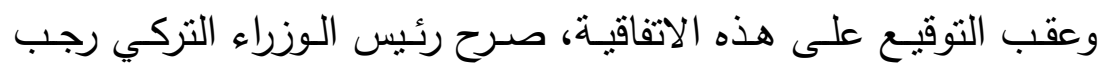

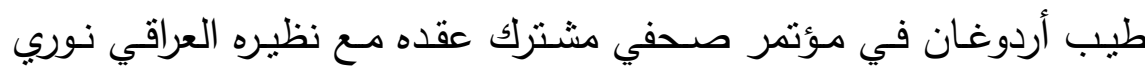

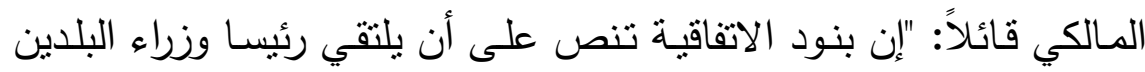

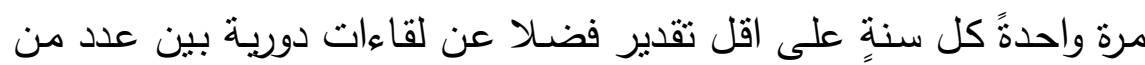

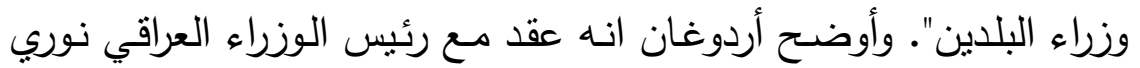

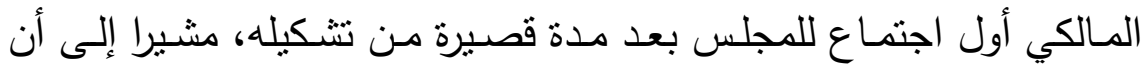

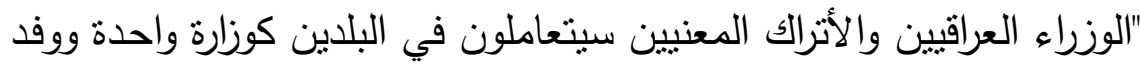
واحد للتخطيط للمستقبل المشترك للبلدين". وأكد على وجود إرادة مشتركة فئن قوية على أعلى المستويات لدعم الشراكة بين البلدين الجارين ضمن أهداف عاليـة للغايـة. وأضـاف أردوغان أن "تشكيل المجلس الأعلى سيحقق نتائج

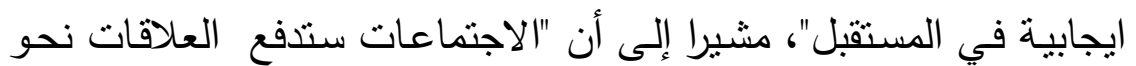
الأمام في المجالات السياسية والأمنية والطاقة والاقتصاد والثقافة ومصسادر المياه". وتوقع أن يبلغ حجم التبادل التجاري بين البلدين نهاية العام الجاري

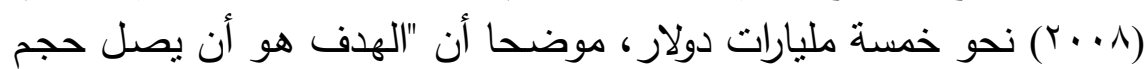

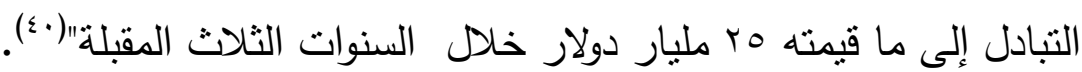

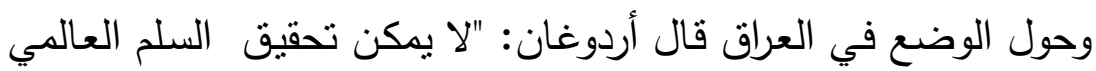
بدون تحقيق الأمن في العراق ويجب علينا جميعا مساعدة العراقيين في هذه 
المهمة ومساعدتهم في إعمار بلادهم" وأضاف: "أقول لجميع الدول الصديقة والجارة أن مستقبل العراق هو مستقبل المنطقة بأسرها فلابد أن نزيد دعمنا

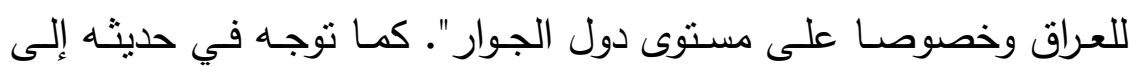

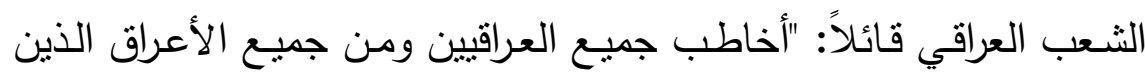

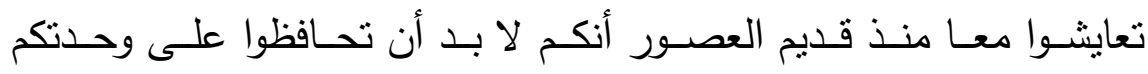

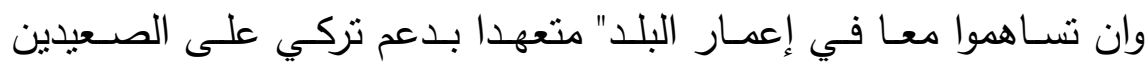

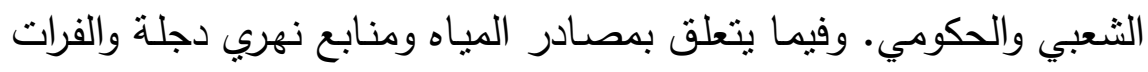

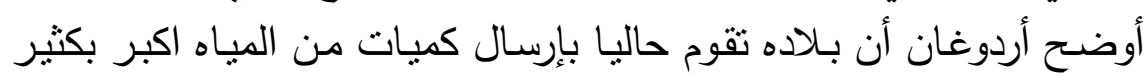

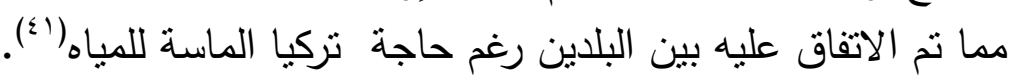

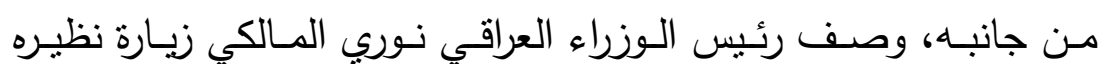

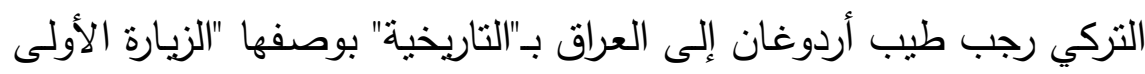
منذ ثمانية عشر عاما، وتفتح صفحة جديدة في العلاقات" بين البلدين. وقال

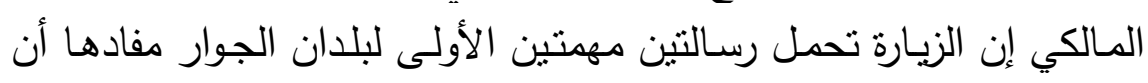

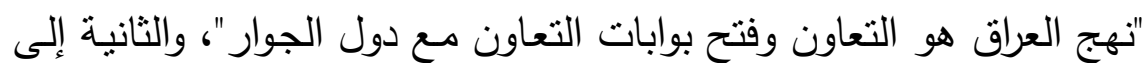

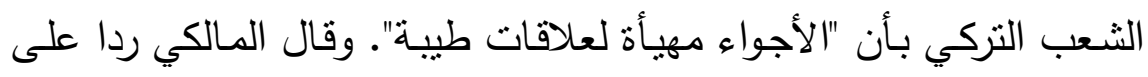

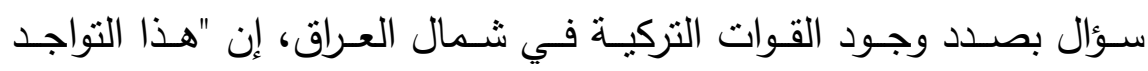

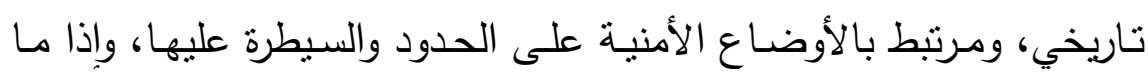

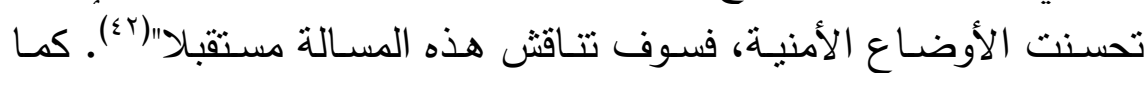

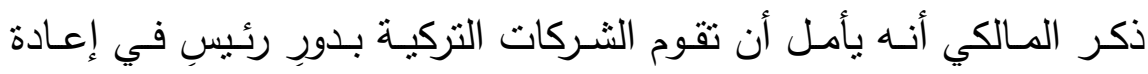

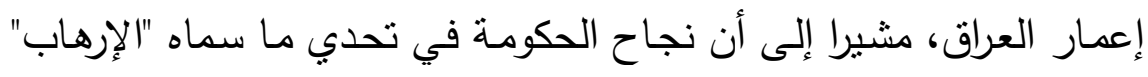

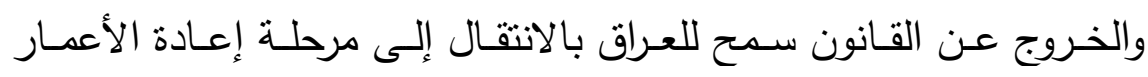
والاستثار (r) ونز

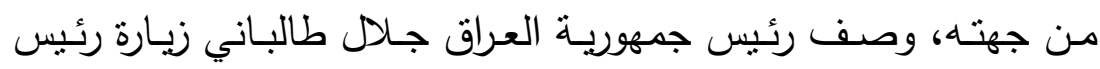

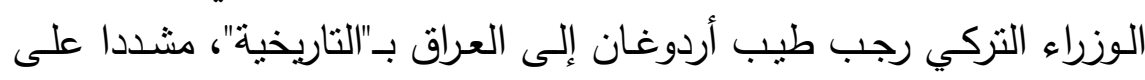

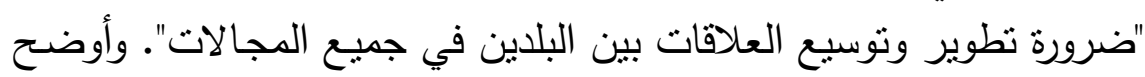


بيان صدر عن رئاسة الجمهورية العراقية أن الرئيس جال الطالباني "أجرى

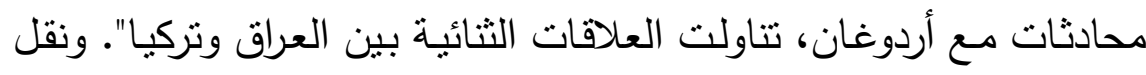

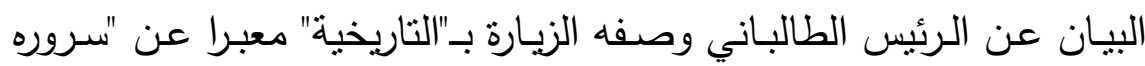

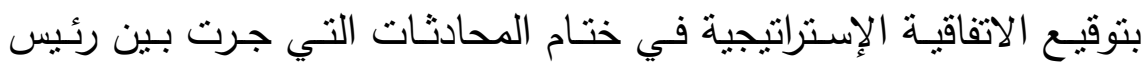

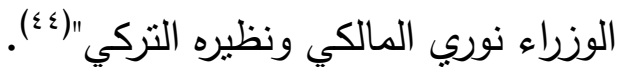
وقد اجتمع أردوغان بالرئيس العراقي ونائبيه عادل عبد المهدي وطارق الكان

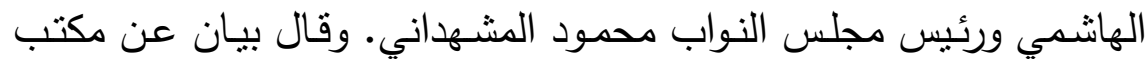

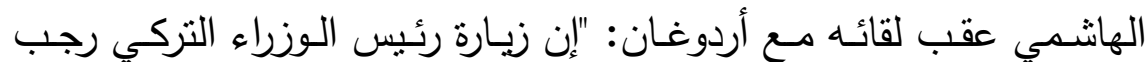

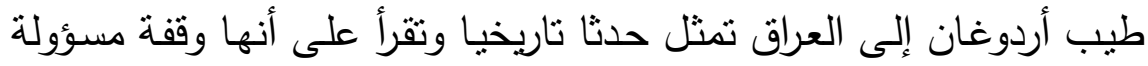

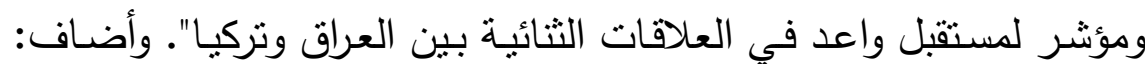

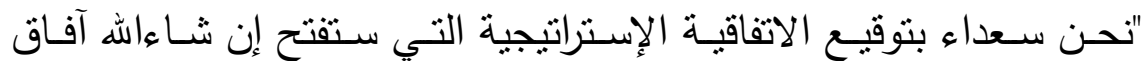

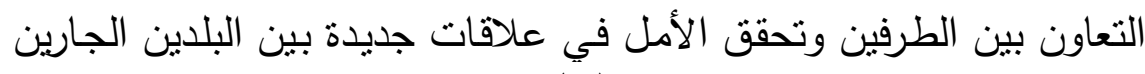

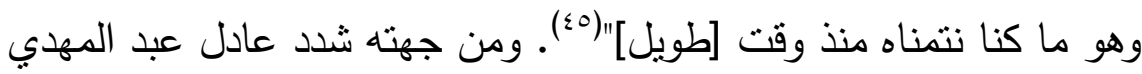

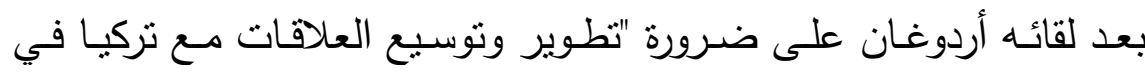

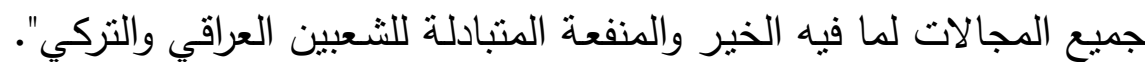

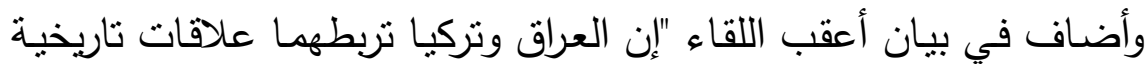

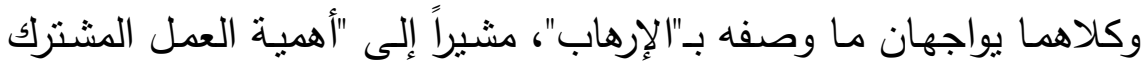

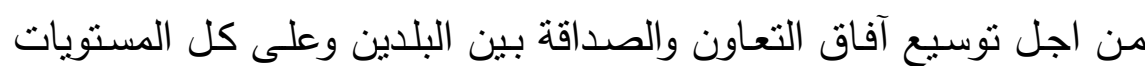

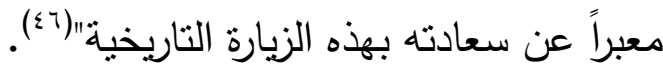
نــص الإعـلان السياســ المشـترك لتأسـيس المجلـس الأعلـى للتعـاون

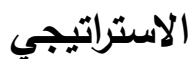
التويجا لمذكرة التفاهم المشترك الموقعة بين رئيس الوزراء العراقي نوري

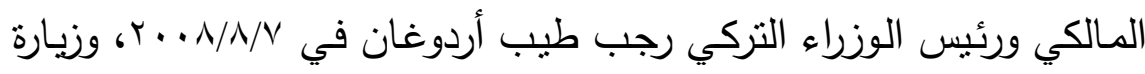

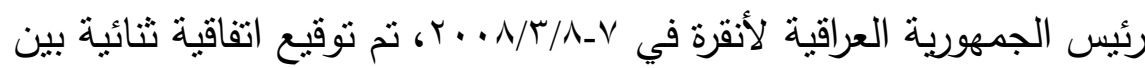


العراق وتركيا لتشكيل المجلس الأعلى للتعاون الاستراتيجي بين البلدين في

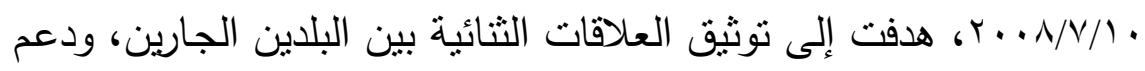

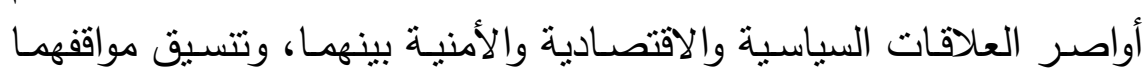

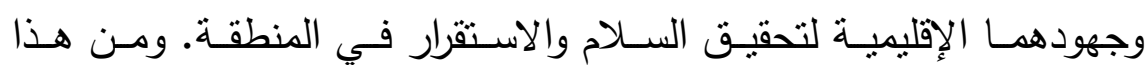
المنطلق، تلتزم حكومتا جمهوريـة العراق والجمهوريـة التركية بتطوير شراكة التهية

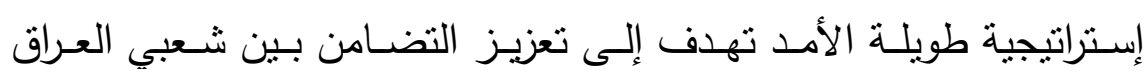
وتركيا(\&v)

وسيرأس هذا المجلس رئيسا وزراء البلدين، ويقوم وزيرا خارجيتهما بتتسيق

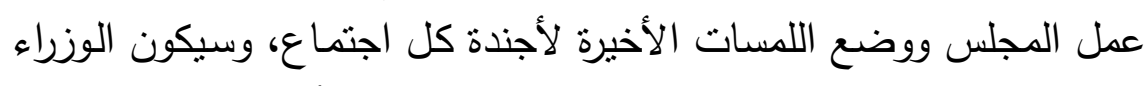

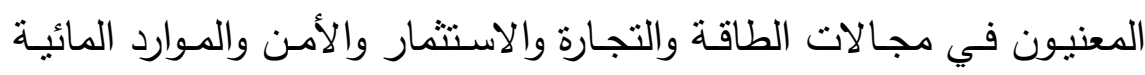

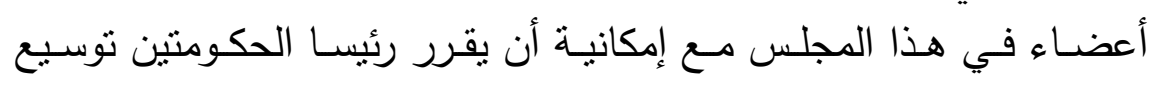

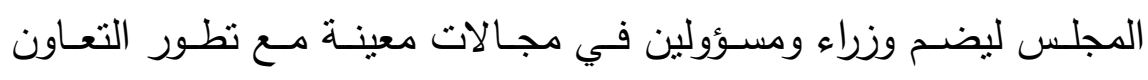

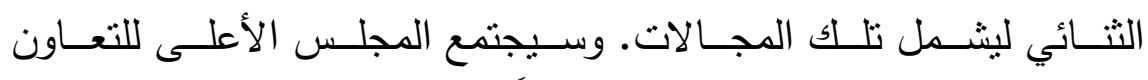

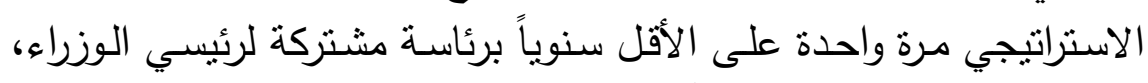

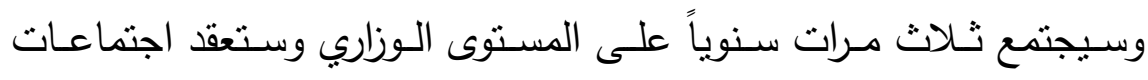
رسمية رفيعـة المستوى مرة كل ثلاثة أثـهر في عاصـتي البلدين. وسيتم تطوير خطط عمل عن طريق الوزراء المعنيين لتسريع التعاون ضمن نطاق

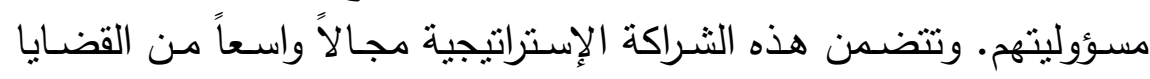

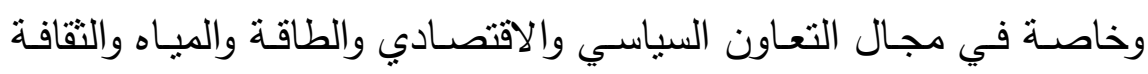
والتعاون الأمني والعسكري على أساس المبادئ التالية(^)؛

أ- المجالات السياسية واللابلوماسية وإلثقافية

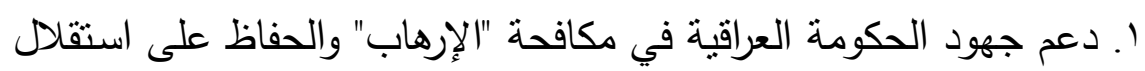

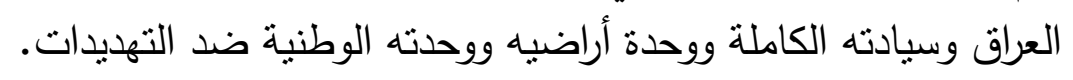


r. عقد اتفاقيات ثثائيسة بوقت قصسير ومحدد للمسـاعدة في تأسيس روابط أقوى بين البلدين. r. التأكيد على التزامات دول الجوار وكذلك اجتماعات دول الجوار الموسعة في دعم الحكومـة العراقية في جهودهـا لتحقيق أهداف الثـعب العراقي من أجل عراق حر، مستقل، موحد، إتحادي، ديمقراطي ومزدهر .

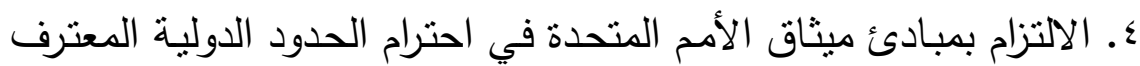

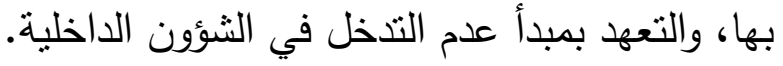

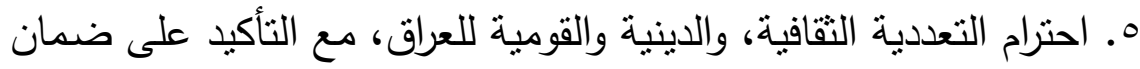
احترام التعايث السلمي لجميع المكونات واحترام الهوية العراقية دن أجل مستقبل العراق. 7. تشـجيع برامج التبـادل الدبلوماسـي والتقافي والتربوي والعلمسي للمـوظفين الحكوميين والطلبـة بين البلدين وتطوير التعـاون بين المؤسسـات في حقول التعليم العالي والتكنولوجيا والمعرفة التقنية.

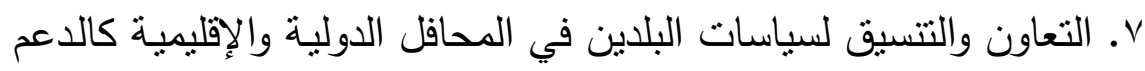

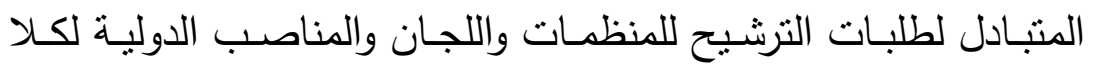
البلدين.

\section{ب- المجالات المتعلقة بالاقتصاد والطاقة}

1. عقد اتفاقيات للتعاون والتكامل الاقتصادي الاستراتيجي بين البلدين قبل والطاده

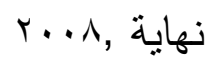

r. تشـجيع التعـاون الرامسي إلى تنشـيط السياحة وتشـهيل تتظيم الجـولات

$$
\text { السياحية بين البلدين. }
$$

r. تعزبـز التعـاون لتتميـة العلاقـات التجاريـة لتحقيـق المصـلحة المشـتركة لثعبي البلدين وعقد اتفاقية تجارة حرة بين العراق وتركيا من أجل تحقيق 
ء. التتشيع والعمل على برامج مشتركة لتأسيس مناطق تجارة وصناعة حرة

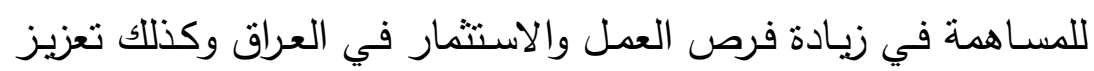

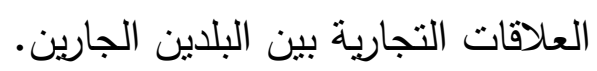

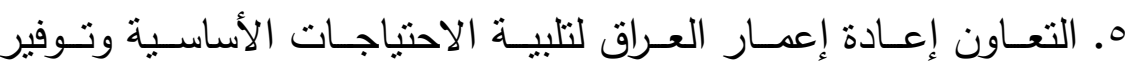

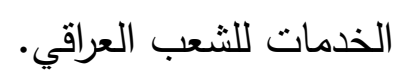

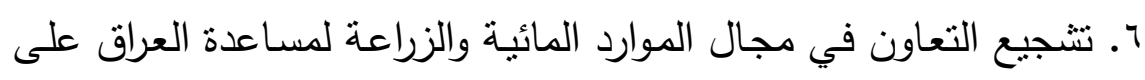

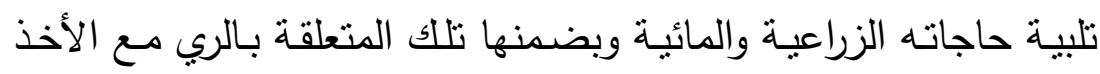
بنظر الاعتبار حاجة تركيا الزراعية والمائية على توفير تلائك المساعدات.

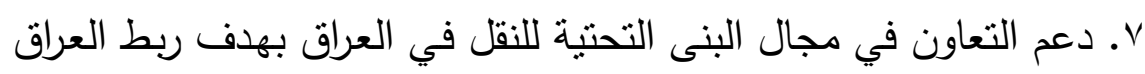
مع أوربا عبر تركيا.

^. تشجيع شركات القطاع العام والخاص لزيادة التعاون في مجال الاستثمار

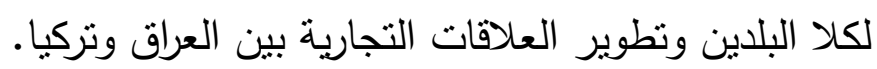

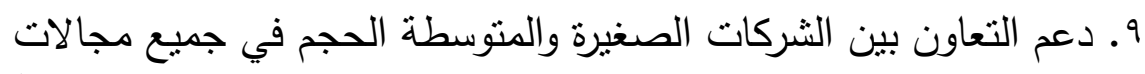

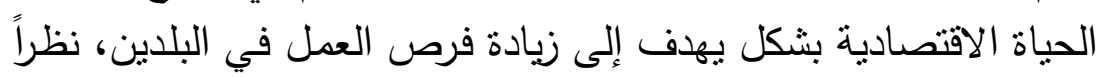

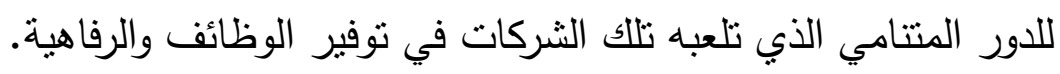

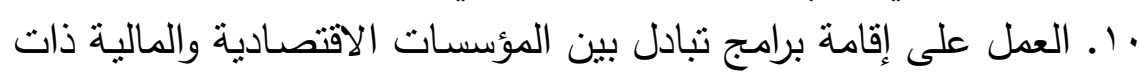

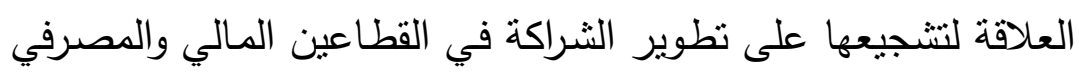
في البلدين. ا' ـ دعم التطور الاقتصادي في العراق من خلال برامج المساعدة في إطار جهوده للتحول إلى اقتصاد السوق.

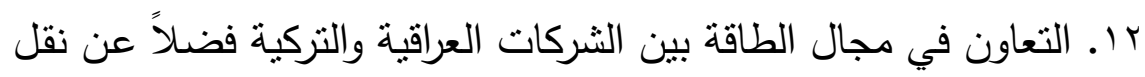

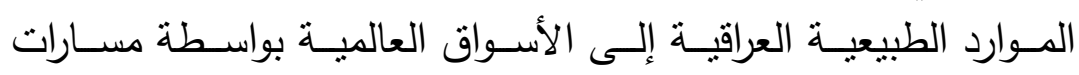

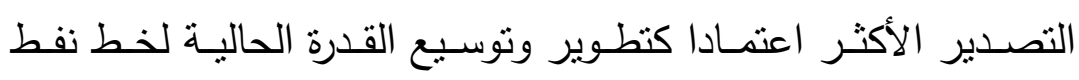

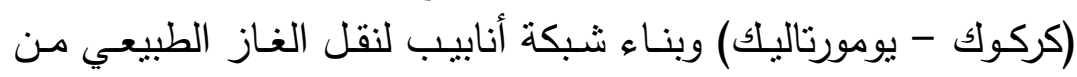
العراق إلى الأسواق الدولية عبر نركيا. 
سا ـ تحقيق المشاريع التي ستساعد العراق وتركيا في تأمين احتياجاتهما من

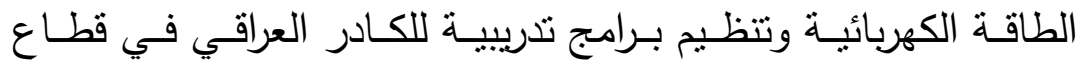

$$
\text { الكهرباء. }
$$

ع ا ـ الإسراع بفتح بوابات حدودية جديدة بين العراق وتركيا.

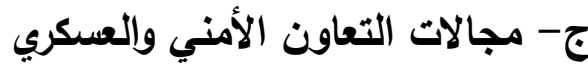

ا. احترام أمن أراضـي كل مـن البلدين للآخر ، ودعم جهودهمـا المشتركة

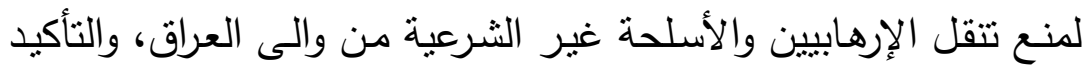

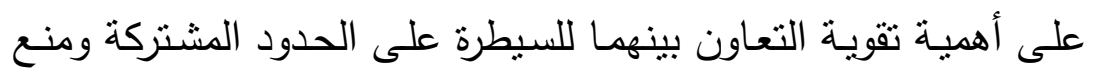

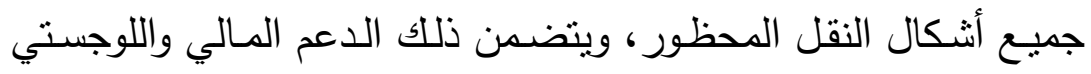
وكل أشكال الدعم الأخرى للإرهابيين والمنظمات الإرهابية وكذللك رفض التض استخدام اللغة المشجعة على العنف والإرهاب. r. إتمام الاتفاقية الإطارية العسكرية بين رئيسي أركان البلدين.

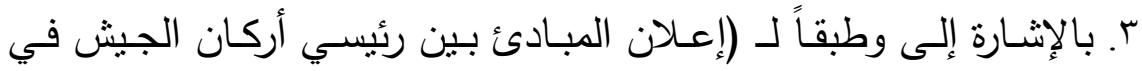

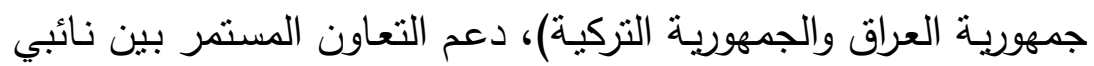

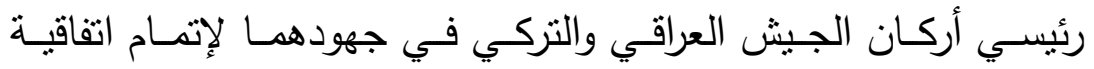
التعاون العسكري لتدريب وتعليم الضباط العراقيين. ع. إتمام إجراءات اتفاقية محاربة الإرهاب بين جمهوريـة العراق والجمهورية التية التركبة. ๑. تطوير العلاقات التجارية والاستثمارات المتعلقة بالصناعات الدفاعية من

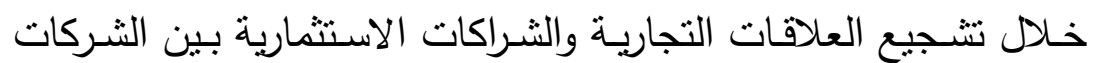
العامة والخاصة لكلا البلدين (9؛). وفي سياق التعاون العراقي - التركي في المجال الأمني، وتحديداً حول

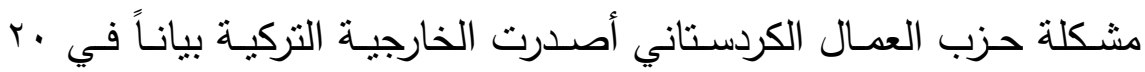

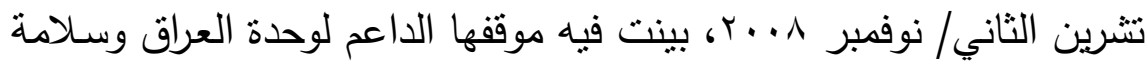


أراضيه، وآفاق التعاون الأمني بين العراق وتركيا جاء فيه: "تولي تركيا

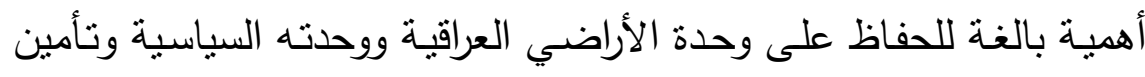

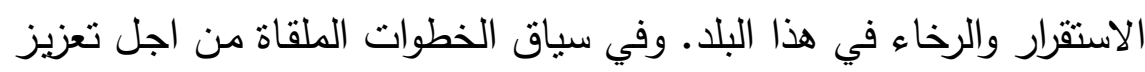

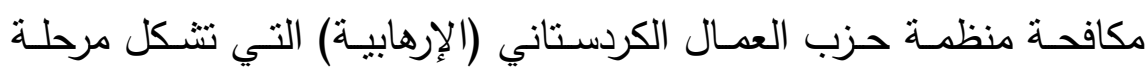

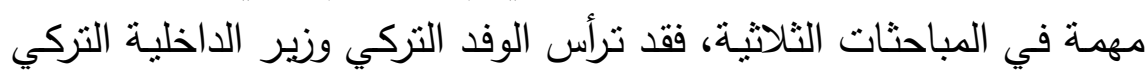

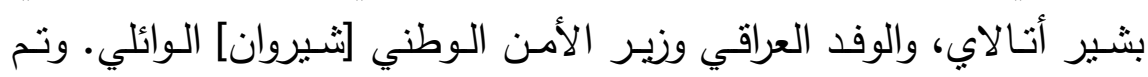

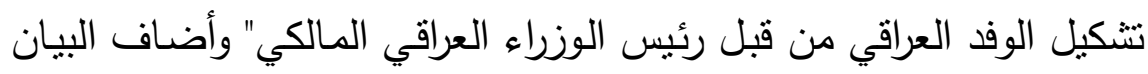

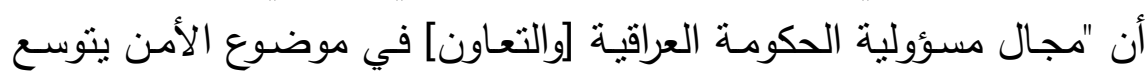

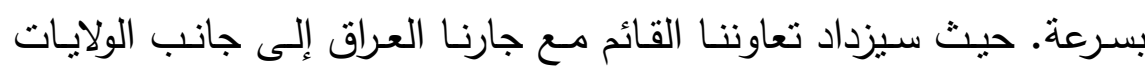

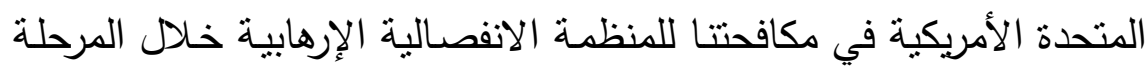
اللاحقة"(•).

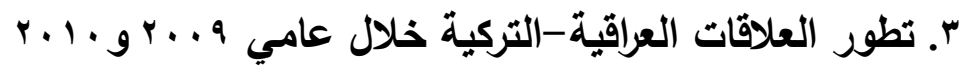

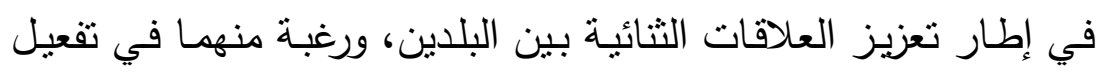

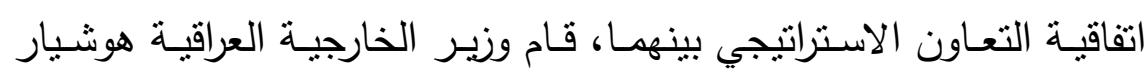

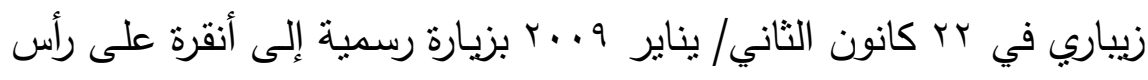

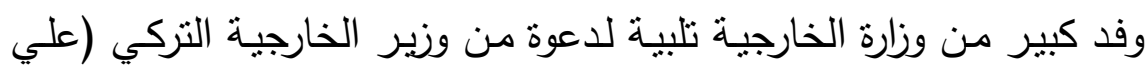

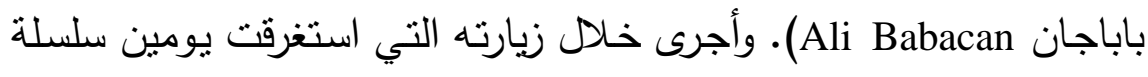

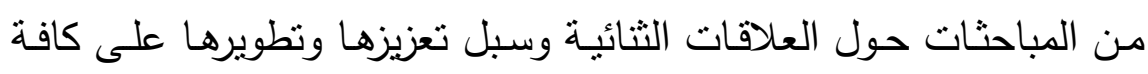
المستويات، والتنسيق المشترك لتنفيذ الإعلان الاستراتيجي للعلافات اتهات الثنائية

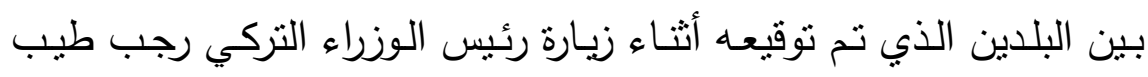

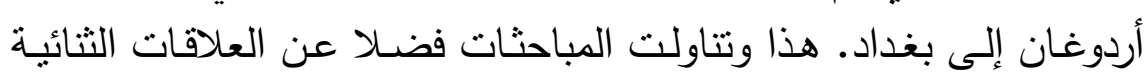
الأوضـاع في المنطقة وخاصـة أمن الحدود المشتشركة ومكافحسة (الإرهاب)

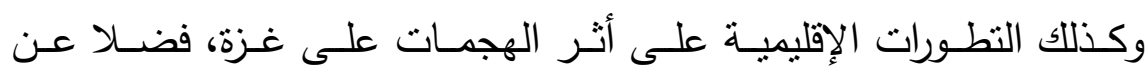


الأوضـاع الدولية وأهيـة التعاون والتتسيق بين العراق وتركيا في المحافل الإقليمية والدولية (10). وفي خطوة تركية مقابلة في إطار تبادل الزيارات الرسمية بين مسؤولي

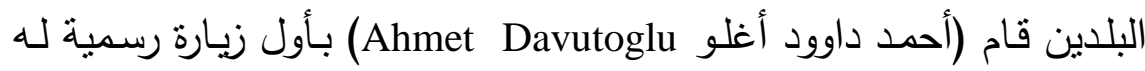

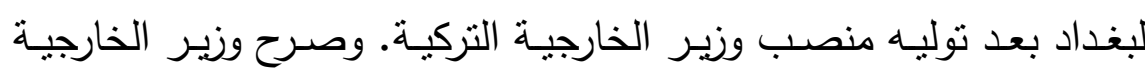

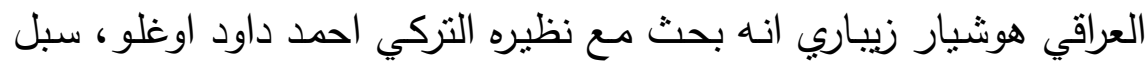

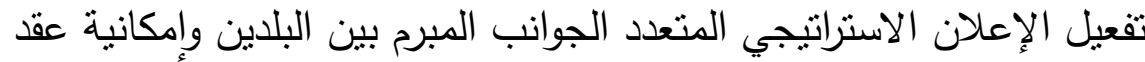

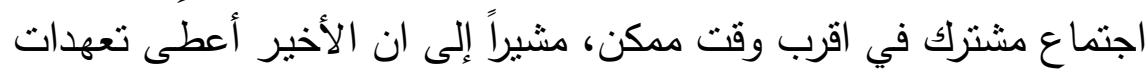

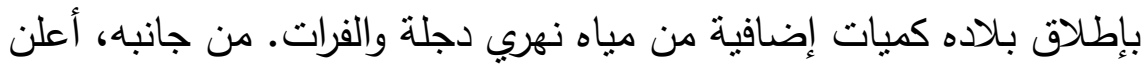

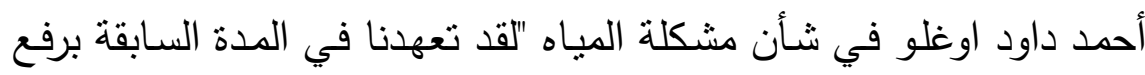

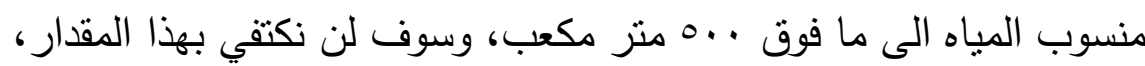

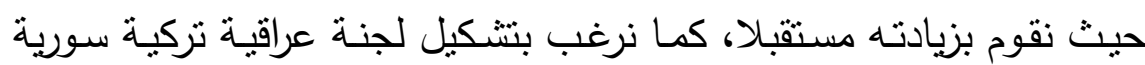

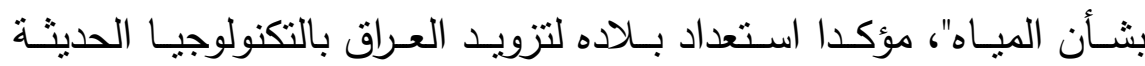

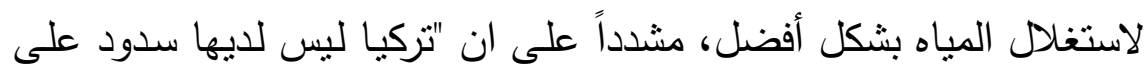

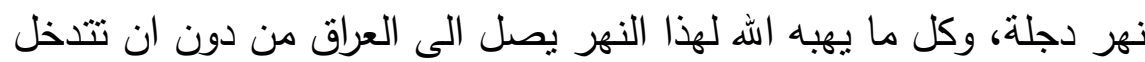

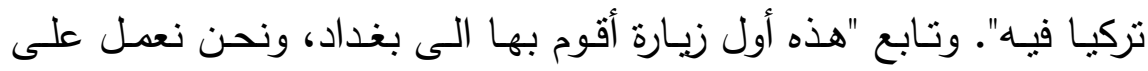
تتكيل علاقة نموذجية معه"، واصفا الروابط بين البلدين من حيث التنـابك بأنها "تشبه علاقة الاظفر باللحم"(or). في الحقيقة إن تصريحات وزير الخارجية التركي فيما يتعلق بعدم إقامة تركيا سدوداً على نهر دجلة ليست دقيقة لو لوحت صحت من المصدر مثل هذه

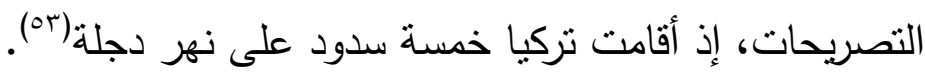

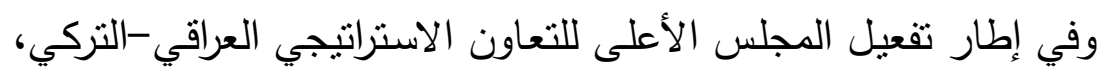

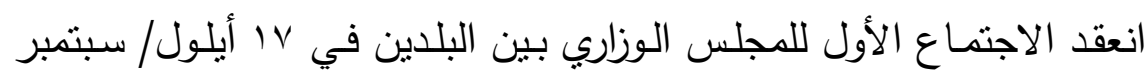

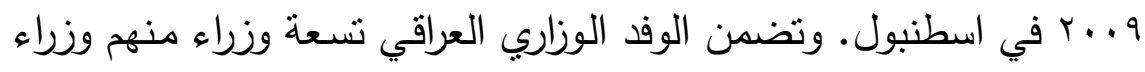
الخارجية والدفاع والداخلية والتجارة وغيرهم. وصرح وزير الخارجية التركي لـوني 
أحمد داوود أوغلو الذي كان يتحدث في الجلسة الافتتاحية للاجتماع الأول

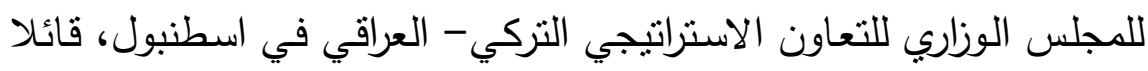

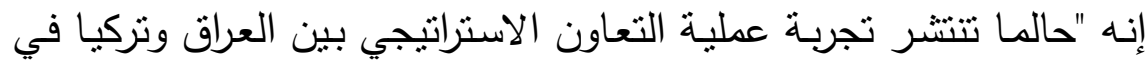

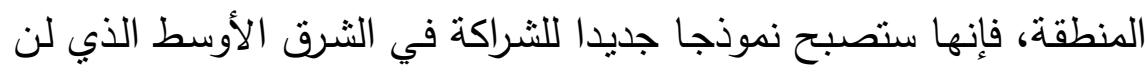

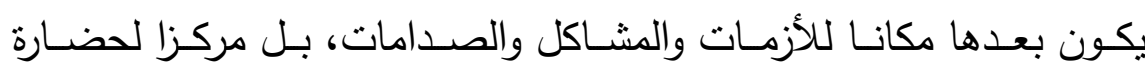

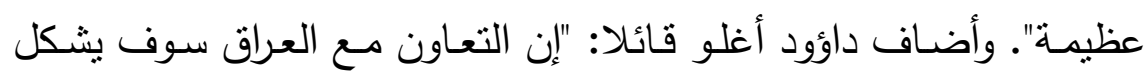

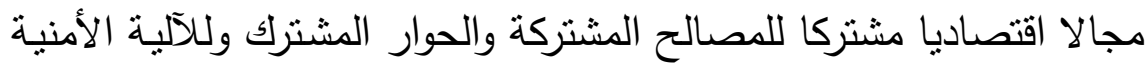

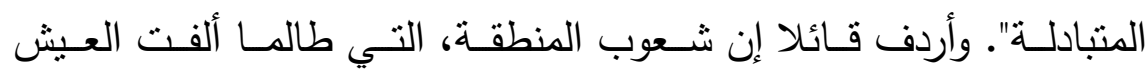

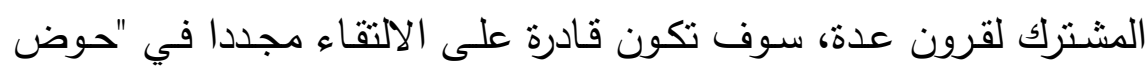

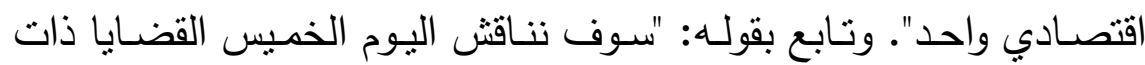

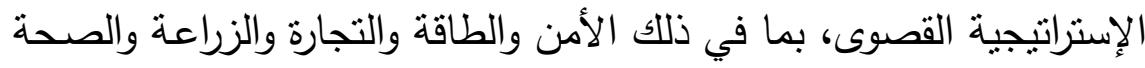

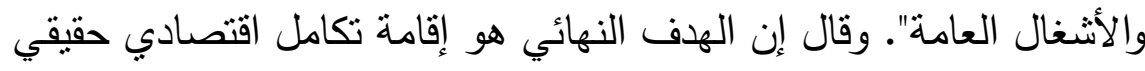

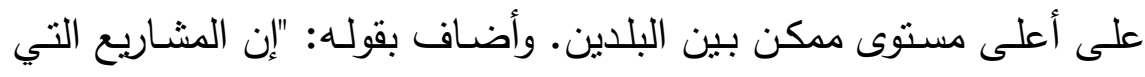

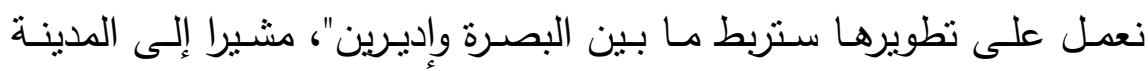

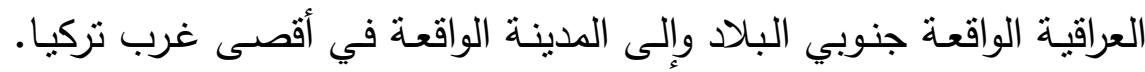

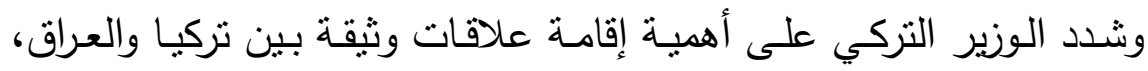

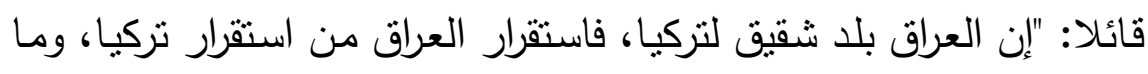

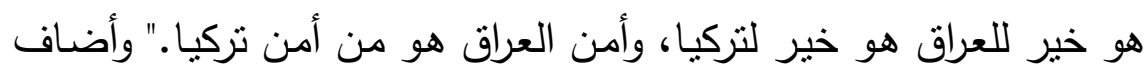

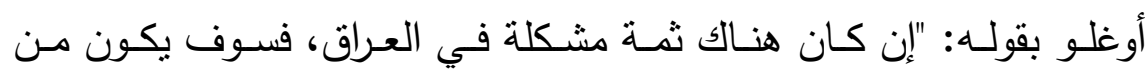

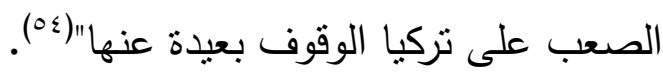

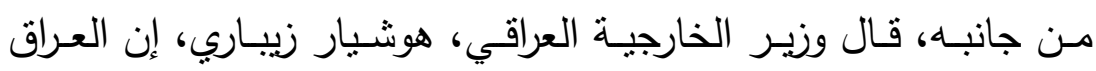

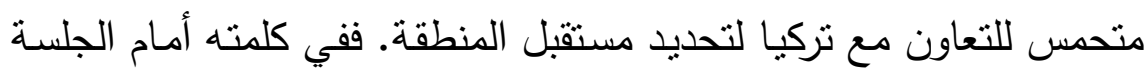

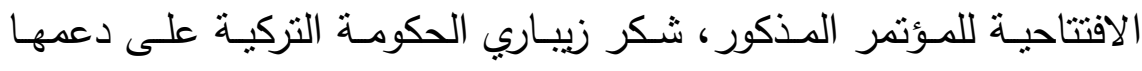

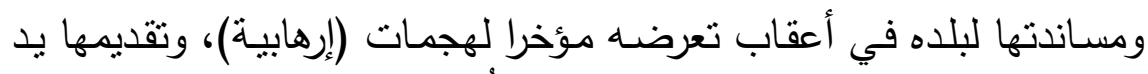

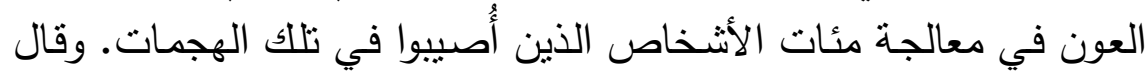


زيباري: "إن ثمـة إرادة قوية برزت من أجل تحقيق المزيد من التعاون بين

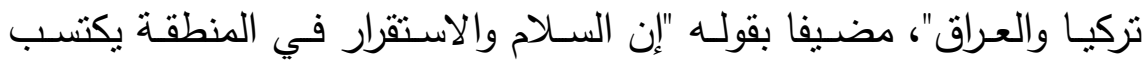
أهمية قصوى، ليس فقط بالنسبة لتركيا والعراق فحسب، بل للمنطقة بردية برمتها".

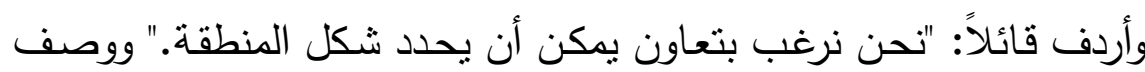

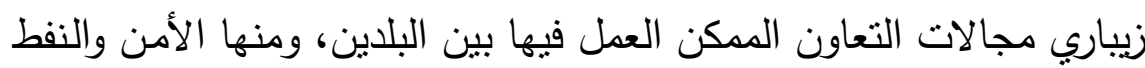

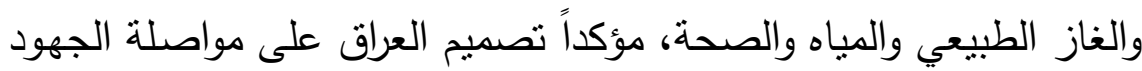
لتحويل تلأك الإرادة إلى واقع ملموس (100).

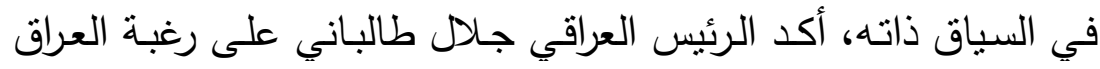

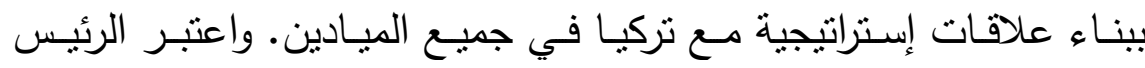

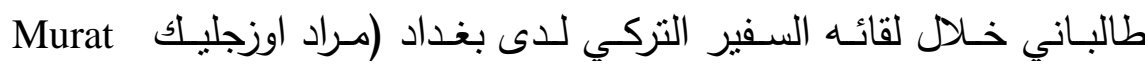

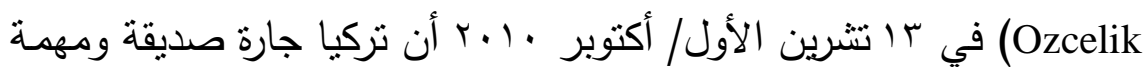

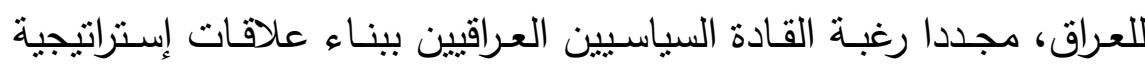

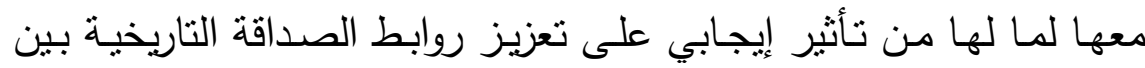

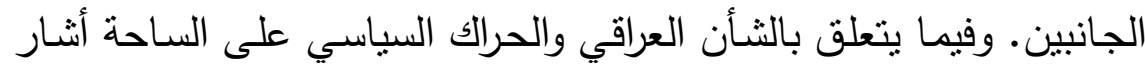

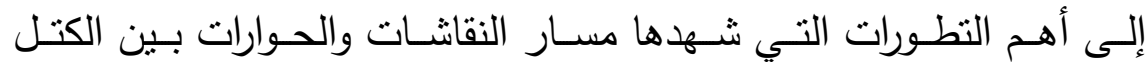

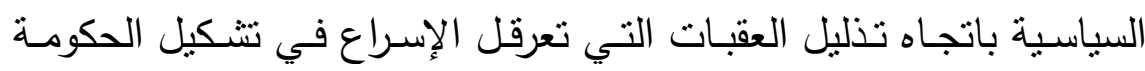

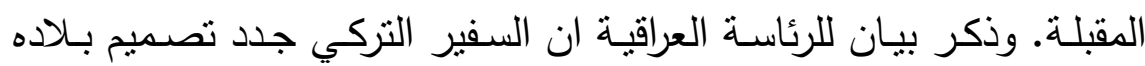

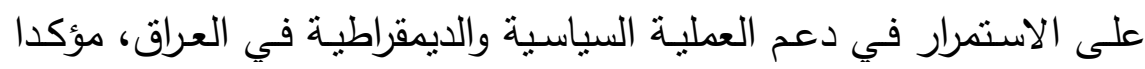

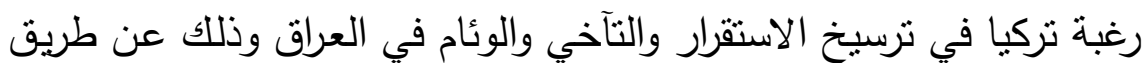

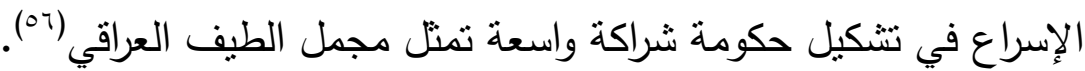

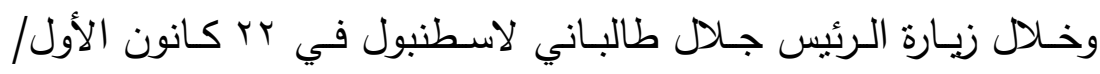

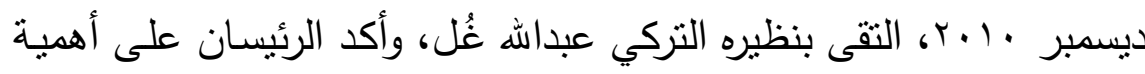

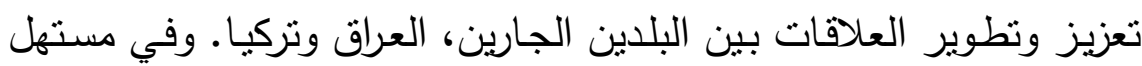

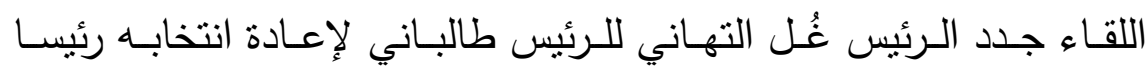

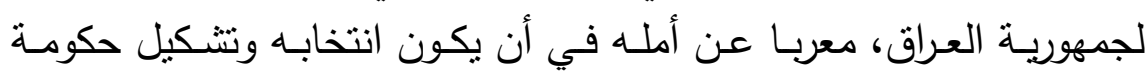




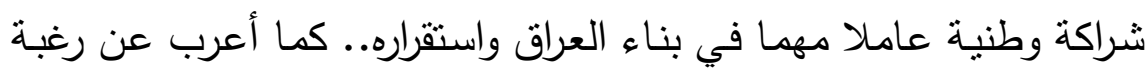

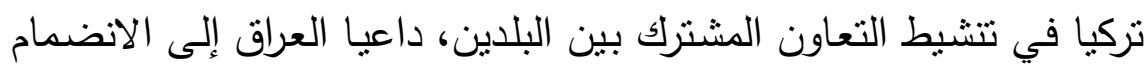

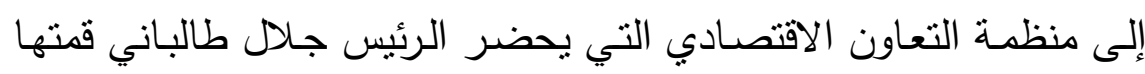

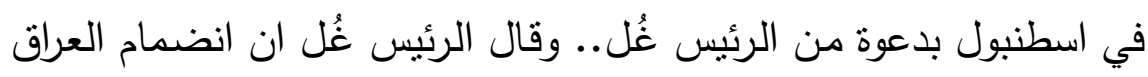

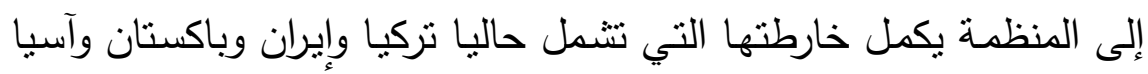

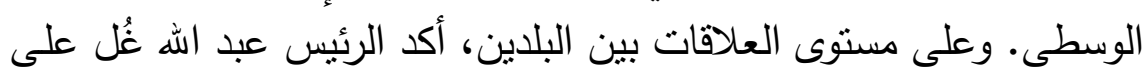

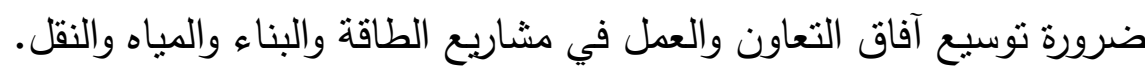

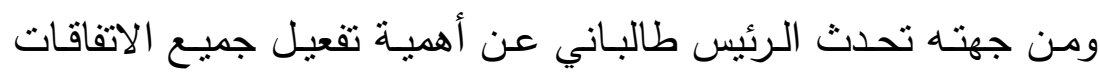

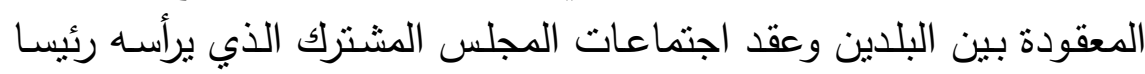

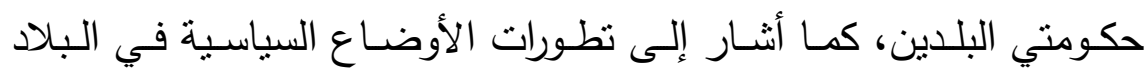

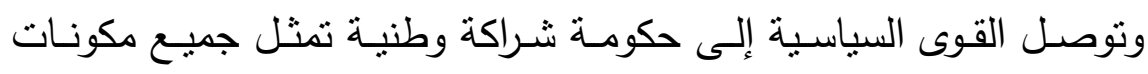

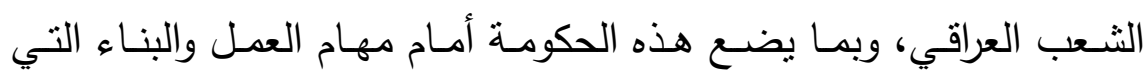

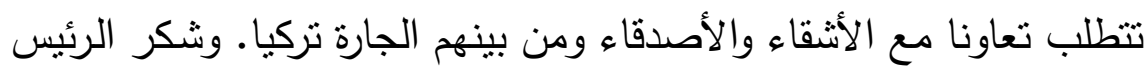

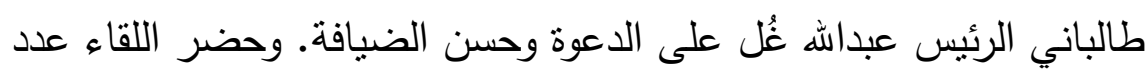

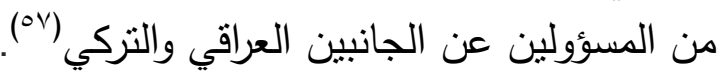

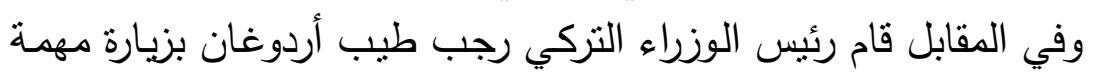

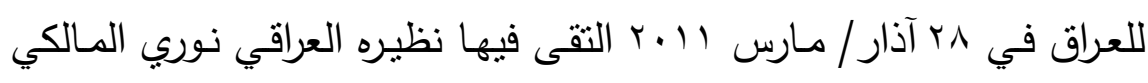

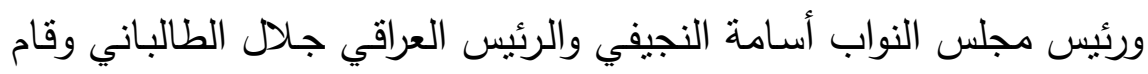

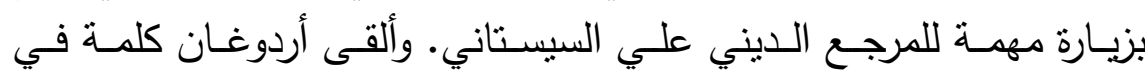

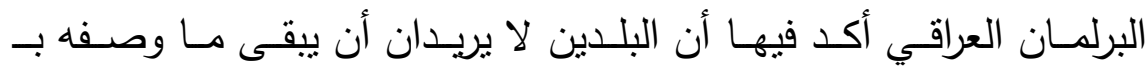

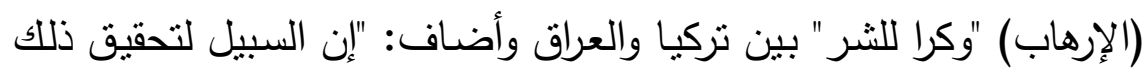

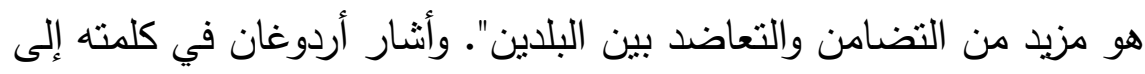
العديد من النقاط كما يأني: - وققنا إلى جانب الأخوة العراقيين في كل مناسبة وقان وقدمنا دعمنا في كل

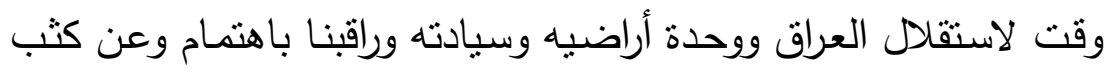


حالات الأمن والاستقرار فيه ووقفنا دوما على مسافة منساوية من جميع الطوائف والفصائل السياسية العراقية. - نريد أن نرى العراق قوياً موحداً مستقراً بـلا عنصرية ولائ طائفية ونريده أن يكون جزءاً من السلام في المنطقة. - إن البرلمان التركي مستعد لأن يتقاسم خبراته مـع مجلس النواب العراقي

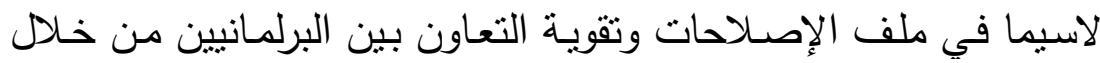

$$
\text { لجان الصداقة. }
$$

- نشعر بالفخر والاعتزاز عندما نرى مسيرة العراق الديمقراطية تتقدم بخطى

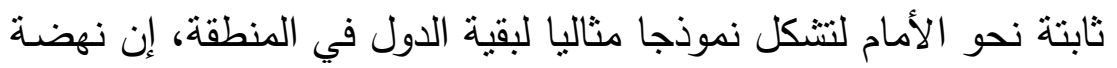

$$
\text { العراق تعني نهضة كل الدول الإسـامية. }
$$

واختتم أردوغـان خطابـه بقراءة النشـيد الـوطني العراقي باللغـة العربيـة الفصحى وهو الأمر الذي قوبل بعاصفة قوية من التصفيق من قبل أعضاء مجلس النواب كما ألقى كلمـة مطولة تغزل فيها بتاريخ بغداد وتعهد بمزيد

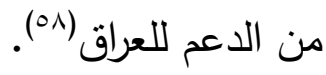

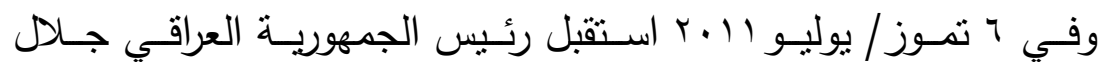

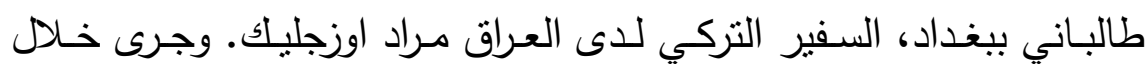

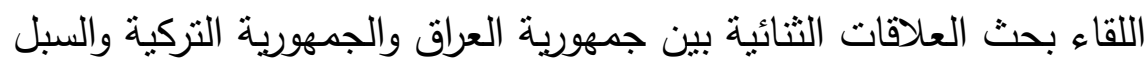

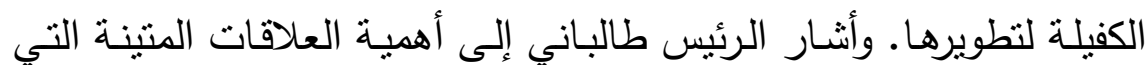
تـربط البلدين الجـارين، مؤكدا ضـرورة توسـيع هذه العلاقـات لتشـمل كافـة

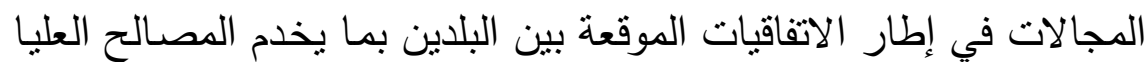

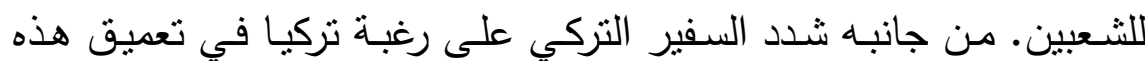

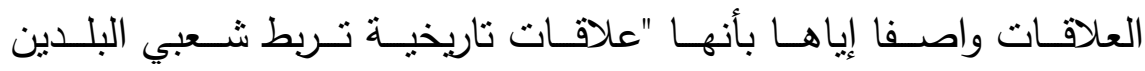

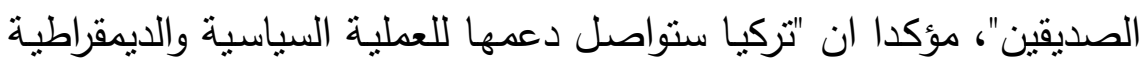
وان الاستقرار في العراق مهم بالنسبة إلى تركيا"(09). 


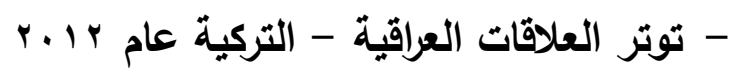

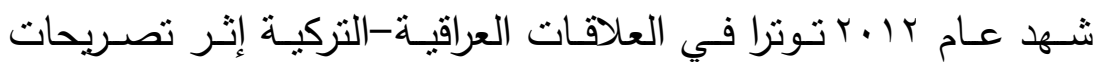

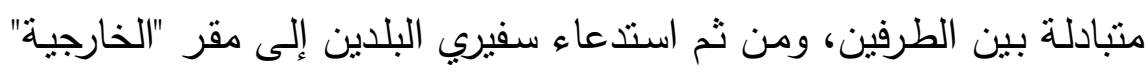

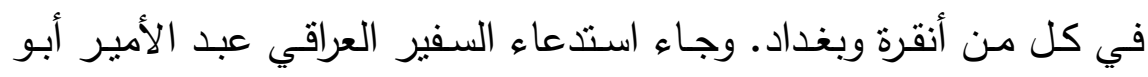

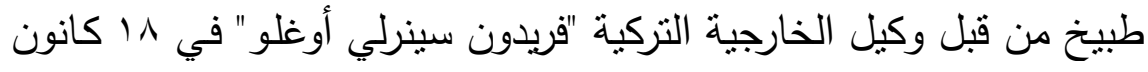

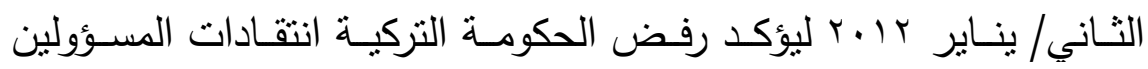

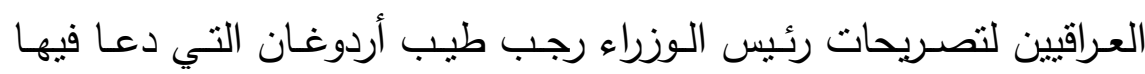

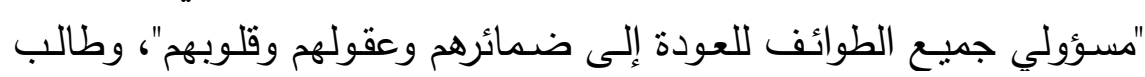

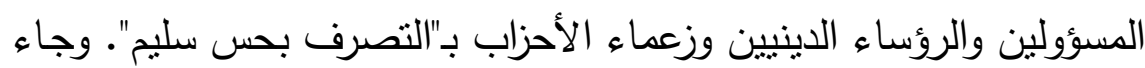

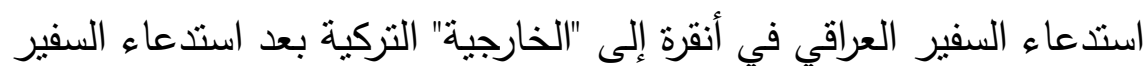

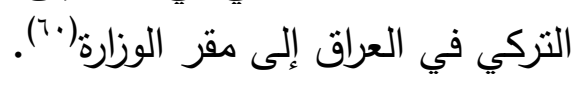

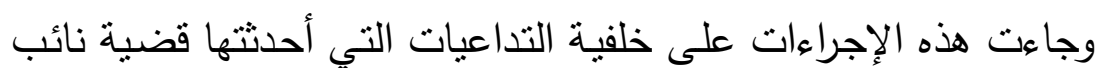

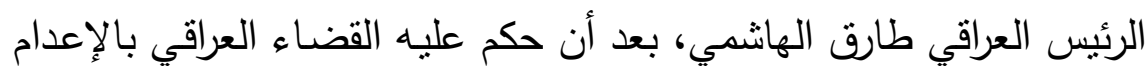

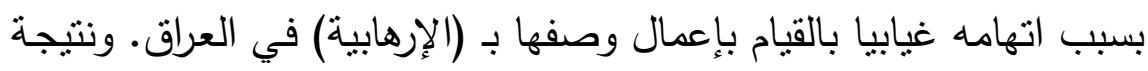

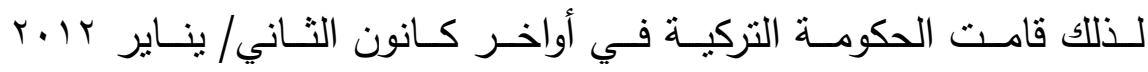

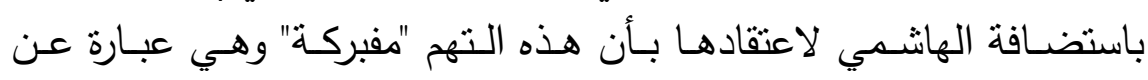
"استهداف سياسي" للرموز الوطنية العراقية.

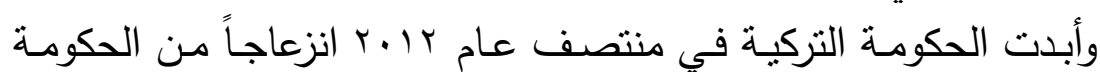

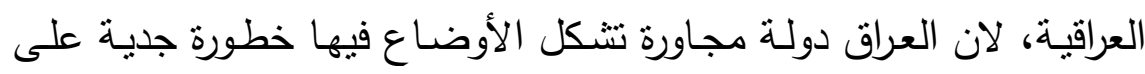

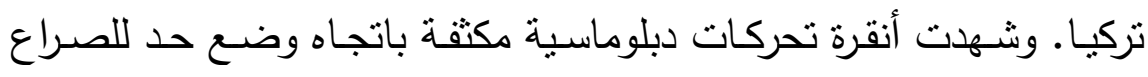

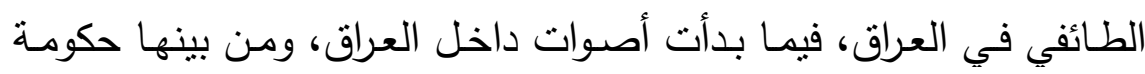

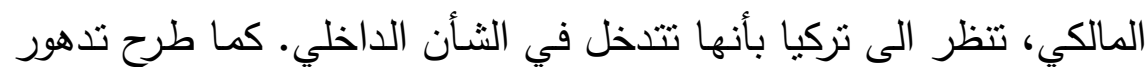

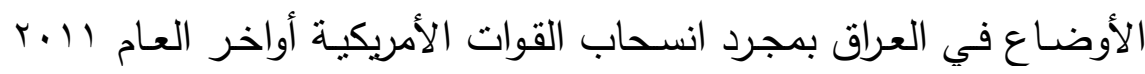
على خط الدبلوماسية التركية خلا لالدرد المدة الماضية. 
- انعكاسات الأزمة السورية على العلاقات العراقية-التركية

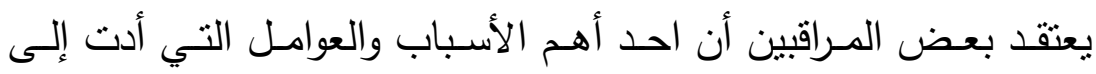

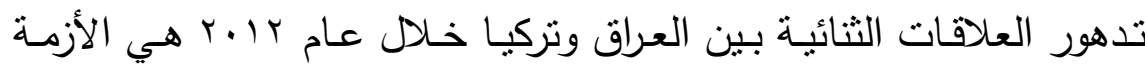

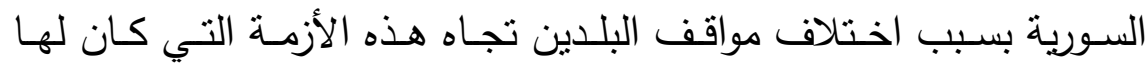

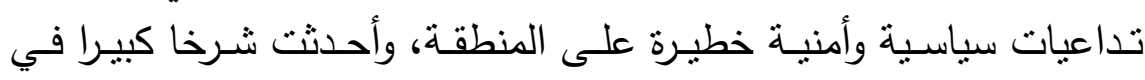

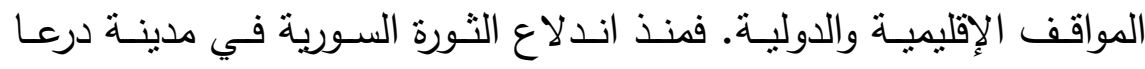

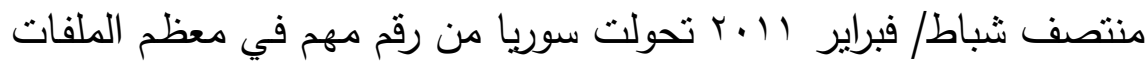

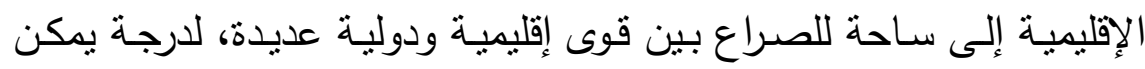

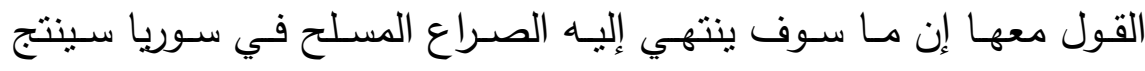

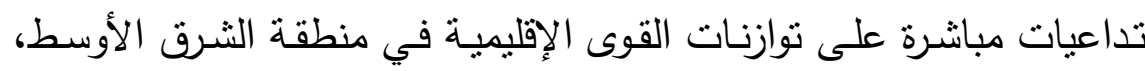

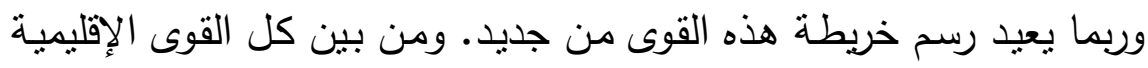

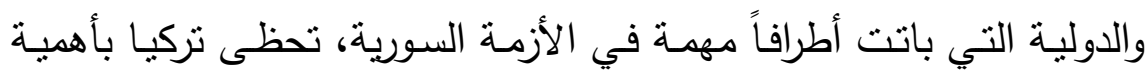
وموقع خاص، ليس فقط بسبب احتضانها لقوى المعارضة السورية، المسلحة

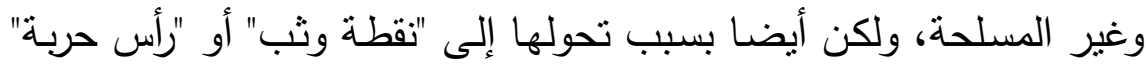

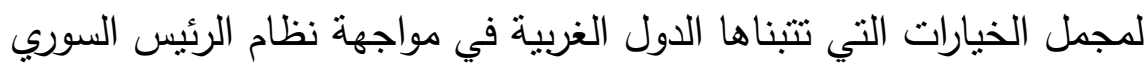

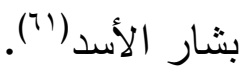

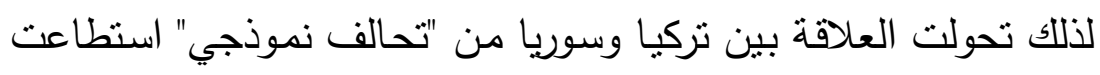

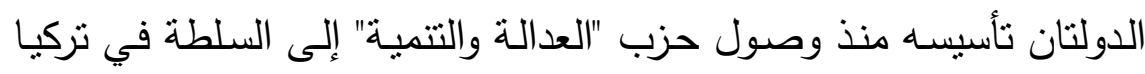

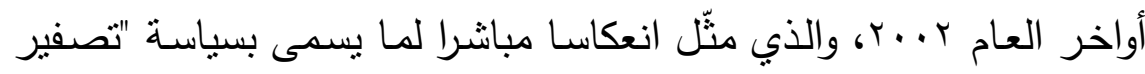

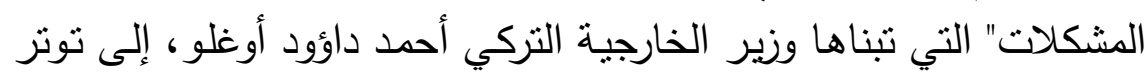

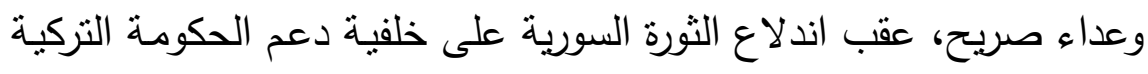

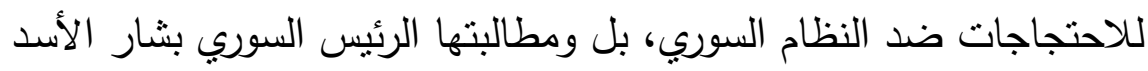

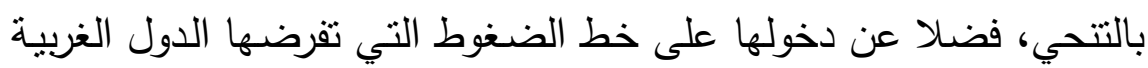
على هذا النظام (ז'). 
من جهته أختلف العراق مـع تركيا في موقفه من الثورة السوريّة، التي

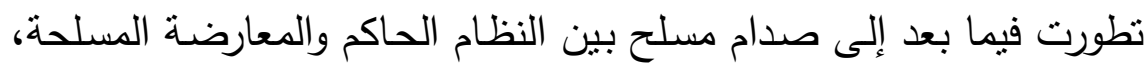

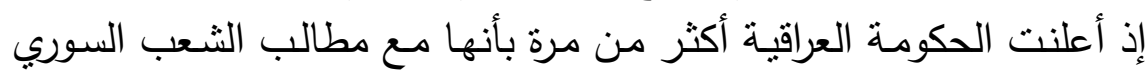

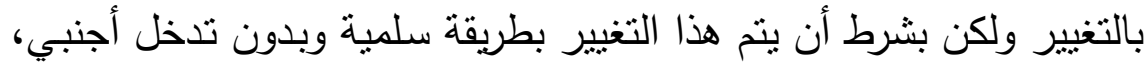

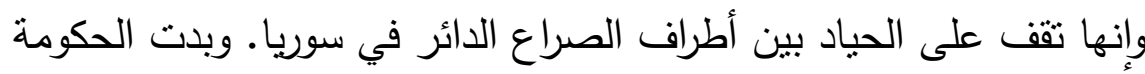
العراقيـة أقـل تحمسـاً للثتورة السـورية مقارنـة بمواققهـا مـن الثورات الثـعبية الأخرى في تونس ومصر وليبيا واليمن، أو على الأقل حذرة جداً في أي

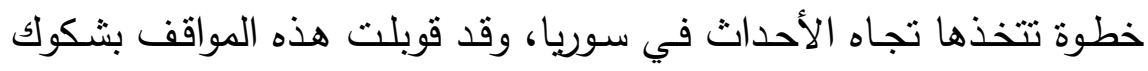

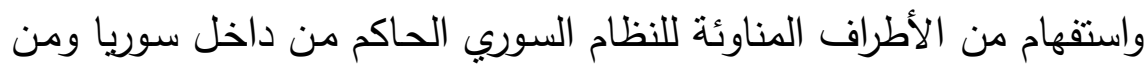
خارجها. ولكن الحكومة العراقية هي الأخرى لديها شكوكها وتحفظاتها على لإنى

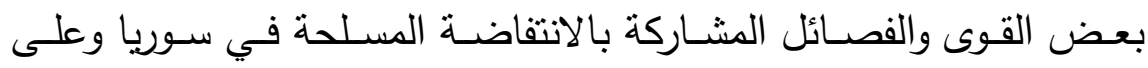
توجهاتهم الفكريـة وأهدافهم بعيدة المدى. وقد أوضتح هوشيار زيباري وزير

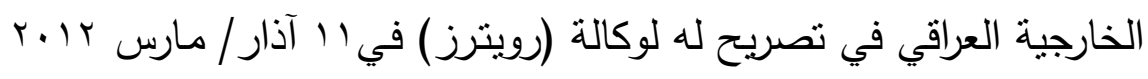

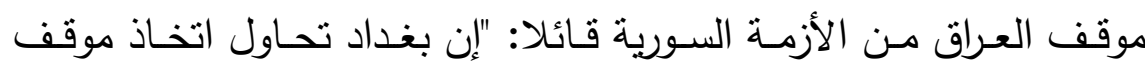

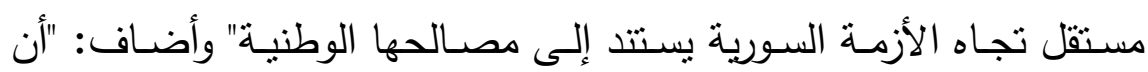
العراق يحاول أن يكون موقفه مما يجري في سوريا مختلف عن غيره وأن الاختيارات ليست بالضرورة أن تكون إما أبيض أو أسود" ("جآ.

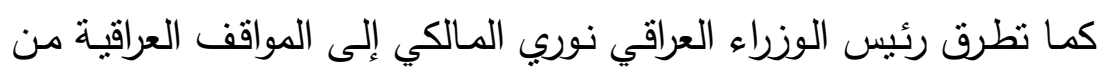

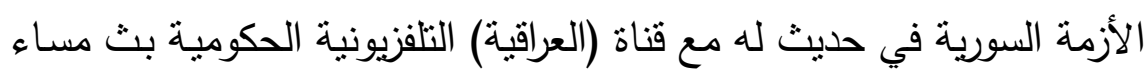

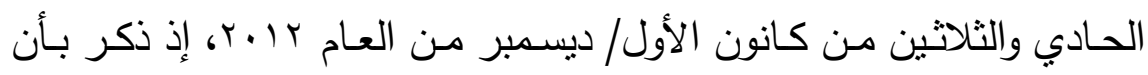

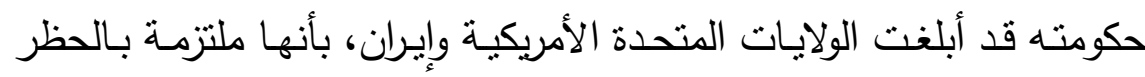

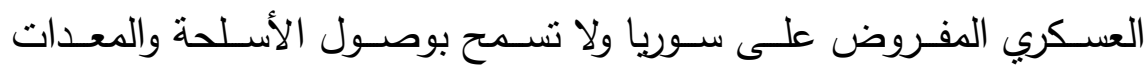
العسكرية لأي طرف في الصراع داخل سوريا ومن أية جهة كانت، ولكنها في

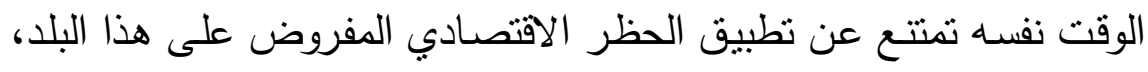

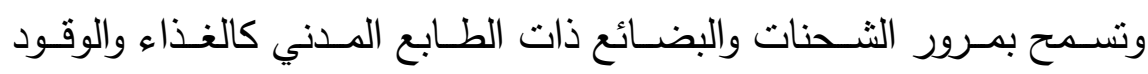




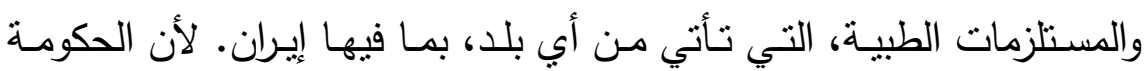

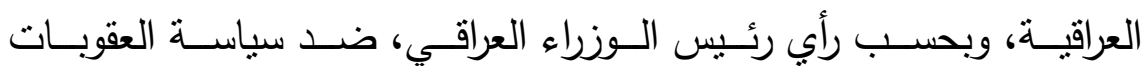
الاقتصادية التي تفرض على البلدان بهدف الضغط على الأنظمة الحاكمة،

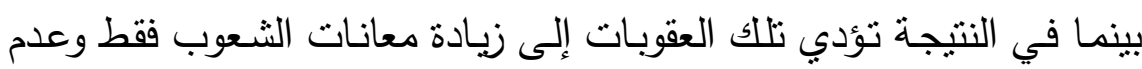

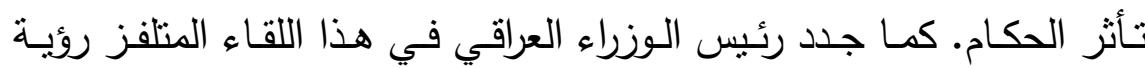

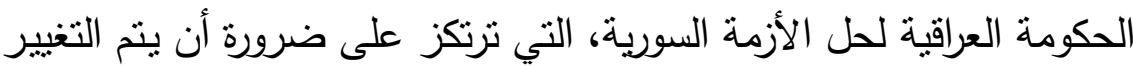

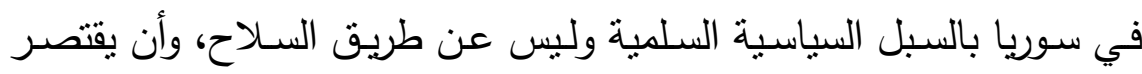

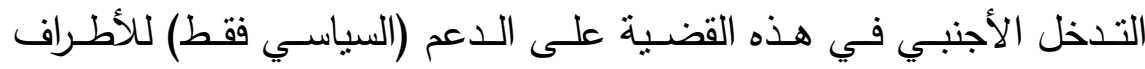
(المتندلة فقط). وفيما يتعلق بالتوتر الحاصل في العلاقات العراقية ـالتركية ذكر رئيس

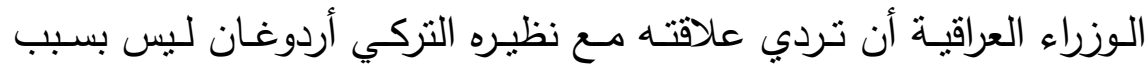

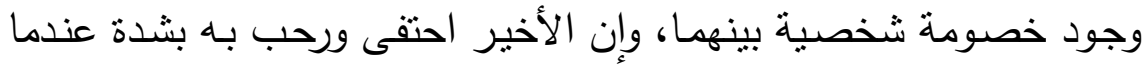

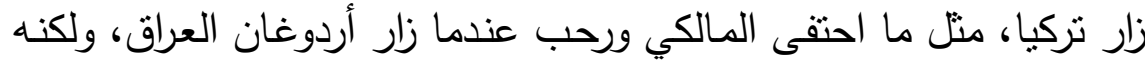

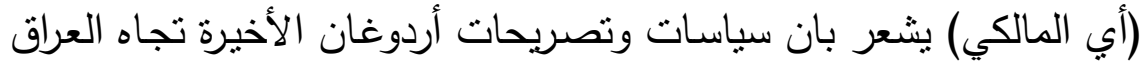

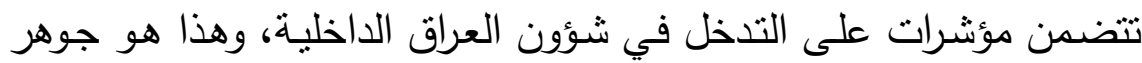

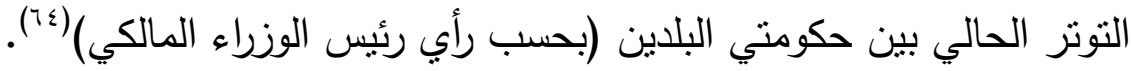

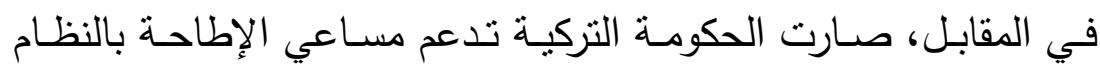

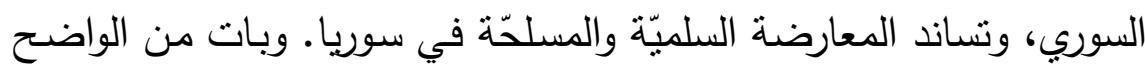

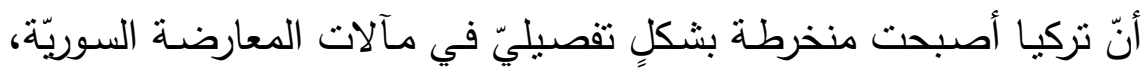

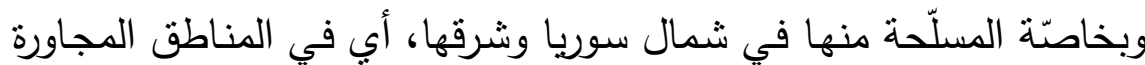

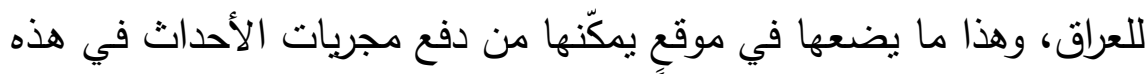

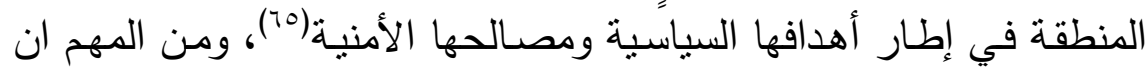

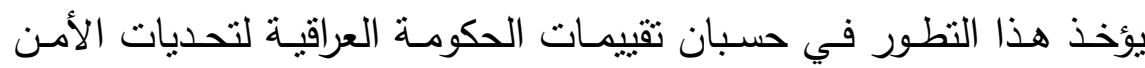

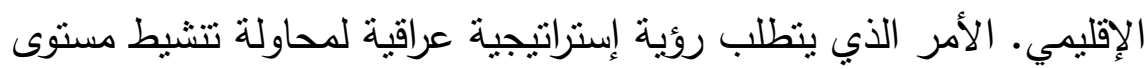
معين من العلاقات الأمنية مع تركيا بغض النظئر النظر عن الحالة المتردية حالياً 


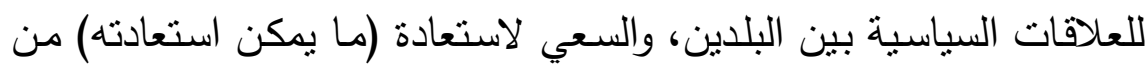

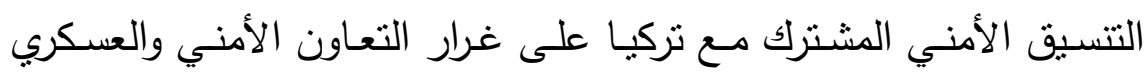

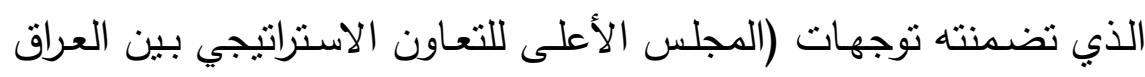

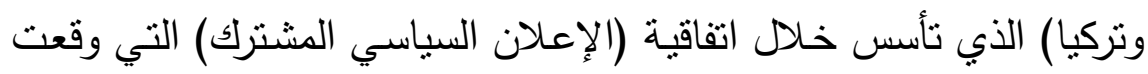

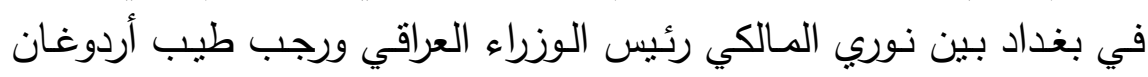

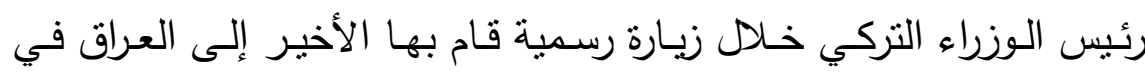

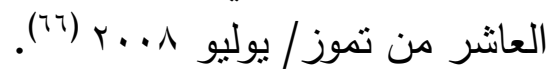

\section{خاتمة: استنتاجات وتوصيات}

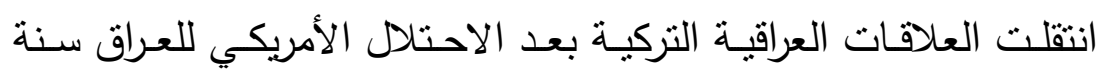

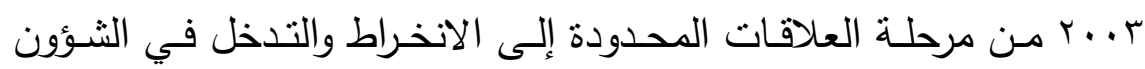

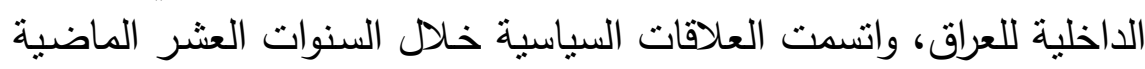

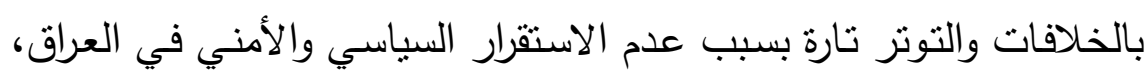

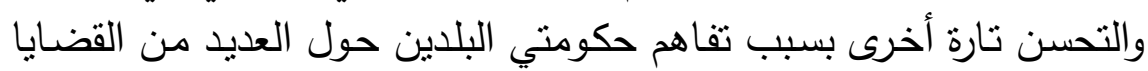

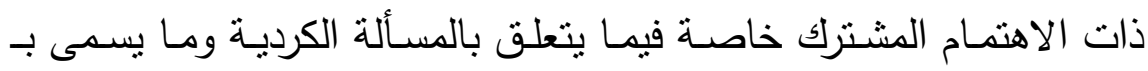
(الإرهاب) والأمن الإقليمي والنفط.

وفيما يخص السياسة الخارجية تجاه العراق يمكن القول إن تركيا انتهجت

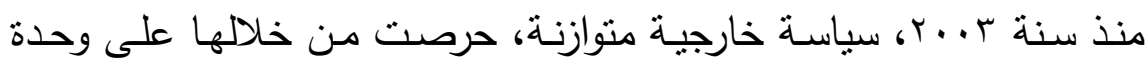

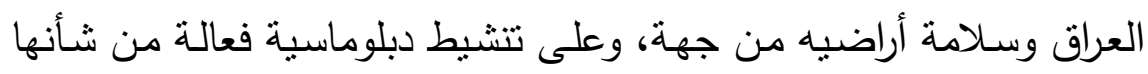

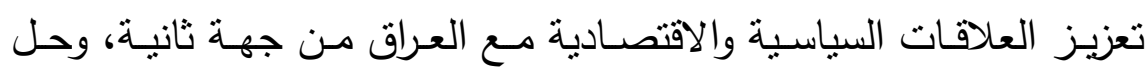

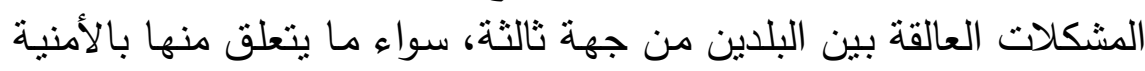

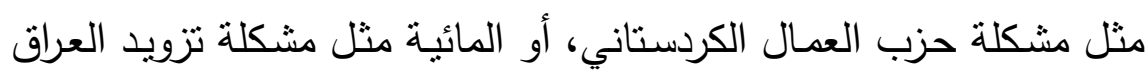




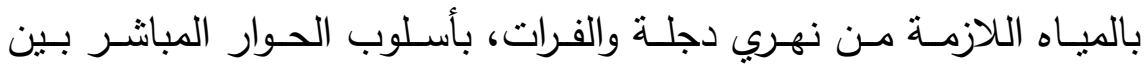

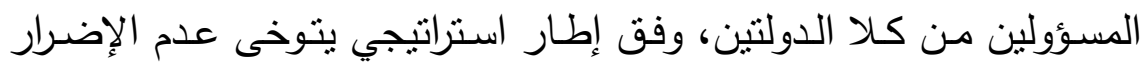

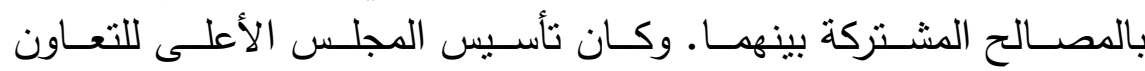

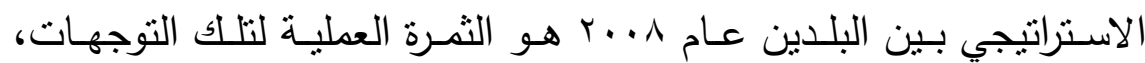

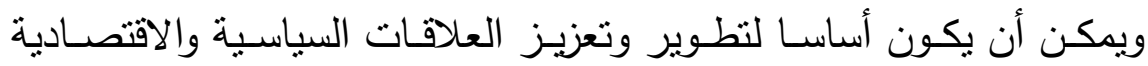
والأمنية بين البلدين في المستقبل وصولاً إلى مرحلة الثراكة الإستراتيجية.

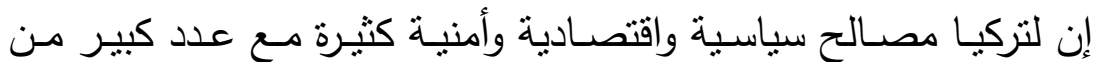

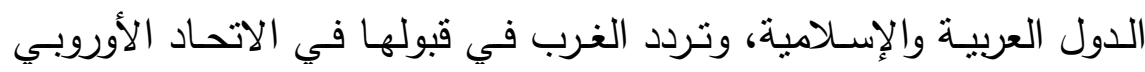

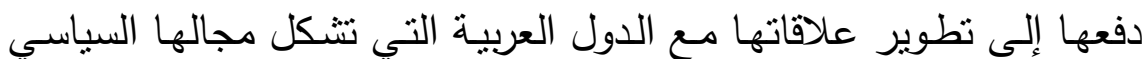
والاقتصادي الحيوي، لهذا فان سياستها الخارجية تركز على تمتين التين علاقاتها

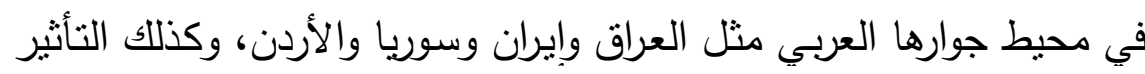

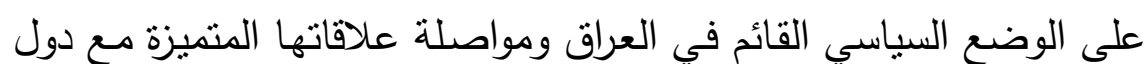

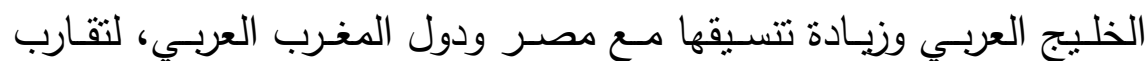

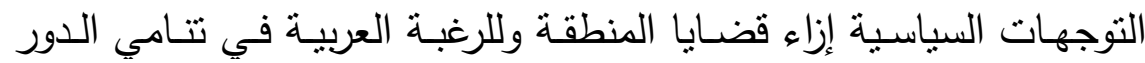
الإقليمي لتركيا في المنطقة مقابل النفوذ الإيراني. بناءاً على ما سبق يمكن الإثنارة إلى أبرز الإنتتاجات النيات ونوصيات البحث كما يلي: ناء

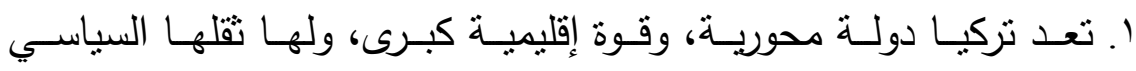

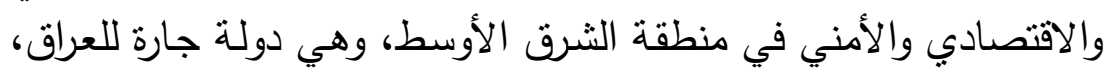

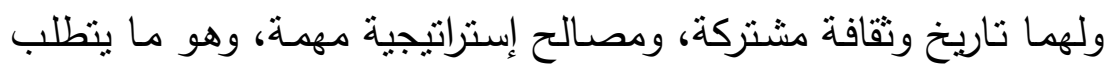

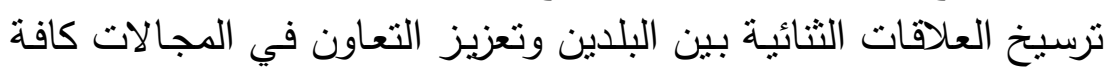

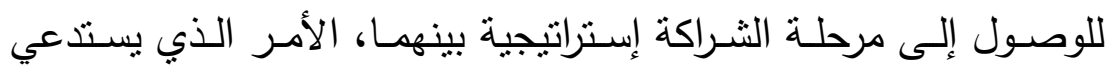

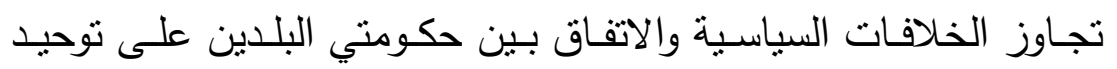
الجهود لإيجاد أجواء حوار بناء وتعاون مثمر لمواجهة المشكلات القائمة 


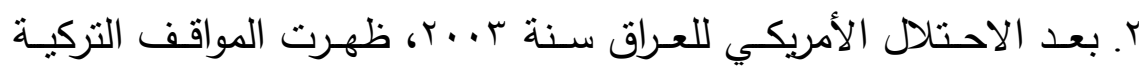

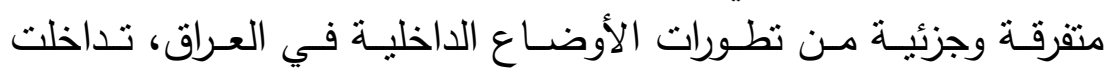

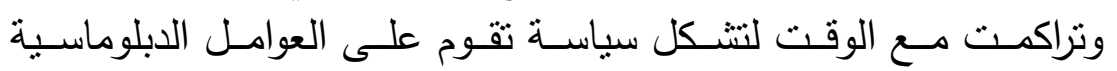

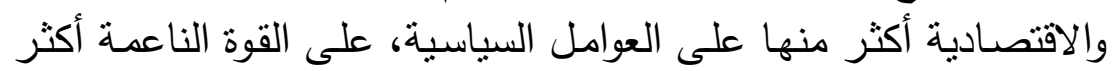

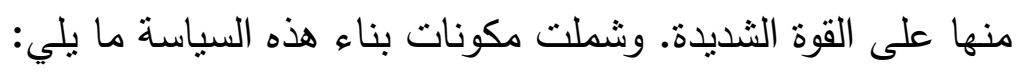

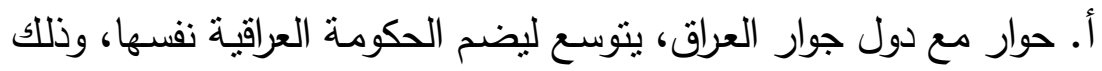

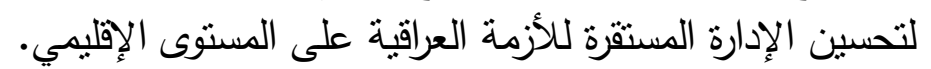

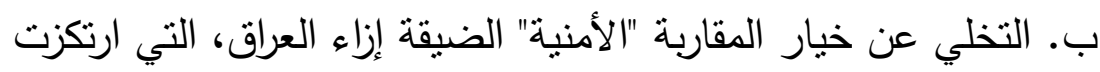

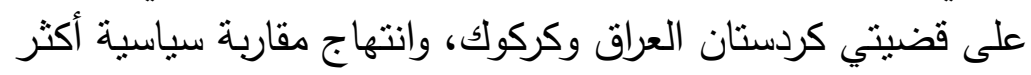
مرونة تجاه العراق تقوم على إستراتيجية التوازن. ت. تحسين العلاقات مع الأطراف السياسية الفاعلة في العراق بمان فئنة فيها الأحزاب الكردية.

جـ. الابتعـاد قليلا عن سياسـة تتسم بمشـاكل إثثيـة وعرقية إزاء الأقليـة

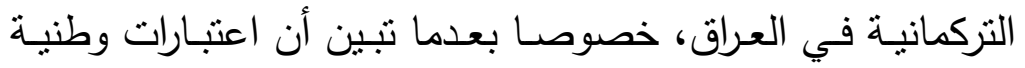

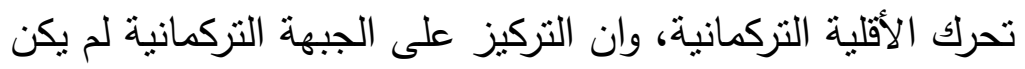
في محله مطلقاً.

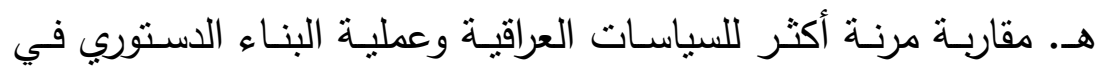
العراق الجديد، كانت حصيلتها ظهور استعداد أكثر لاى أنقرة لقبول

$$
\text { الصيغة الفيدرالية للعراق. }
$$

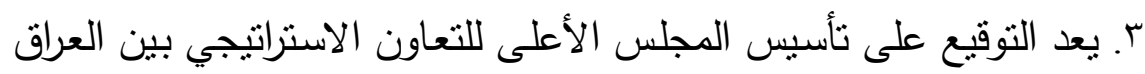

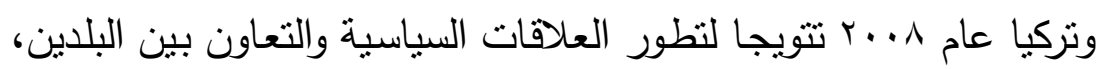

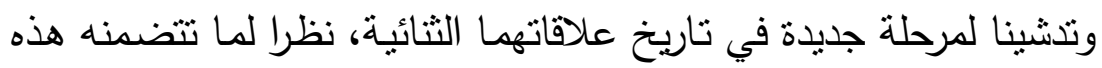

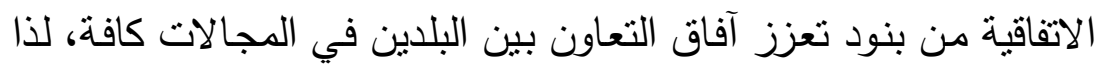

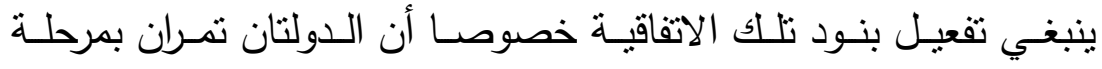
حساسة ودقيقة وسط عاصفة من التغييرات في المنطقة. 
؛. يلاحظ أن الخط البياني للعلاقات العراقية النركية شهد تراجعا ملفتاً خلال

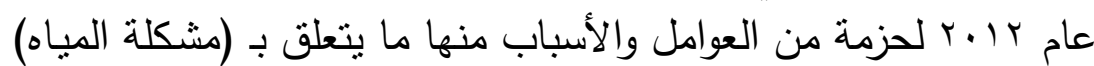

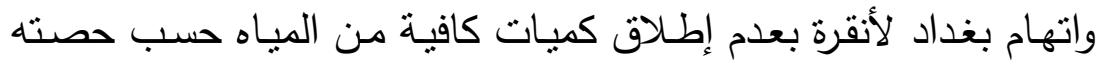
التي تحددها القواعد الدولية، ومشكلة (زيارة وزير الخارجية التركي إلى بلى التياه

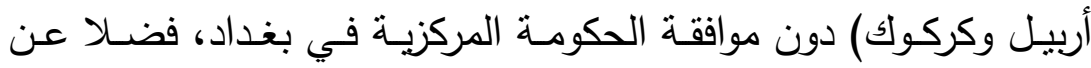

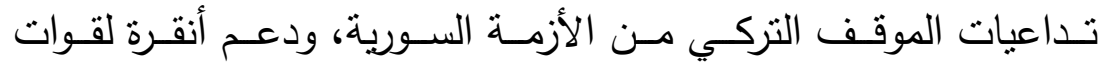

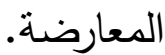

ه. فيما يتعلق بسياسة تركيا تجاه العراق خلال السنوات العشر الماضية لقد

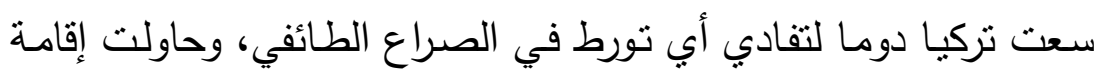

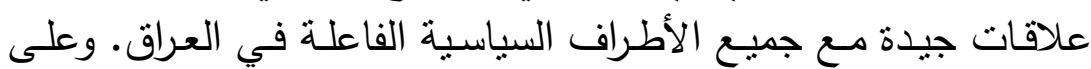

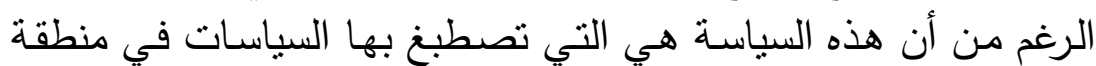

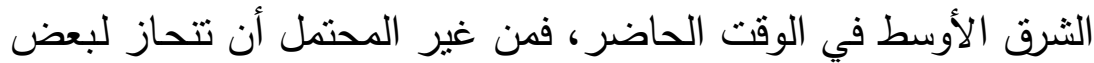

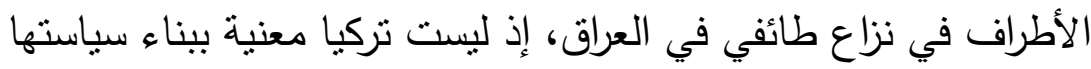

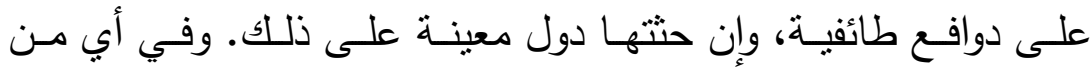

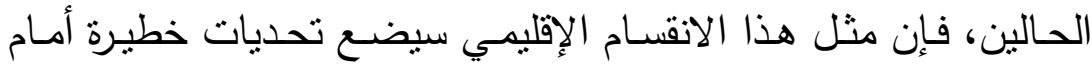

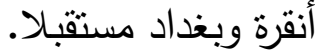
T. إن موقف العراق من الأزمة السورية والمعارض للموقف التركي زاد من

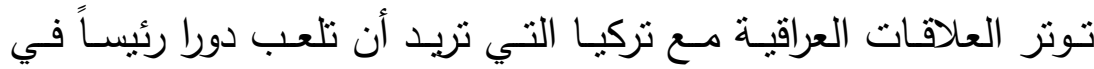

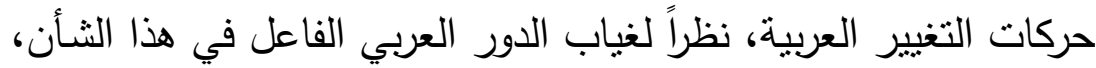

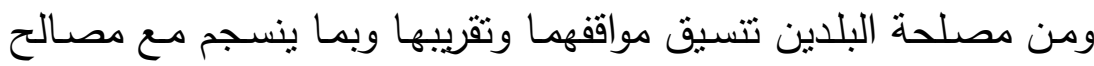

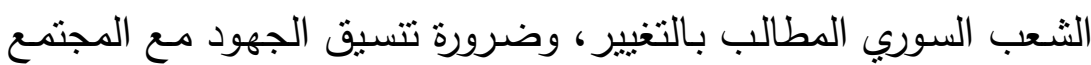
الدولي لحل الأزمة السورية. 7. وجوب أن ينتهج العراق سياسة خارجية وطنية مستقلة بعيدة عن الأجندة

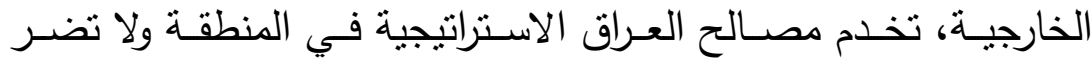
بعلاقاتها مع دول الجوار، وإن تعدد المصادر في رسم السياسة الخارجية النافية

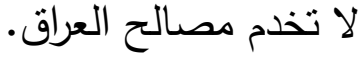


8. إن حـل الخلافـات السياسـية الداخليـة في العـراق كفيـل باسـتقرار العـراق

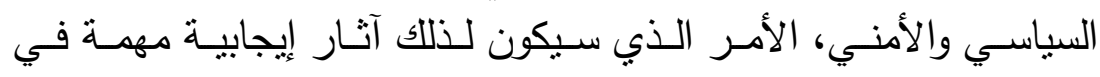
تحصين العراق من الانقسامات وتعزبز جبهته الداخلية، وتحسين صورته الامئه الخارجية، ليتمكن من ممارسة دوره الفاعل في المنطقة كقوة إقليمية مؤثزة الأفئ

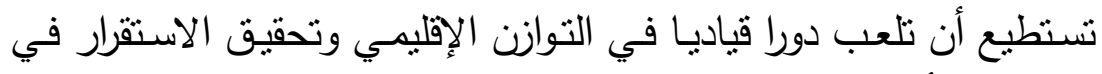

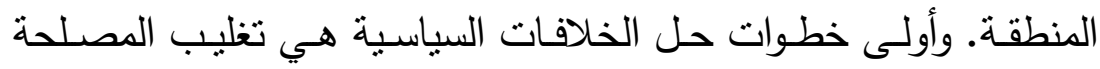

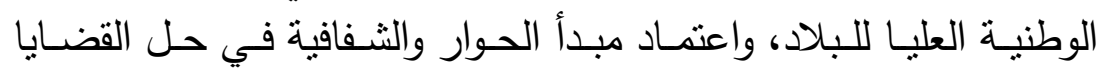
الخلافية، وعدم ارتباط الأحزاب السياسية بأجندة خارجية.

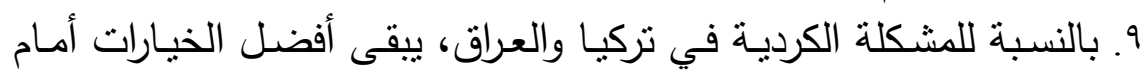

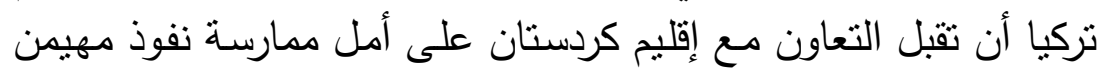

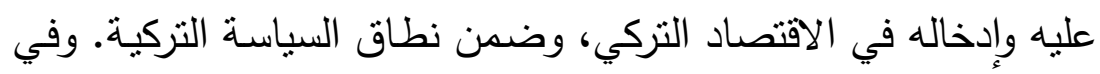
نهايـة المطاف، فإن حل المشكلة الكرديـة في تركيا هو الطريت وفئ الوحيد

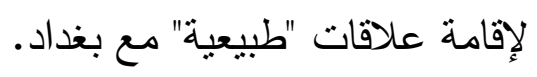

\title{
Iraqi - Turkish Relations
}

2002-2012

\section{Dr. Lugman O. Mahmoad Alnuaing Prof. Assistant/ Regional Studies Center Univessity of Mosul}

\begin{abstract}
This research deals with the subject of Iraqi-Turkish relations during the period between (2002-2012), this period constitute a crucial stage in the history of relations between the two countries which had witnessed an internal developments in each of them, in Turkey, the coming of justice and Development Party (AKP) to power in late 2002 represents a new phase in the Turkey's contemporary history and
\end{abstract}


in its internal and external policy, regional and international relations, while Iraq has offered the U.S. occupation in 2003, which affected in its political, security, economic situation and in its regional and international relations which reflected on the bilateral relations between the two states.

\section{هوامش البحث ومصادره}

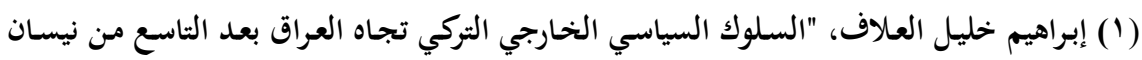

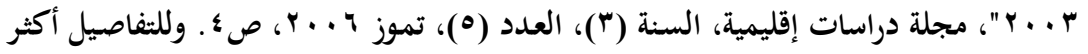

(๕) للتفاصيل أنظر: أحمد نوري النعيمي، العلاقات العراقية-التركية: الواقع والمستقبل، ط \إعمان:

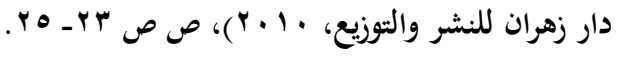




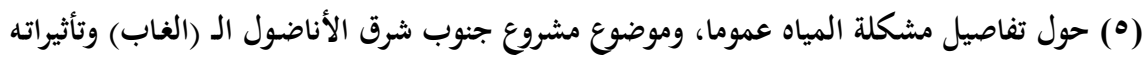

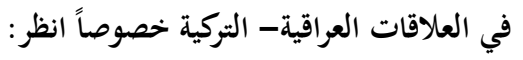

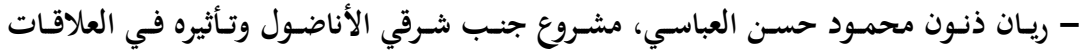

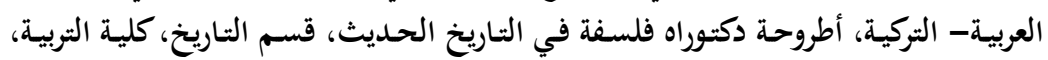

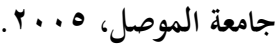

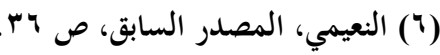

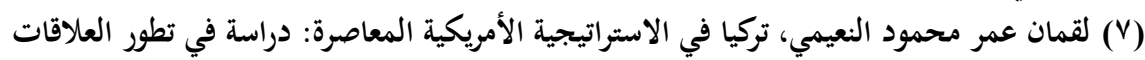

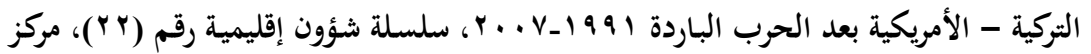

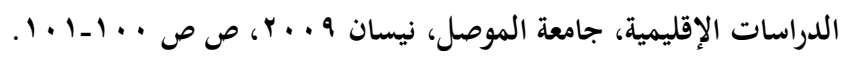

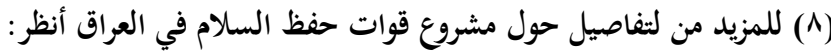

- Marc Crossman, "The U.S.- Turkish Partnership", The DISAM Journal, Winter 2004-2005, PP. 68-69.

(9) العلاف، "السلوك السياسي الخارجي التركي تجاه العراق ..."، المصدر السابق، ص ص VI VI .

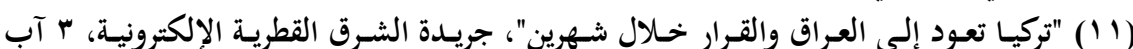

r...r

-http://www.al-sharq.com/DisplayColArticles.aspx?CurrentPage=0\&id=\&cid=

drmohammednoordhin

$$
\begin{aligned}
& \text { (r) (1) المصدر نفسه. }
\end{aligned}
$$

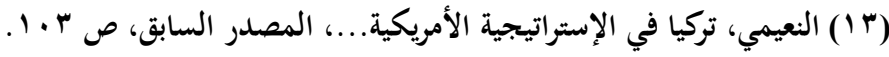

$$
\begin{aligned}
& \text { (\& (1) المصدر نفسه. }
\end{aligned}
$$

(15) "Nazli Gensoy \& Brock Dahl, Chronology of U. S.- Turkish Relations: July 2002- January 2004, Washington Institute, Washington D.C., 2004, p.70.

(16) Ibid, p.72.

(17) Ibid, p.77.

(18) Ibid, pp. 79-80.

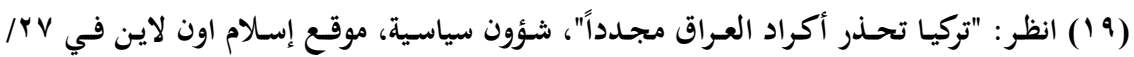

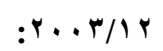

- http:// www.islamonline.net/arabic/news/2003-12/27/article 05.htm 


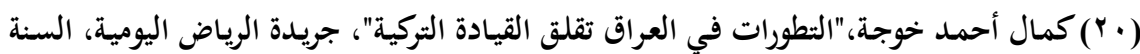

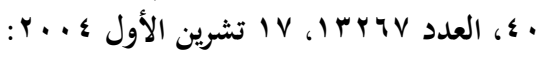

-http://www.alrivadh.com/Contents/17-10-2004/Mainpage/POLITICS_28893.php\#TopPage

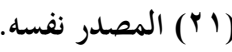

$$
\begin{aligned}
& \text { (YY) (Y ) المصدر نفسه. } \\
& \text { (YT) }
\end{aligned}
$$

(24) See: - Michael Rubin, "A Comedy of Errors: American-Turkish Diplomacy and Iraq War", Turkish Policy Quarterly, Vol.4, No.1, Spring 2005, p.9:

-http://www.esiweb.org/pdf/esi-turkey-tpq-id-18-pdf

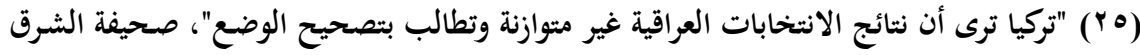

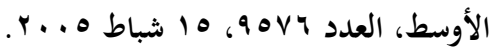

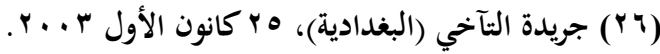$$
\text { (YV) }
$$

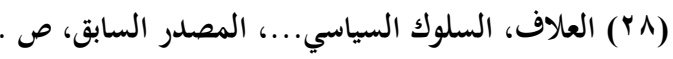

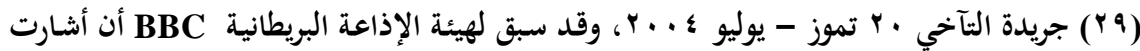

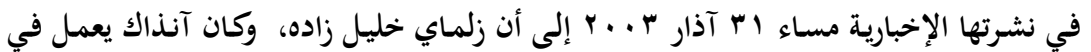

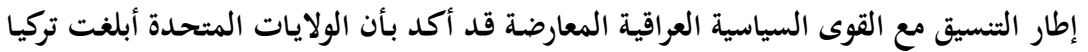

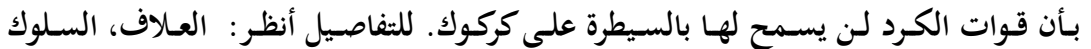

$$
\text { السياسي....، المصدر السابق، ص } 7 .
$$

(†) موقف أنقرة من أزمات المنطقة المتفجرة"، برنامج حوار مفتوح، موقع قناة الجزيرة الفضائية،

$$
\text { : r. . T/r/r }
$$

-http://www.aljazeera.net/NR/exeres/4E670C50-91E5-4E23-805C-CBAFF8275B3\#L1

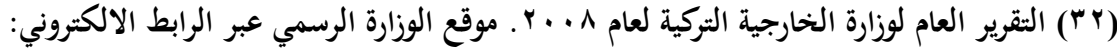

- http://www.mfa.gov.tr/data/DISPOLITIKA/Arapcasynopsis2008.pdf

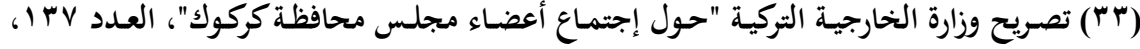

$$
\text { : r. . N/V/r }
$$

- http://www.mfa.gov.tr/137_31-7-2008_ar.mfa 
دراسات إقليمية • 1 (r)

- Henri J. Barkey, " Turkey's New Engagement in Iraq", Special Report No. 237, United States Institute of Peace, May 2010, pp3-4.

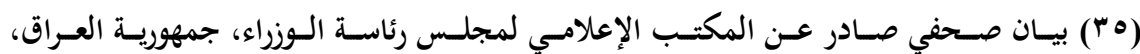
$: r+V / \Lambda / V$

- http://nahrain.com/d/news/07/08/08/nhr0808c.html

$$
\begin{aligned}
& \text { ( ("r) المصدر نفسه. }
\end{aligned}
$$

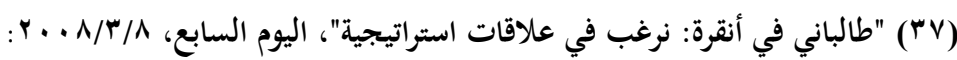

- http://www.youm7.com/News.asp?NewsID=18251\&SecID=88\&IssueID=0

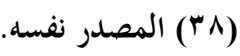

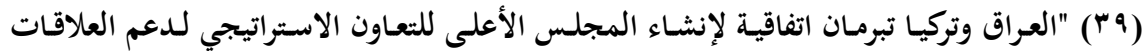

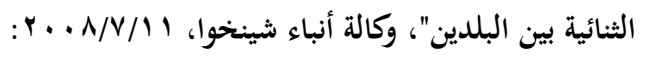

-http://www.arabic.xinhuanet.com/arabic/2008-07/11/content_668135.htm

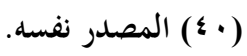

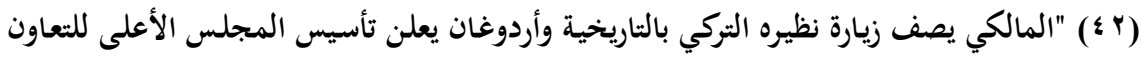

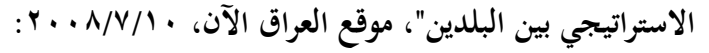

-http://iraqalaan.com/bm/Politics/3586.shtml

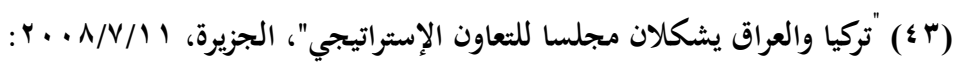

-www.aljazeera.net/NR/EXERES/4CD6FCCC-630D-4A28-9853-0D71CE8BE2B9. htm

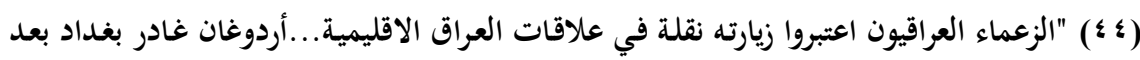

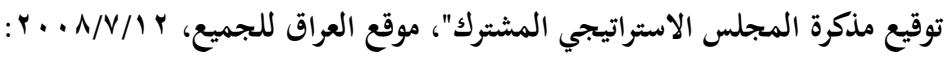

-http://www.iraq4allnews.dk/new/ShowNews.php?cat=6\&id=7523

$$
\text { ( ) ( }
$$

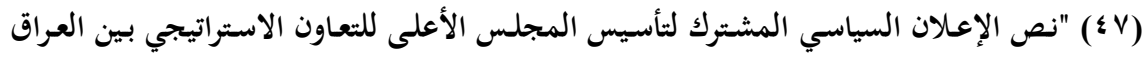

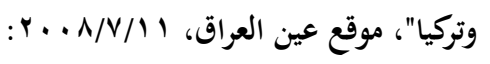

- www.eyeiraq.com/show/10671.html

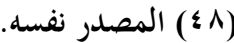

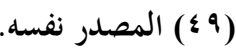

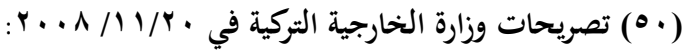

- http://www.mfa.gov.tr/default.ar.mfa 
(10) "زيباري يصل انقرة لبحث العلاقات الثنائية بين العراق وتركيا وسبل تعزيزها"، الوكالة الوطنية

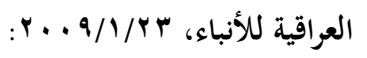

- http://www.ninanews.com/Arabic/News_Details.asp?ar95_VQ=EGFGDL

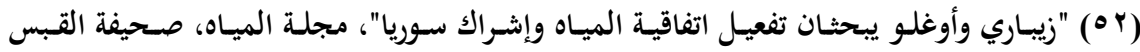

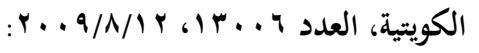

- http://www.alqabas.com.kw/Article.aspx?id=524747\&date=12082009

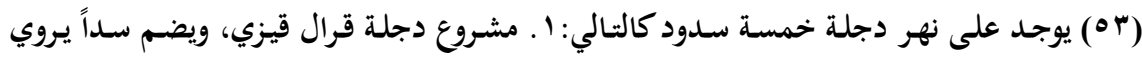

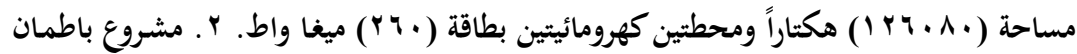

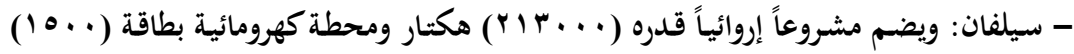

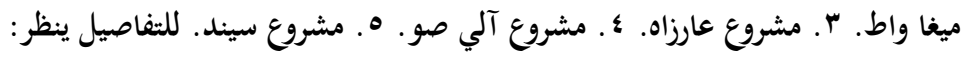

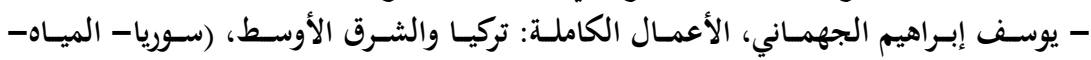

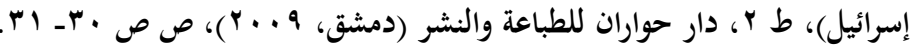

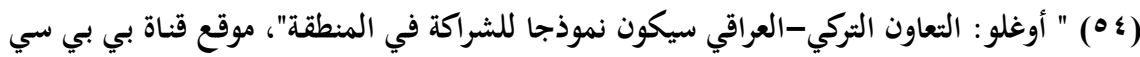

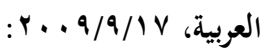

- http://www.bbc.co.uk/arabic/middleeast/2009/09/090917_dh_turkey_iraq_tc2.shtml

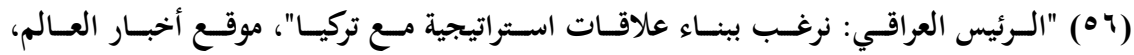

$$
\text { : r. 1./1./1r }
$$

- http://www.akhbaralaalam.net/news_detail.php?id=41256

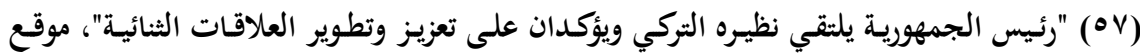

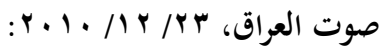

- http://sotaliraq.com/iraq-news.php?id=13091

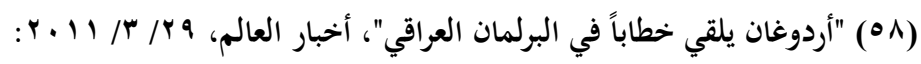

- http://www.akhbaralaalam.net/news_detail.php?id=44890

(ه9 ) "رئيس الجمهورية يؤكد أهمية تعزيز العلاقات العراقية-التركية"، مكتب إعلام الاتحاد الوطني

- http://www.pukmedia.com/iraq/18180-2011-07-06-16-36-51

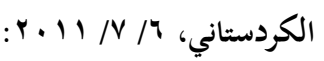

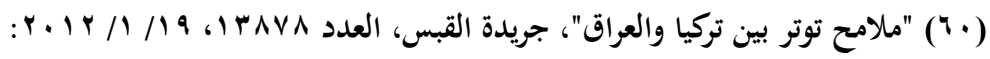

- http://www.alqabas.com.kw/ArticlePrint.aspx?id=764380\&mode=print 
دراسات إقليمية • 1 (r)

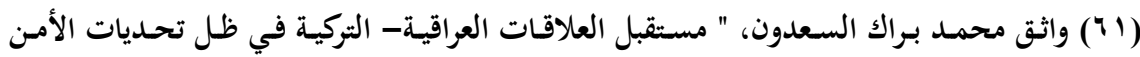

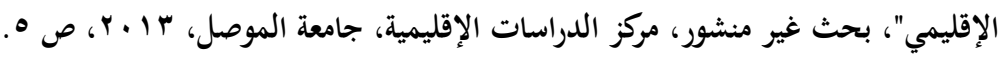

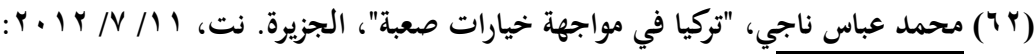

-http://www.aljazeera.net/analysis/pages/978d5936-b6db-4281-80e8-0c53c1a17f91

(r)

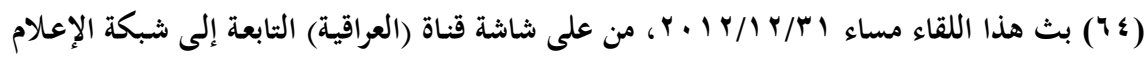

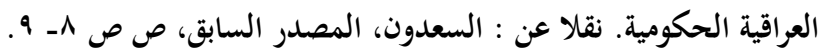

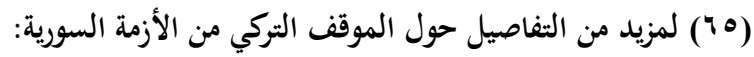

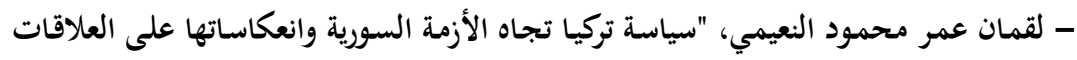

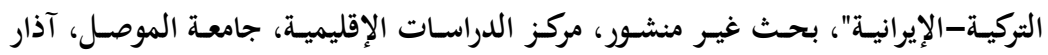

$r+1 r$

- علي حسين باكير، محددات الموقف الثركي من الأزمة السورية: الأبعاد الآنية والانعكاسات

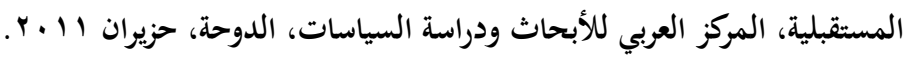

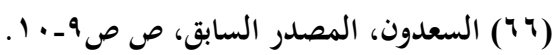

